\author{
UNIVERSIDADE DE SÃO PAULO \\ ESCOLA DE ENGENHARIA DE SÃO CARLOS \\ DEPARTAMENTO DE ENGENHARIA DE PRODUÇÃO
}

PAOLA STEFANELLI

\title{
Modelo de Programação da Produção Nivelada para Produção Enxuta em Ambiente ETO com Alta Variedade de Produtos e Alta Variação de Tempos de Ciclo
}

São Carlos

2010 



\section{Modelo de Programação da Produção Nivelada para Produção Enxuta em Ambiente ETO com Alta Variedade de Produtos e Alta Variação de Tempos de Ciclo}

Dissertação apresentada ao Programa de PósGraduação em Engenharia de Produção, da Escola de Engenharia de São Carlos, da Universidade de São Paulo (EESC-USP), como parte dos requisitos para obtenção do título de Mestre em Engenharia de Produção.

Área de concentração: Processos e Gestão de Operações

Orientador: Prof ${ }^{\mathrm{o}}$ Associado Antonio Freitas Rentes

São Carlos 
AUTORIZO A REPRODUÇÃO E DIVULGAÇÃO TOTAL OU PARCIAL DESTE TRABALHO, POR QUALQUER MEIO CONVENCIONAL OU ELETRÔNICO, PARA FINS DE ESTUDO E PESQUISA, DESDE QUE CITADA A FONTE.

Ficha catalográfica preparada pela Seção de Tratamento da Informação do Serviço de Biblioteca - EESC/USP

Stefanelli, Paola
S816m Modelo de programação da produção nivelada para produção enxuta em ambiente ETO com alta variedade de produtos e alta variação de templos de ciclo / Paola Stefanelli ; orientador Antonio Freitas Rentes. -- São Carlos, 2010.

Dissertação (Mestrado-Programa de Pós-Graduação em Engenharia de Produção e Área de Concentração em Processos e Gestão de Operações) -- Escola de Engenharia de São Carlos da Universidade de São Paulo, 2010.

1. Manufatura enxuta. 2. Produção por encomenda. 3. Estudo de tempo na produção. I. Título. 
FOLHA DE JULGAMENTO

Candidato(a): Engenheiro de Produção Mecânica PAOLA STEFANELLI.

Dissertação defendida e julgada em 17.01.2011 perante a Comissão Julgadora:

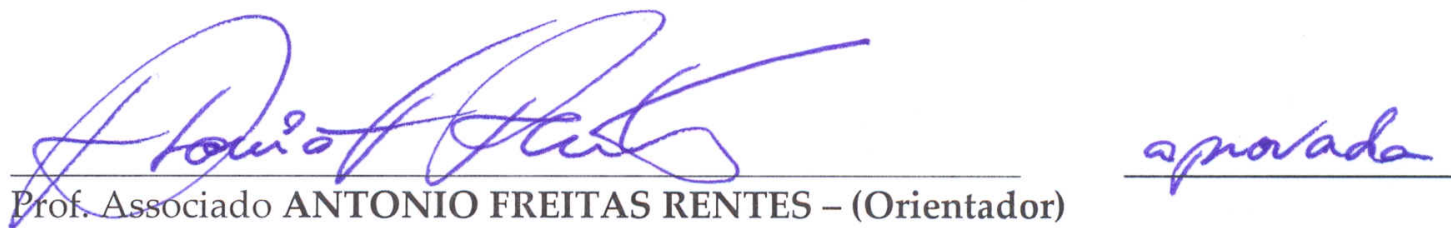

(Escola de Engenharia de São Carlos/USP)

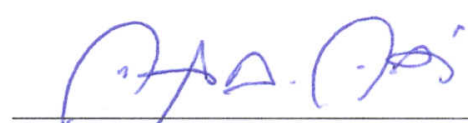

Aprevado

Prof. D . MARCEL ANDREOTTI MUSETTI (Escola de Engenharia de São Carlos/USP)

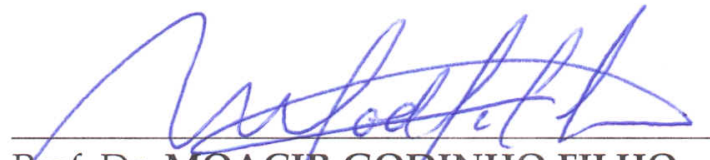

Prof. Dr. MOACUR GODINHO FILHO

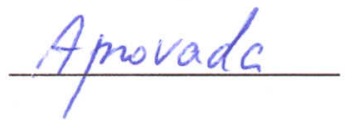

(Universidade Federal de São Carlos/UFSCar)

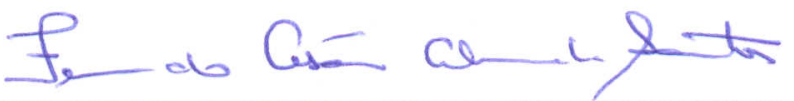

\begin{tabular}{c|c} 
Prof. Associado AQUILES ELIE GUIMARÃES KALATZIS \\
Coordenador do Programa de Pós-Graduação em
\end{tabular}

Engenharia de Produção

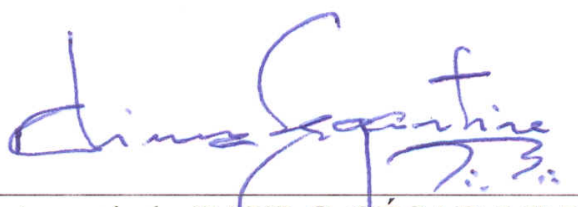

Prof. Associado PAULO CÉSAR LIMA SEGANTINE Presidente da Comissão de Pós-Graduação da EESC 


\section{AGRADECIMENTOS}

Agradeço primeiramente à minha família, especialmente meus pais e minha irmã, pelo apoio incondicional, amor, carinho e compreensão durante todos os passos da minha vida que contribuíram para o que sou hoje.

Agradeço também aos meus tios, tias, avós e primos pelos momentos de alegria, conforto, amizade e carinho que minha família me proporciona.

Agradeço ao Prof. Dr. Antonio Freitas Rentes pela orientação, esforço e exemplo de vontade mesmo nos momentos mais difíceis desse trabalho e por me encorajar quando obstáculos apareceram.

Agradeço ao Prof. Dr. Moacir Godinho Filho e ao Prof. Dr. Marcel Andreotti Musetti pelas valiosas contribuições durante a qualificação e defesa deste trabalho.

Agradeço aos amigos da Hominiss Consulting por todo companheirismo, aprendizado e amizade. Em especial, agradeço a três pessoas que foram muito importantes para a conclusão desse trabalho: Thiago Silva, José Geraldo e Ricardo Nazareno.

Agradeço aos meus amigos por viverem comigo os momentos alegres e estarem ao meu lado nos momentos mais difíceis. Agradeço mesmo àqueles amigos que, por um motivo ou outro, estão distantes fisicamente, mas que sempre são lembrados com muito carinho.

Enfim, a todos que reconhecem o meu esforço e aos que influenciaram minha formação acadêmica e enriqueceram, a cada dia, minha caminhada pessoal e profissional, o meu "Muito obrigada!". 


\section{RESUMO}

STEFANELli, P. (2010). Modelo de Programação da Produção Nivelada para Produção Enxuta em Ambiente ETO com Alta Variedade de Produtos e Alta Variação de Tempos de Ciclo. Dissertação (Mestrado) - Escola de Engenharia de São Carlos, Universidade de São Paulo, São Carlos, 2010.

A Produção Enxuta vêm exercendo um papel cada vez mais importante durante as transformações das organizações em busca de competitividade no mercado. O nivelamento de produção surge como uma das mais importantes características da Produção Enxuta. O ambiente de produção com alta variedade de produtos, tipologia de produção Engineer to Order e com alta variação de tempo de ciclo está se tornando cada vez mais significativo no mercado atual e possui as mesmas necessidades de nivelamento da produção que os ambientes de produção nos quais tradicionalmente são aplicados os conceitos de Produção Enxuta. Este trabalho propõe um modelo de programação nivelada da produção para o tipo de ambiente de produção citado e descreve uma aplicação utilizando o método apresentado em uma empresa de vidros para a construção civil.

Palavras-chave: Produção Enxuta, Produção sob Encomenda, Nivelamento de Produção, Alta Variação de Tempos de Ciclo 


\section{ABSTRACT}

STEFANELLI, P. (2010). Leveled Production Programming Model for Lean Production in ETO Environment with High Variety of Products and High Variation of Cycle Times. Dissertação (Mestrado) - Escola de Engenharia de São Carlos, Universidade de São Paulo, São Carlos, 2010.

Lean Production has played an increasingly important role in the transformation of organizations for market competitiveness. The production leveling appears as one of the most important characteristics of Lean Production. The production environment with high variety of products, production typology Engineer to Order, with high variation of cycle time is becoming increasingly significant in today's market and has the same needs leveling production environments in which traditionally applied the concepts of Lean Production. This paper proposes a programming model of the production level for the kind of production environment cited and describes an application using the method presented in a glass company for civil construction.

Keywords: Lean Production, Engineer to Order, Production Leveling, High Variation of Cycle Times 


\section{LISTA DE FIGURAS}

Figura 1 - Esquema sobre as fases de trabalho 24

Figura 2 - Aumento dos Lucros na Produção em Massa e na Produção Enxuta 29

Figura 3 - Composição das atividades e os enfoques da Produção Enxuta e Produção em Massa Fonte: Adaptado de HINES e TAYLOR (2000) 31

Figura 4 - Redução dos estoques e a exposição dos problemas da produção 33

Figura 5 - Exemplos de definição do processo puxador. 38

Figura 6 - Nivelamento do mix de produção no processo puxador 39

Figura 7 - Significado de "toda parte toda..." ou TPT 40

Figura 8 - Etapas de mapeamento do fluxo de valor 42

Figura 9 - Ícones para Mapeamento do Fluxo de Valor . 42

Figura 10 - Ícone para representação de processos compartilhados em um MFV 43

Figura 11 - Exemplo de um mapa de fluxo de valor 43

Figura 12 - Funcionamento do sistema kanban . 50

Figura 13 - Diferença entre a abordagem tradicional (sistema empurrado) e o sistema puxado

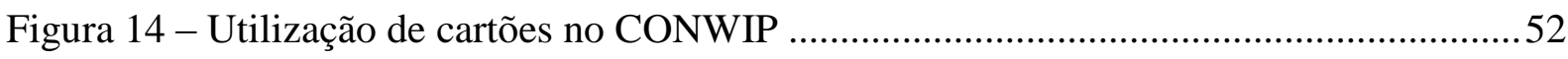

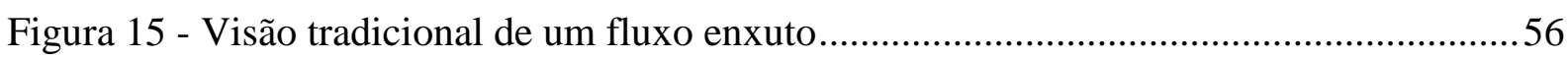

Figura 16 - Modelo de quadro de nivelamento da produção ................................................62

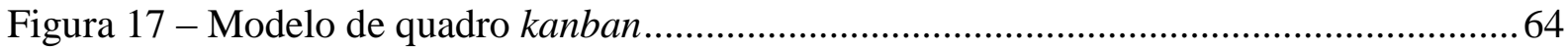

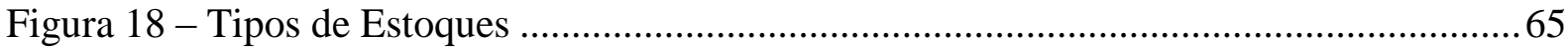

Figura 19 - Cálculo de dimensionamento de supermercados .................................................. 66

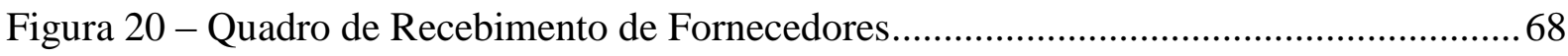

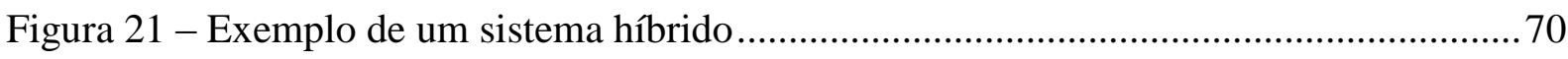

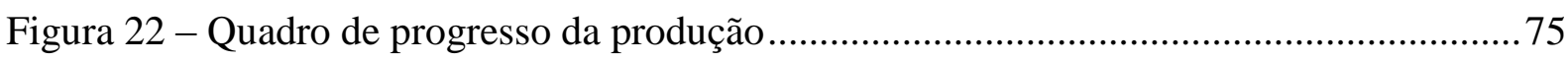

Figura 23 - Modelo de quadro de nivelamento de produção ................................................. 77 
Figura 24 - Modelo de quadro de nivelamento da produção proposto por Tardin (2001) ...... 78

Figura 25 - Estrutura do modelo de nivelamento da produção proposto por Araujo (2009) .. 80

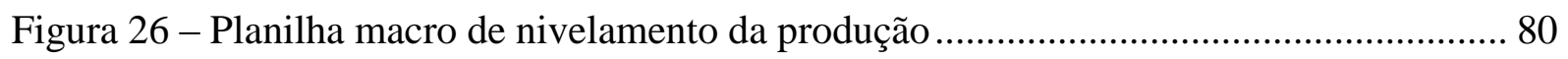

Figura 27 - Detalhe da planilha de nivelamento da produção .............................................. 81

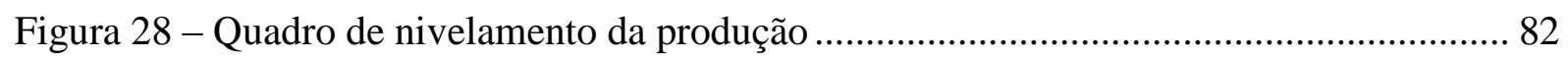

Figura 29 - Situações de posicionamento do RRC no fluxo de valor ..................................... 89

Figura 30 - Procedimento de programação e nivelamento do processo puxador para a

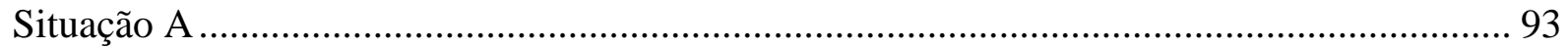

Figura 31 - Procedimento de programação e nivelamento do processo puxador para a Situação B

Figura 32 - Procedimento de programação e nivelamento do processo puxador para a

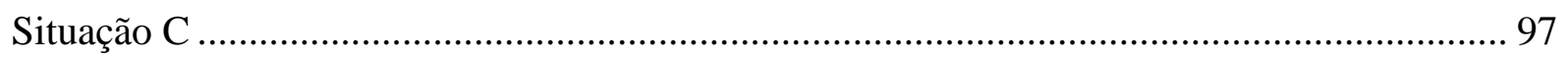

Figura 33 - Procedimento de programação e nivelamento do processo puxador para a

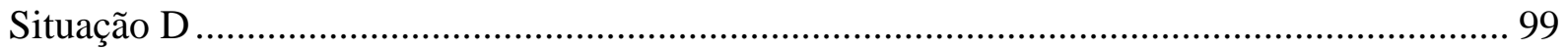

Figura 34 - Mapa de Fluxo de Valor para a situação anterior às implantações .................... 104

Figura 35 - Mapa de Fluxo de Valor referente à situação esperada após as implantações ... 104

Figura 36 - Programação do processo de Laminação.......................................................... 113

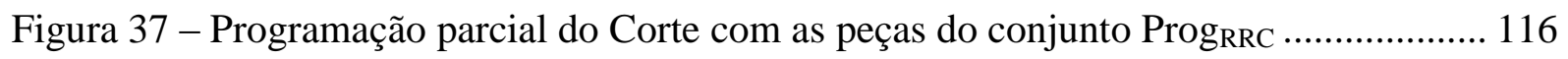

Figura 38 - Programação do processo de Corte .................................................................. 117

Figura 39 - Quadro de programação do processo de Corte ................................................... 118

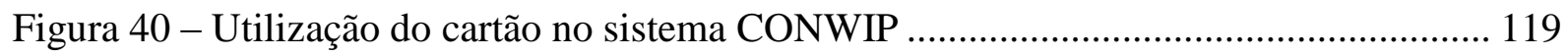




\section{LISTA DE GRÁFICOS}

Gráfico 1 - Nível de estoque em uma produção não-nivelada................................................58

Gráfico 2 - Nível de estoque em uma produção nivelada a cada 2 horas ..............................59

Gráfico 3 - Evolução da produção diária por turno no processo de Laminação.....................121 


\section{LISTA DE TABELAS}

Tabela 1 - Critérios para classificação de pesquisas e as possíveis classificações. 22

Tabela 2 - Causas e Soluções para os Tipos de Desperdícios................................................ 35

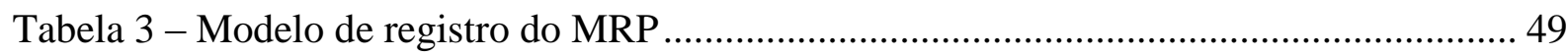

Tabela 4 - Exemplo de takt time para produtos com variação de tempo de ciclo ................... 72

Tabela 5 - Relação entre características de um modelo de programação nivelada da produção

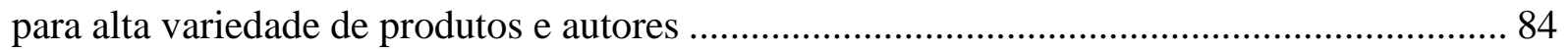

Tabela 6 - Estimativa de tempo de ciclo para vidros multilaminados................................. 107

Tabela 7 - Estimativa de tempo de ciclo para vidros laminados ......................................... 108

Tabela 8 - Estimativa em pontos dos tempos de ciclo para vidros multilaminados .............. 108

Tabela 9 - Estimativa em pontos dos tempos de ciclo para vidros laminados ...................... 109

Tabela 10 - Planilha de estimativa de tempos de ciclo para vidros laminados .................... 109 


\section{LISTA DE ABREVIATURAS E SIGLAS}

$\mathrm{AV}$ - Atividade que agrega valor

CONWIP - Constant Work in Process

CRP - Capacity Requeriments Planning

CTV - Custos totalmente variáveis

DO - Despesas operacionais

EPEI - Every part every interval

ETO - Engineer to order

FIFO - First in first out

$\mathrm{G}-$ Ganho

I - Inventário

JIT - Just in time

MFV - Mapa de fluxo de valor

MPS - Master Production Scheduling

MRP - Material requirements planning

MRP II - Manufacturing resource planning

MTO - Make to order

NAV - Atividades que não agregam valor

OPT - Optimized production technology 
PCP - Planejamento e controle da produção

PVB - Polivinil butiral

RRC - Recurso com restrição de capacidade

SAP - Sistema de administração da produção

SMED - Single minute exchange of die

TOC - Teoria das restrições

TPC - Tambor - pulmão - corda

TPM - Total productive maintenance

TPS - Sistema Toyota de produção

TPT - Toda parte toda

WIP - Work in process 


\section{SUMÁRIO}

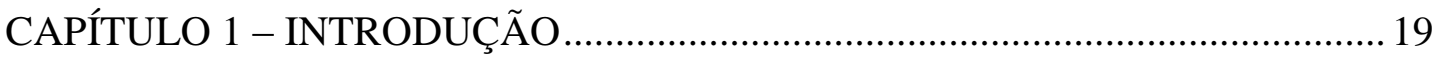

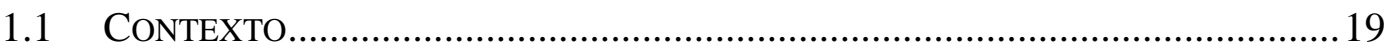

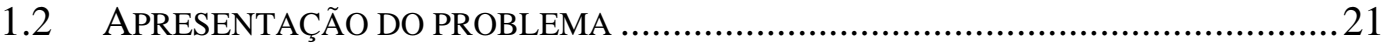

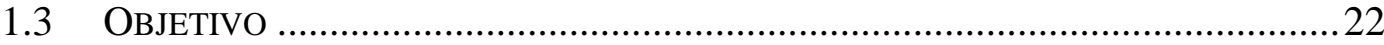

1.4 Metodologia DE PESQUiSA E DE DESENVOLVIMENTO DO TRABALHO ...........22

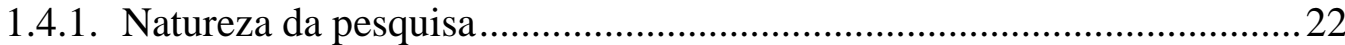

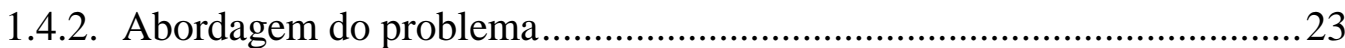

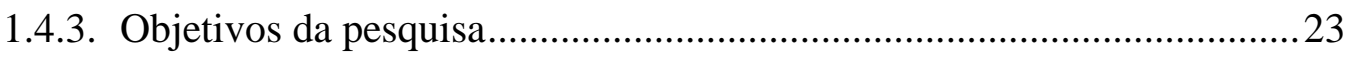

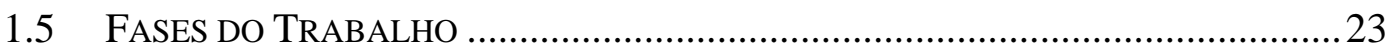

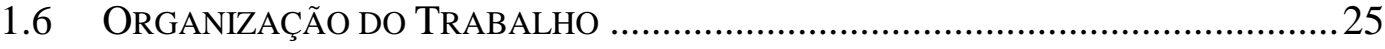

CAPÍTULO 2 - REVISÃO DA LITERATURA …................................................. 27

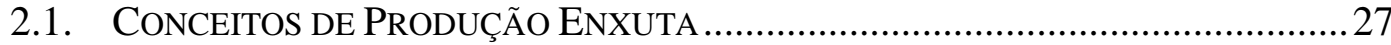

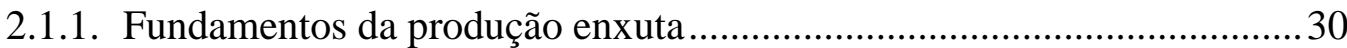

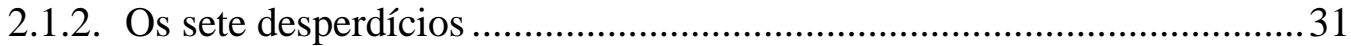

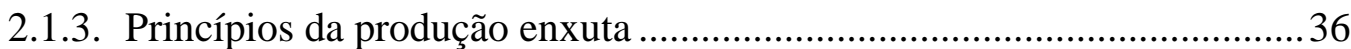

2.1.4. Recomendações para a Situação Futura ..................................................... 37

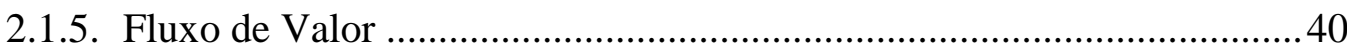

2.1.5.1. Mapeamento do Fluxo de Valor .......................................................4 41

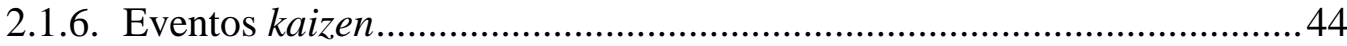

2.2. Planejamento E Controle da ProduÇão ................................................ 45

2.2.1. Programação e Controle da Produção ....................................................... 46

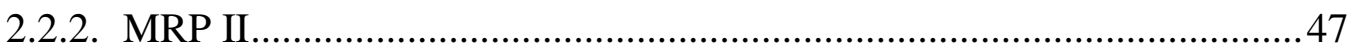

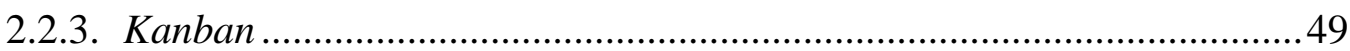

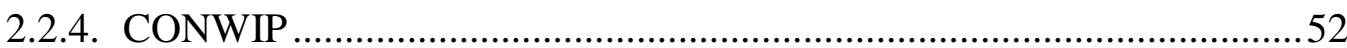

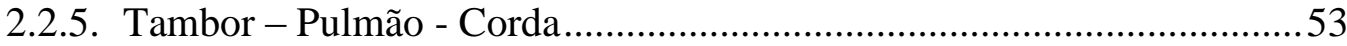


2.2.6. Programação da Produção em ambientes de Produção Enxuta .............. 55

2.2.7. Programação tradicional em ambientes de Produção Enxuta................. 55

2.2.7.1. Programação do Processo Puxador ................................................... 56

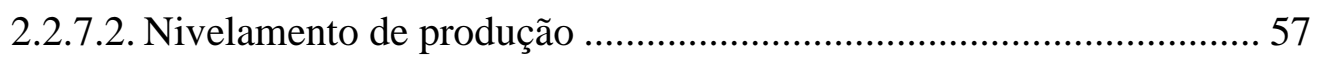

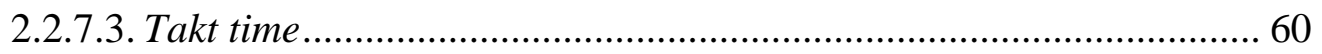

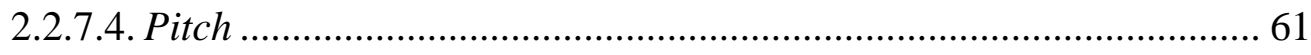

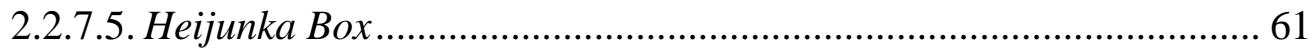

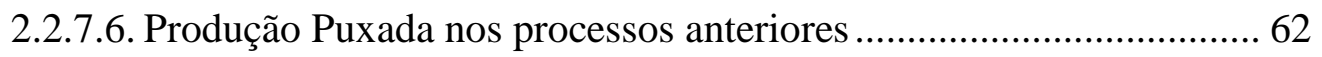

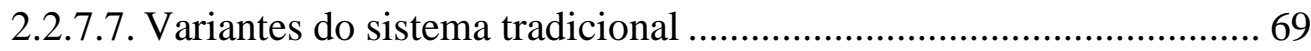

2.2.8. Nivelamento do processo puxador para ambientes de alta variedade de produtos $\quad 71$

2.2.8.1. Takt time para ambientes com alta variedade de produtos................ 71

2.2.8.2. Heijunka como ferramenta de programação .................................... 72

2.2.8.3. Modelos de programação nivelada da produção para ambientes com

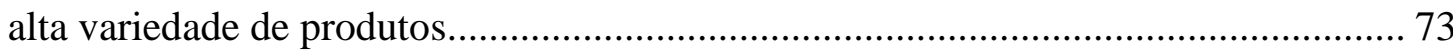

2.2.8.4. Nivelamento do processo puxador em ambiente ETO.................... 82

CAPÍTULO 3 - MODELO DE PROGRAMAÇÃO NIVELADA DA PRODUÇÃO85

3.1 NIVELAMENTO DO PROCESSO PUXADOR PARA AMBIENTE ENGINEER TO ORDER COM ALTA VARIEDADE DE PRODUTOS 85

3.1.1. Definição do takt time para ambientes com alta variação de tempos de ciclo $\quad 86$

3.1.2. Estimativa de tempo de ciclo do fluxo do puxador . 87

3.1.3. Situação de posicionamento do RRC no fluxo. 88

3.1.4. Procedimento de Programação do Processo Puxador de acordo com o posicionamento do RRC

CAPÍTULO 4 - APLICAÇÃO DO MODELO DE PROGRAMAÇÃO NIVELADA

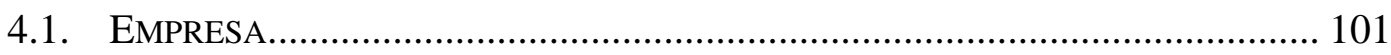

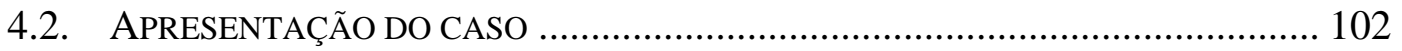

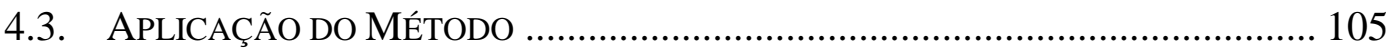

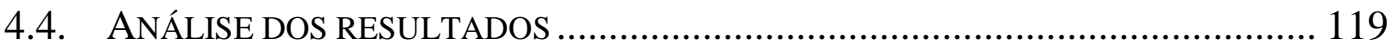

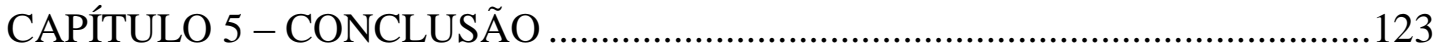




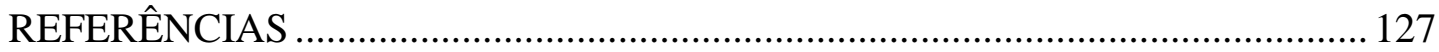




\section{CAPÍTULO 1 - INTRODUÇÃO}

\subsection{Contexto}

Diante da crescente competitividade existente em todas as empresas dos diferentes setores da economia, especialmente entre as empresas de manufatura, faz-se necessária a busca pelo melhor desempenho da empresa, através do aumento da produtividade e obtenção de vantagem competitiva em relação aos concorrentes. Segundo Gaither e Frazier (2002):

\footnotetext{
Para obter sucesso na competição global, as empresas dever ter um compromisso com a receptividade do cliente e com a melhoria contínua rumo à meta de desenvolver rapidamente produtos inovadores que tenham a melhor combinação de excepcional qualidade, entrega rápida e no tempo certo, e preços e custos baixos.
}

Melhorias no ambiente produtivo, com o objetivo de alcançar melhor desempenho, são foco de estudo há bastante tempo. Uma das principais formas de aplicação de métodos e ferramentas mais utilizadas pelas empresas atualmente para alcançar melhor desempenho é a Produção Enxuta, onde o objetivo é eliminar todo e qualquer tipo de desperdício (conforme será detalhado em capítulo posterior).

A Produção Enxuta surgiu no Japão após a Primeira Guerra Mundial nas fábricas da montadora de automóveis Toyota com o objetivo de possibilitar que essa empresa conseguisse sobreviver nesse ambiente pós-guerra e na característica do mercado japonês que demandava uma maior variedade de produtos e quantidades menores.

O desenvolvimento das ferramentas da Produção Enxuta foi de fundamental importância para a sobrevivência da montadora japonesa em uma época que os conceitos de produção em massa estavam sendo aplicados nos Estados Unidos com bons resultados. 
As empresas que buscam aplicar os conceitos de Produção Enxuta em seu sistema produtivo encontram alguns princípios e ferramentas a serem seguidos. Entre os princípios estão duas formas de encadeamento das operações do sistema produtivo: o fluxo contínuo e a produção puxada. O fluxo contínuo, que sempre que possível, deve ser priorizado em relação à produção puxada, é um fluxo de processos otimizado onde há uma quantidade muito baixa de estoques em processo e o lead time de processamento é bem próximo ao tempo de agregação de valor ao produto, representando o ideal que a empresa deve atingir em seus processos.

Porém, nem sempre é possível aplicar o fluxo contínuo e, nesses casos, há a produção puxada, que representa uma forma de ligar os processos a fim de um processo fornecedor fazer somente o que seu cliente está consumindo, ou seja, "puxando".

Para que uma empresa siga os princípios citados acima há um conceito fundamental que deve ser conhecido: o takt time. Esse conceito representa o ritmo que deve ser seguido para que a organização atenda a sua demanda. Esse fator é crítico para um planejamento e controle da produção em ambientes "enxutos".

Para um planejamento e controle da produção eficaz é importante que haja formas de nivelar a produção de maneira a minimizar os problemas causados pelo desnivelamento do fluxo de valor. A forma utilizada pela Toyota para operacionalizar o nivelamento da produção é o Heijunka box, um quadro para gerenciar visualmente a programação da produção nivelada.

Ambientes de produção que trabalham com a tipologia Engineer to Order, onde os produtos são desenvolvidos a partir das especificações do cliente, diferentemente dos ambientes onde tradicionalmente são aplicados os conceitos de Produção Enxuta, também podem se beneficiar com a aplicação do conceito de nivelamento de produção, por exemplo.

Os ambientes ETO representam uma parcela significativa dos segmentos da indústria no mercado atual, como bens de capital, produtos relacionados à construção civil, entre outros. 


\subsection{Apresentação do problema}

Segundo Smalley (2004), o nivelamento da produção é uma atividade crítica para garantir que os processos clientes obtenham exatamente o que precisam e quando precisam, enquanto tornam as atividades fornecedoras as mais eficientes possíveis. Tornar a produção nivelada é um dos grandes desafios das empresas que buscam aplicar os conceitos de Produção Enxuta, já que não há uma receita simples para criar o nivelamento de produção (SMALLEY, 2004).

O Heijunka box, que é a forma de operacionalizar o nivelamento de produção no chão de fábrica, é bastante utilizado nas empresas que aplicam os conceitos de Produção Enxuta.

Além da dificuldade em nivelar a produção, há outros fatores que tornam ainda mais complexa a implantação dos conceitos de produção enxuta nas empresas. Um desses fatores é a alta variedade de produtos que se torna cada vez mais comum na realidade das empresas devido às necessidades e desejos do mercado consumidor. Outro fator é a alta variação e o possível desconhecimento dos tempos de ciclo em um ambiente ETO.

Essa dissertação visa apresentar uma aplicação em um ambiente ETO com aplicação dos conceitos de produção enxuta e alta variedade de produtos com o objetivo de servir como base para um método de programação nivelada da produção.

Esse trabalho busca analisar, diante da bibliografia estudada sobre o assunto, quais as implicações e adaptações que devem ser realizadas em relação aos métodos existentes na literatura para os ambientes ETO com alta variedade de produtos e com variação de tempos de ciclo.

As questões de pesquisa para este trabalho são:

- Como definir takt time para ambientes de alta variedade de produtos, onde ocorrem variações nos tempos de ciclo?

- Como deve ser realizada a programação nivelada da produção para ambientes com alta variação de tempo de ciclo?

- Existe na literatura um método para nivelamento da produção para ambiente ETO com alta variedade de produto e alta variação de tempos de ciclo? 


\subsection{Objetivo}

O objetivo principal do trabalho é propor um modelo de programação nivelada da produção para ambientes de produção enxuta para ETO que apresentem alta variedade de produtos e alta variação de tempos de ciclo.

\subsection{Metodologia de pesquisa e de desenvolvimento do trabalho}

Uma pesquisa pode ser definida como um procedimento racional e sistemático que tem como objetivo proporcionar respostas aos problemas que são propostos. Uma pesquisa é importante quando não se dispõe de informação suficiente para responder ao problema, ou então quando a informação disponível se encontra em tal estado de desordem que não possa ser adequadamente relacionada ao problema (GIL, 1991). Segundo Silva e Menezes (2005) toda pesquisa deve ser classificada de acordo com alguns critérios como Natureza da pesquisa, Forma de abordagem do problema e Objetivos. Para cada critério citado existem algumas classificações para a pesquisa segundo o esquema mostrado na Tabela 1 e serão detalhados a seguir.

Tabela 1 - Critérios para classificação de pesquisas e as possíveis classificações

Critérios para Classificação de Pesquisas

\begin{tabular}{|c|c|}
\hline Natureza da & Pesquisa Básica \\
\cline { 2 - 2 } pesquisa & Pesquisa Aplicada \\
\hline $\begin{array}{c}\text { Abordagem do } \\
\text { problema }\end{array}$ & Pesquisa Quantitativa \\
\cline { 2 - 2 } & Pesquisa Qualitativa \\
\hline \multirow{2}{*}{ Objetivos } & Pesquisa Exploratória \\
\cline { 2 - 2 } & Pesquisa Descritiva \\
\cline { 2 - 2 } & Pesquisa Explicativa \\
\hline
\end{tabular}

A partir das classificações mostradas, a pesquisa aqui apresentada está classificada como:

\subsubsection{Natureza da pesquisa}

O trabalho aqui apresentado se enquadra em Pesquisa Aplicada onde, segundo Silva e Menezes (2005), possui o objetivo de gerar conhecimentos para aplicações práticas a fim de atingir a solução de problemas específicos. 
Este trabalho pode ser classificado como Pesquisa Aplicada, pois é uma aplicação prática de uma solução para um problema específico.

\subsubsection{Abordagem do problema}

O trabalho aqui apresentado se enquadra em Pesquisa Qualitativa. De acordo com Silva e Menezes (2005), neste tipo de pesquisa o pesquisador é o instrumento chave e o ambiente natural é a fonte direta para coleta de dados. A interpretação dos fenômenos e a atribuição dos significados são básicas e não necessita a utilização de métodos ou técnicas estatísticas.

Este trabalho pode ser classificado como Pesquisa Qualitativa, pois é baseado nas interpretações realizadas, a partir da percepção da pesquisadora, durante a aplicação prática, onde as análises acontecem de forma subjetiva.

\subsubsection{Objetivos da pesquisa}

O trabalho aqui apresentado se enquadra em Pesquisa Exploratória que, segundo Gil (2005), possui o objetivo de proporcionar familiaridade com o problema de forma a torná-lo mais explícito, construir hipóteses ou, ainda, aprimorar idéias. Na sua maioria, estas pesquisas assumem a forma de pesquisas bibliográficas ou estudos de caso.

Este trabalho pode ser classificado como Pesquisa Exploratória já que o objetivo do trabalho é explicitar um problema comum em alguns ramos da indústria e apresentar uma aplicação onde é implantada uma solução a esse problema discutido durante o trabalho.

\subsection{Fases do Trabalho}

Para atingir o objetivo proposto nesta pesquisa, há uma sequiência de atividades a serem executadas. A Figura 2 mostra um esquema com as atividades que serão executadas até o final da pesquisa. 
Primeiramente, o delineamento da pesquisa foi realizado, com a contextualização e a justificativa do problema, além da definição de quais as questões de pesquisa e os objetivos para este trabalho.

Após essa fase, foi realizado o estudo do material existente na literatura através da revisão bibliográfica sobre os temas mais relevantes para a pesquisa, com a análise das soluções encontradas na literatura para este problema apresentado e com a identificação de requisitos e características das soluções encontradas.

Além disso, foi apresentada e analisada uma aplicação do método (a partir dos requisitos e características das soluções encontradas na literatura). Por fim, foi apresentada uma proposta de um roteiro de aplicação deste método.

Todas as fases do trabalho citadas acima estão mostradas na Figura 1:

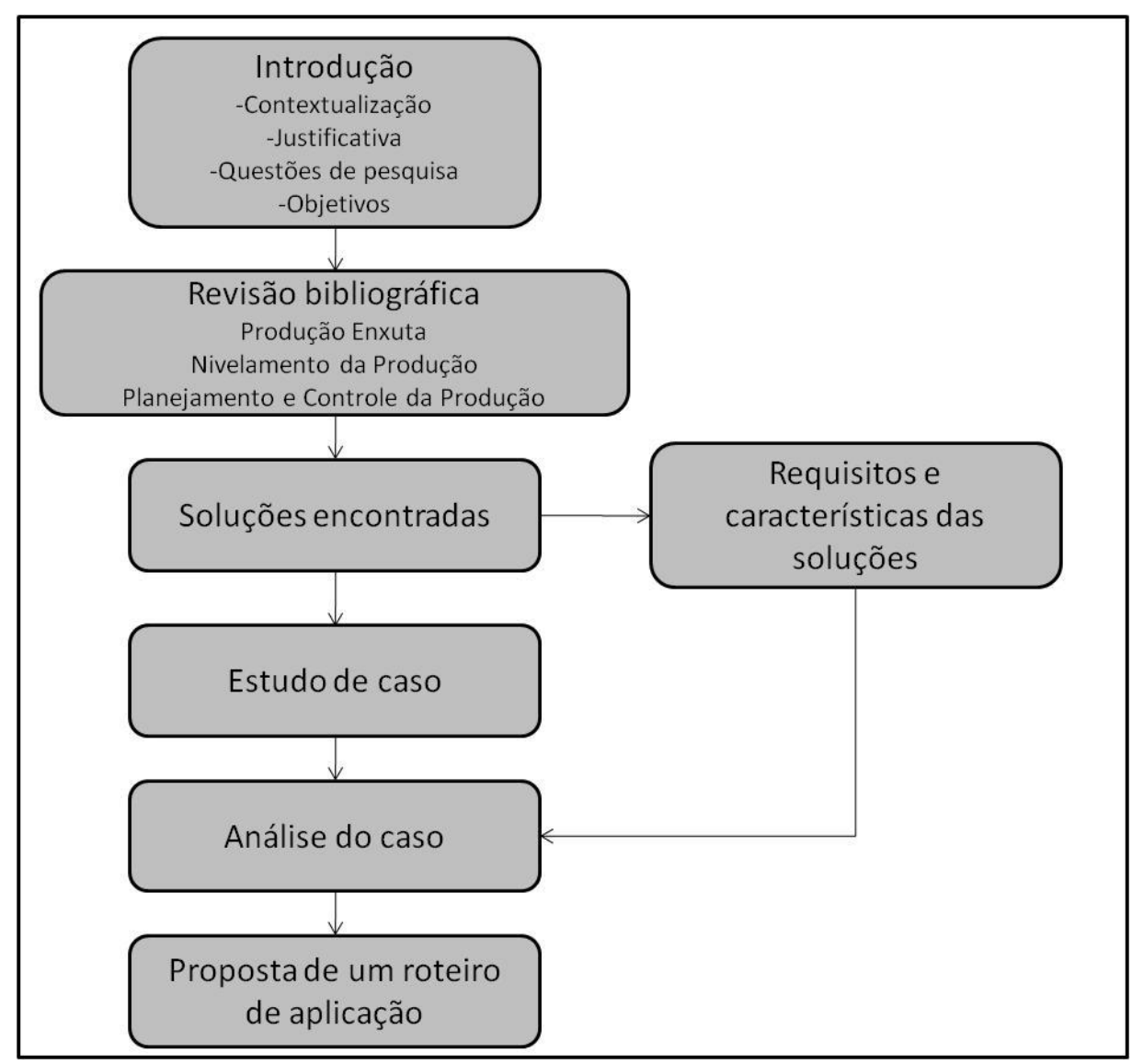

Figura 1 - Esquema sobre as fases de trabalho 


\subsection{Organização do Trabalho}

A estrutura e organização do texto do trabalho aqui apresentado seguem a seguinte ordem:

No Capítulo 1 são apresentados o tema do trabalho através do contexto do trabalho, a apresentação do problema, os objetivos, a metodologia de pesquisa e de desenvolvimento de trabalho e, por último, as fases do trabalho e a forma de organização do texto.

No Capítulo 2 é apresentada a revisão da literatura, onde foram pesquisados alguns assuntos referentes ao tema discutido e que servirão como embasamento teórico para os estudos realizados e desenvolvimento da monografia. Os principais temas considerados neste trabalho são os conceitos de Produção Enxuta, Nivelamento da Produção e Planejamento, Programação e Controle da Produção.

No Capítulo 3 é apresentado o método proposto pela autora para programação e nivelamento do processo puxador.

No Capítulo 4 é discutida a aplicação referente ao modelo proposto onde são mostradas a implantação e os resultados obtidos com a aplicação do método.

No Capítulo 5 é mostrada uma análise da aplicação e as conclusões finais sobre o assunto discutido neste trabalho.

Ao final do trabalho, no Capítulo 6, são citadas as obras utilizadas como referências bibliográficas para a elaboração desta pesquisa. 


\section{CAPÍTULO 2 - REVISÃO DA LITERATURA}

A revisão bibliográfica deste trabalho tem como objetivo apresentar os conceitos encontrados na literatura sobre alguns assuntos relevantes para sua realização.

O primeiro assunto apresentado se refere aos aspectos gerais de Produção Enxuta. Outro assunto relevante é a Planejamento e Controle da Produção, desde seus conceitos mais gerais até focos mais específicos.

A partir destes dois assuntos são apresentados os conceitos sobre Programação e Controle da Produção em ambientes com aplicação dos conceitos de Produção Enxuta. Ainda dentro do assunto Programação e Controle da Produção em ambientes de Produção Enxuta, são tratados os conceitos mais específicos sobre ambientes com alta variedade de produtos e ambientes com tipologia de produção ETO.

\subsection{Conceitos de Produção Enxuta}

Segundo Liker (2004), com o desenvolvimento do Sistema Toyota de Produção (TPS), no Japão pós-guerra por Taiichi Ohno, engenheiro da Toyota, criou-se a filosofia Lean. Essa filosofia começou a ser percebida pelo mundo, pois aplicando os conceitos desse pensamento, a Toyota se destacou pela alta produtividade, confiança dos clientes em seus produtos, velocidade de produção e flexibilidade. O surgimento dessa filosofia, em contradição à produção em massa utilizada, até então, pelos americanos aconteceu, pois:

- O mercado japonês apresentava uma demanda de alta variedade de produtos e baixas quantidades, ou seja, com características diferentes da demanda americana. Dessa forma, não era possível aplicar os conceitos de produção em massa. 
- A redução de custos era conseguida pelos Estados Unidos através dos lotes grandes da Produção em Massa. Porém, no Japão pós-Guerra o crescimento econômico era lento e, portanto, a Produção em Massa não poderia ser aplicada.

A partir dos pontos supracitados a Toyota iniciou a criação do Sistema Toyota de Produção que se transformou no que é conhecido hoje como Produção Enxuta.

A Produção Enxuta surgiu da necessidade da Toyota em competir com as montadoras americanas ao final da guerra. Para isso desenvolveram um método para que fossem identificados e eliminados radicalmente os desperdícios. Essa excelência operacional transformou-se em arma estratégica para o contínuo sucesso de seu negócio segundo Liker (2004).

Essa filosofia consiste principalmente em organizar a produção partindo da exclusão ou minimização das ações que não criam valor aos produtos e, ao mesmo tempo, fazendo com que as ações que criam valor aos produtos sejam feitas de maneira mais eficaz e no momento que o cliente deseja. Segundo Ohno (1988), o trabalho da Toyota em relação ao TPS é:

O que estamos fazendo é observar a linha do tempo desde o momento em que o cliente nos faz um pedido até o ponto em que recebemos o pagamento. E estamos reduzindo essa linha do tempo, removendo as perdas que não agregam valor.

A partir dessa idéia, a Toyota, ao invés de obter a margem de lucro a partir do aumento dos preços, tentou reduzir seus custos para conseguir a margem de lucro desejada sem o aumento dos preços. As indústrias manufatureiras, em sua totalidade, devem buscar a redução de custos como uma forma de aumentar seu lucro e tornarem-se mais competitivas (OHNO, 1988), de acordo com a Figura 2 mostrada a seguir: 


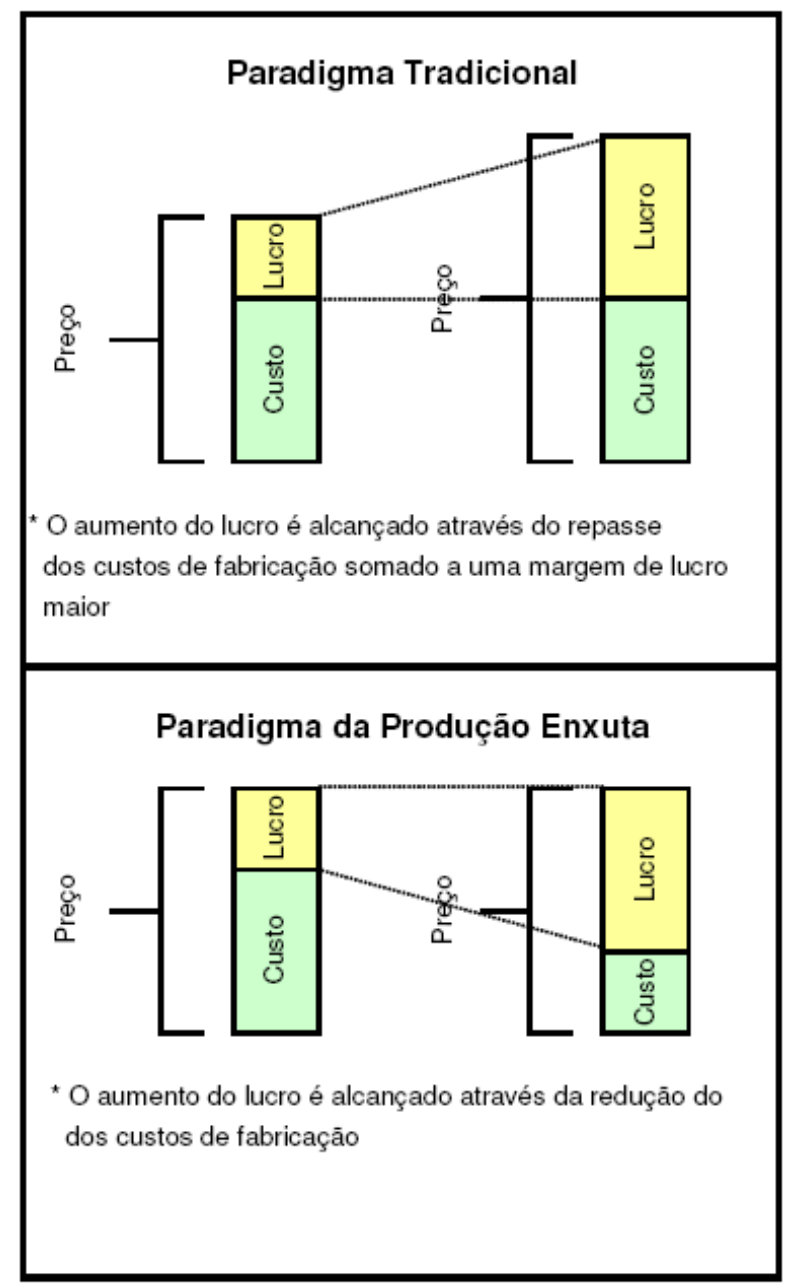

Figura 2 - Aumento dos Lucros na Produção em Massa e na Produção Enxuta

Fonte: Almeida, 2006.

A redução de custos, segundo Ohno (1988), em geral, significa melhorar eficiência dos processos na indústria moderna e nas empresas em geral. Ohno (1988) diz que "a verdadeira melhoria na eficiência surge quando produzimos zero desperdício”, ou seja, todo o tempo de trabalho em uma produção é convertido em tempo de agregação de valor ao produto e não é gasto com atividades que não agregam valor, ou seja, desperdícios de produção.

O termo Produção Enxuta (ou Lean Manufacturing, em inglês, ou ainda, somente Lean) é equivalente ao termo Sistema Toyota de Produção. Para fins didáticos neste trabalho será utilizado, dentre os termos citados, o termo Produção Enxuta. 


\subsubsection{Fundamentos da Produção Enxuta}

O principal foco da Produção Enxuta é, conforme citado anteriormente, a exclusão ou minimização das ações que não criam valor aos produtos, também chamadas de desperdícios, ou seja, o foco é identificar e eliminar de forma sistemática e sustentável todos os desperdícios da cadeia produtiva. Segundo Womack e Jones (1998), “desperdício é qualquer atividade que absorve recursos, mas não cria valor”.

Todas as atividades que acontecem em um sistema produtivo podem ser classificadas da seguinte maneira:

- Atividades que agregam valor (AV): atividades que, aos olhos do cliente final, tornam o produto ou serviço mais valioso.

- Atividades necessárias mas que não agregam valor: atividades que, aos olhos do cliente final, não tornam o produto ou serviço mais valioso, mas que são necessárias a não ser que o processo atual mude radicalmente. Essas atividades são chamadas também de muda tipo 1.

- Atividades que não agregam valor (NAV): atividades que, aos olhos do cliente final, não tornam o produto ou serviço mais valioso e não são necessárias mesmo nas atuais circunstâncias. Essas atividades são chamadas também de muda tipo 2.

A Figura 3 mostra a participação de cada um dos tipos de atividades em uma empresa tradicional, onde cerca de 5\% do tempo gasto é utilizado com atividades que agregam valor, enquanto que cerca de $95 \%$ do tempo gasto é utilizado com atividades que não agregam valor necessárias ou não. Além disso, a Figura 3 mostra, esquematicamente, os enfoques da produção enxuta e da produção em massa que são, respectivamente, a redução do tempo utilizado com as atividades que não agregam valor (ou seja, desperdícios) e a redução do tempo utilizado com as atividades que agregam valor. 


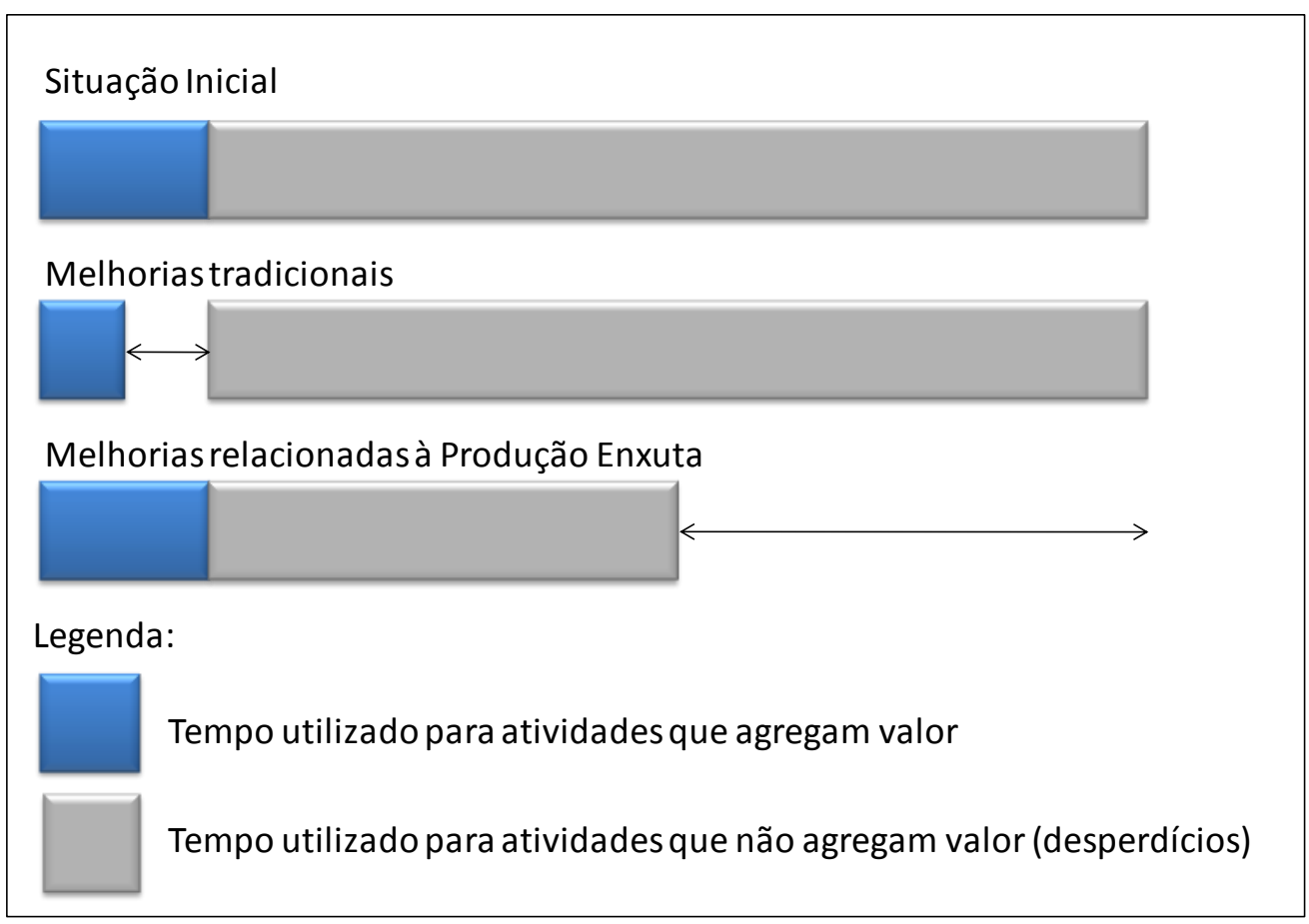

Figura 3 - Composição das atividades e os enfoques da Produção Enxuta e Produção em Massa

Fonte: Adaptado de HINES e TAYLOR (2000)

A partir dessas figuras, é possível verificar que as empresas tradicionais são ambientes bastante propícios para as melhorias voltadas à redução das atividades que não agregam valor ao produto, que são também chamadas de desperdícios de produção.

\subsubsection{Os Sete Desperdícios}

Desperdícios de produção, segundo Womack e Jones (1996), são atividades que absorvem recursos, mas não criam valor e podem ser classificados em alguma das sete categorias de desperdício da Produção Enxuta (SHINGO, 1996):

Superprodução: Significa produzir em grande quantidade ou muito cedo resultando em excesso de inventário. Essas perdas podem ocorrer quando:

- a produção é feita além da quantidade programada (também chamada de superprodução quantitativa); 
- antes do momento programado (também chamada de superprodução antecipada);

Nesses casos, segundo Corrêa e Gianesi (2001), a produção feita acima da quantidade necessária ocorre geralmente por problemas e restrições do processo produtivo, que fazem com que não seja possível produzir em menores quantidades. Esses problemas e restrições são os altos tempos de setup, incerteza na ocorrência de problemas de qualidade e confiabilidade dos equipamentos, falta de coordenação entre a demanda e a produção, layout físico inadequado fazendo com que o material percorra grandes distâncias e levando à formação de lotes para movimentação.

Defeitos: São erros freqüentes no processamento de informação, problemas na qualidade do produto ou baixo desempenho na entrega. Esse tipo de perda ocorre quando:

- os produtos não atendem às especificações;

Segundo Corrêa e Gianesi (2001), a produção, quando produz produtos defeituosos está desperdiçando materiais, disponibilidade de equipamentos e mão-de-obra e movimentação e armazenamento de materiais defeituosos.

Esperas: Longos períodos de inatividades de bens, pessoas e informações. Essas perdas podem ocorrer quando:

- o lote posterior espera o término do lote em processo

- um produto aguarda o processamento dos outros produtos do seu lote

- o operador permanece junto à máquina para acompanhar o processamento do início ao fim

Processamento Inapropriado: Executar o processo utilizando ferramentas ou procedimentos não apropriados;

Segundo Corrêa e Gianesi (2001), qualquer elemento que adicione custo e não adicione valor ao produto é candidato à investigação para checar se é possível reduzir o número de componentes ou operações necessárias para produzir um produto.

Inventários Desnecessários: Armazenamento excessivo de matéria-prima, estoque em processo ou produtos acabados; 
Os estoques estão presentes na produção e são conseqüência de alguns acontecimentos (citados no desperdício de Superprodução).

A Figura 4 mostra uma analogia ao problema que ocorre com altos níveis de estoques. A água representa o nível de estoque; ao baixar o nível da água, são encontradas pedras que representam os problemas de produção, que são divididos em, basicamente, três tipos: problemas de qualidade, problemas de quebras de máquinas e problemas de preparação de máquina.

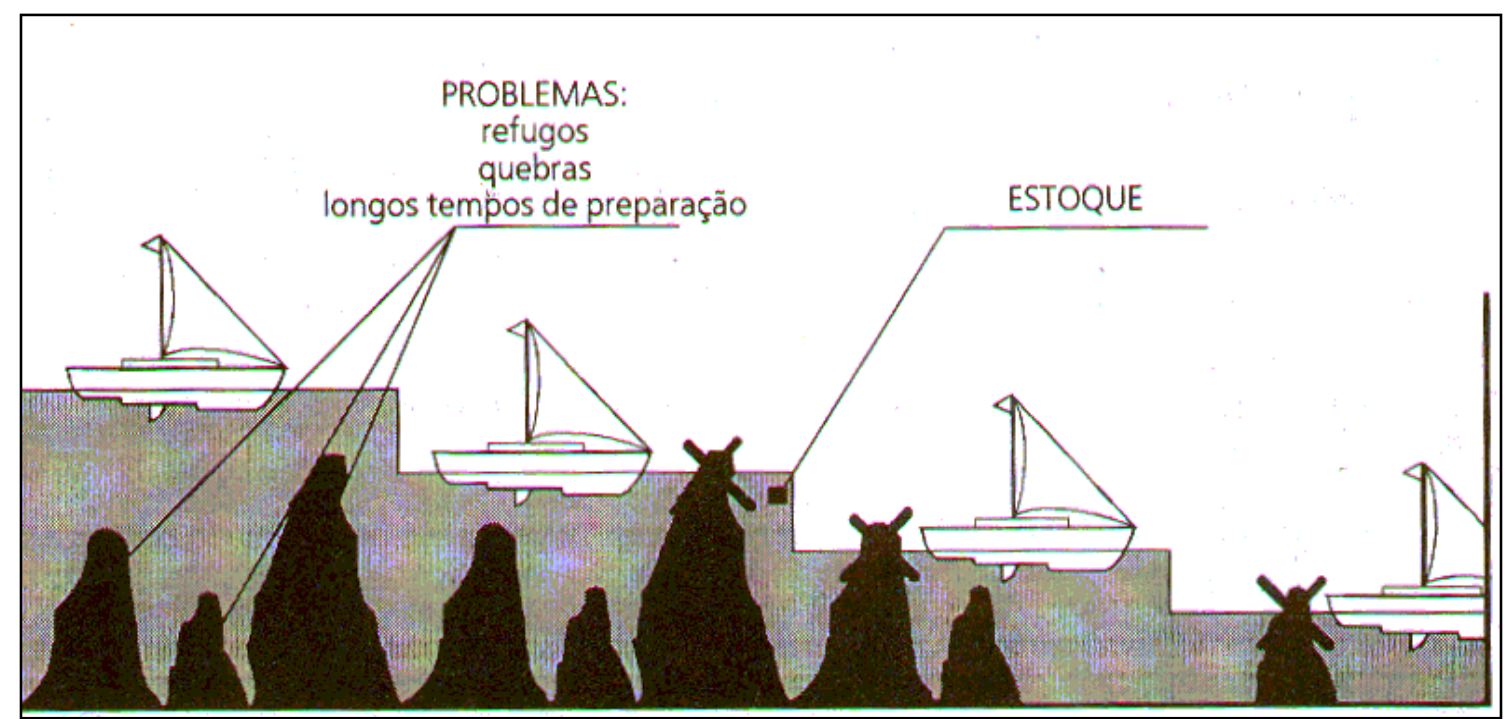

Figura 4 - Redução dos estoques e a exposição dos problemas da produção

Fonte: Corrêa e Gianesi (1993)

Movimentação Excessiva: Excesso de movimentação dos operadores movendo ou armazenando peças;

A redução de movimentação é importante pois reduz o tempo associado ao processo produtivo e aumenta a produtividade, pois o tempo antes utilizado para movimentação de operadores fica disponível para realização de atividades que agreguem valor ao produto (CORRÊA e GIANESI, 2001).

Transporte Excessivo: Transporte excessivo de bens e informações. Esse tipo de perda pode ocorrer quando: 
- Transporte desnecessário de matérias-primas, estoque em processo e produtos acabados;

O excesso de transporte ocorre pela necessidade de armazenamento de um volume alto de peças em estoque e pelas grandes distâncias entre equipamentos em arranjos físicos inadequados. Portanto, para reduzir esse desperdício, é importante que ocorra a redução do nível de estoques e seja elaborado um arranjo físico adequado (CORRÊA e GIANESI, 2001).

Algumas causas e suas possíveis soluções atreladas a cada desperdício apresentado são mostradas, segundo Nazareno (2003), na Tabela 2: 
Tabela 2 - Causas e Soluções para os Tipos de Desperdícios

Fonte: Adaptado de Nazareno (2003)

\begin{tabular}{|c|c|c|}
\hline Desperdícios & Possíveis Causas & Possíveis Soluções \\
\hline \multirow{3}{*}{ 1. Superprodução } & Áreas grandes de depósitos & Reduzir o setup \\
\hline & Custos elevados de transporte & Fazer só o necessário \\
\hline & Falhas no PCP & "Puxar" a produção \\
\hline \multirow{3}{*}{ 2. Transporte Excessivo } & Layout inadequado & \begin{tabular}{|l} 
Projetar layout para minimização do \\
transporte
\end{tabular} \\
\hline & Lotes grandes & \multirow{2}{*}{ Reduzir a movimentação de material } \\
\hline & Produção com grande antecedência & \\
\hline \multirow{6}{*}{ 3. Estoque } & \multirow{2}{*}{ Aceitar superprodução } & Sincronizar o fluxo \\
\hline & & Reduzir setups \\
\hline & \multirow[b]{2}{*}{ Produto obsoleto } & Reduzir lead times \\
\hline & & \begin{tabular}{|l|l}
$\begin{array}{l}\text { Realizar a produção acompanhando a } \\
\text { demanda }\end{array}$ \\
\end{tabular} \\
\hline & \multirow[t]{2}{*}{ Grande flutuação da demanda } & $\begin{array}{l}\text { Promover a utilização de projeto modular } \\
\text { dos produtos }\end{array}$ \\
\hline & & Reduzir os demais tipos de desperdícios \\
\hline \multirow{4}{*}{ 4. Esperas } & Espera por materiais & Sincronizar o fluxo de material \\
\hline & Espera por informações & $\begin{array}{l}\text { Balancear a linha com trabalhadores } \\
\text { flexíveis }\end{array}$ \\
\hline & Layout inadequado & \multirow{2}{*}{ Realizar manutenção preventiva } \\
\hline & Imprevistos de produção & \\
\hline \multirow{3}{*}{ 5. Defeitos } & Processos de fabricação inadequados & $\begin{array}{l}\text { Utilizar mecanismos de prevenção de } \\
\text { falhas }\end{array}$ \\
\hline & Falta de treinamento & \multirow{2}{*}{ Não aceitar defeitos } \\
\hline & Matéria-prima defeituosa & \\
\hline \multirow{4}{*}{$\begin{array}{l}\text { 6. Processamento } \\
\text { Inadequado }\end{array}$} & Ferramentas e dispositivos inadequados & \multirow{2}{*}{ Analisar e padronizar processos } \\
\hline & Falta de padronização & \\
\hline & Material inadequado & \multirow{2}{*}{$\begin{array}{l}\text { Garantir a qualidade do material } \\
\text { ferramentas e dispositivos }\end{array}$} \\
\hline & Erros ao longo do processo & \\
\hline \multirow{4}{*}{$\begin{array}{l}\text { 7. Movimentação } \\
\text { Excessiva }\end{array}$} & Layout inadequado & Realizar estudo de movimentos \\
\hline & Padrões inadequados de ergonomia & Reduzir deslocamentos \\
\hline & $\begin{array}{l}\text { Disposição e/ou controle inadequado de } \\
\text { peças, matéria-prima, material de } \\
\text { consumo, ferramentas e dispositivos }\end{array}$ & \multirow[t]{2}{*}{ Adotar sistemas de controle pertinentes } \\
\hline & Itens perdidos & \\
\hline
\end{tabular}

Outra classe de desperdício pouco discutida, porém de grande importância, é o desperdício da criatividade dos operadores que atuam diretamente nos processos produtivo. Esses operadores normalmente, não são envolvidos ou ouvidos em processos de melhoria (LIKER, 2004). 


\subsubsection{Princípios da produção enxuta}

Além dos desperdícios apresentados há, na mentalidade enxuta, cinco princípios que explicam como devem ser aplicados os conceitos dessa filosofia (WOMACK,1996):

Valor

O primeiro princípio consiste em definir o que é valor do ponto de vista do cliente. É identificar a necessidade do cliente e pelo que ele está disposto a pagar.

\section{Fluxo de Valor}

Identificar o fluxo de valor significa enxergar todo o fluxo do produto e não as atividades isoladas pelas quais ele passa. Essas atividades podem ser classificadas em: atividades que agregam valor, atividades que não agregam valor mas que são necessárias e atividades que não agregam valor.

\section{Fluxo Contínuo}

Determinar onde é possível criar fluxo contínuo. O fluxo contínuo consiste em produzir somente um item de cada vez, passando ao próximo processo sem que haja acúmulo de peças formando estoque intermediário entre os processos.

O fluxo contínuo permite que a empresa reduza bastante o tempo de concepção do produto, possibilitando uma resposta rápida da empresa aos pedidos dos clientes.

\section{Produção Puxada}

A alternativa, quando não é possível criar fluxo contínuo entre os processos, é conectar os processos através da produção puxada.

A produção puxada faz com que os processos façam somente a necessidade do processo cliente, isto é, somente a quantidade necessária no momento correto. Esse assunto será detalhado adiante.

\section{Perfeição}

Atingir a perfeição deve ser a meta constante dentro de uma empresa. Ao passar pelos princípios citados acima, a empresa consegue enxergar que as oportunidades de 
eliminação de desperdícios podem ser infinitas. Dessa forma a empresa conseguirá, cada vez mais, atingir as expectativas dos clientes.

\subsubsection{Recomendações para a Situação Futura}

A produção enxuta tem por objetivo construir um processo para fazer somente o que o próximo processo necessita e quando necessita através de um fluxo regular que gere o menor lead time, a maior qualidade e o custo mais baixo (ROTHER e SHOOK, 1999). Para chegar a este ponto, é preciso delinear a situação futura, que deve seguir algumas recomendações, mostrados a seguir, que a Toyota utiliza (ROTHER e SHOOK, 1999):

Recomendação 1: Produzir de acordo com o takt time

O takt time pode ser entendido como o ritmo de produção no qual a empresa deve trabalhar para atender a demanda de seus clientes. Ele é calculado através da razão entre o tempo disponível para produção e o número de unidades a serem produzidas.

Recomendação 2: Desenvolver fluxo contínuo onde for possível

Segundo Rother e Shook (1999) produzir em fluxo contínuo significa produzir uma peça a cada, com cada uma delas passando imediatamente de um estágio ao próximo sem nenhuma parada entre eles. A maneira mais eficiente de produção é o fluxo contínuo pois não há, praticamente, nenhum desperdício atrelado a este tipo de produção.

Recomendação 3: Utilizar supermercados para controlar a produção onde o fluxo contínuo não se estende

Há algumas situações em que não é possível implantar fluxo continuo e, para estes casos, é importante conectá-los através de sistemas puxados. Normalmente, os processos em que não é possível trabalhar em fluxo são aqueles que por algum motivo não podem estar perto dos processos seguintes (por exemplo, em fornecedores), processos que devem trabalhar em lotes (por exemplo, fornos e autoclaves) e processos com tempos de ciclo muito rápidos ou muito lentos. 
O sistema puxado, como também é chamado um supermercado, possui o objetivo de, segundo Rother e Shook (1999), "dar a ordem exata de produção ao processo anterior, sem tentar prever a demanda posterior e programar este processo".

Recomendação 4: Tentar enviar a programação do cliente para somente um processo de produção

Com o uso do sistema puxado, é necessário programar apenas um ponto do fluxo de valor. Esse ponto do fluxo de valor é chamado de processo puxador. O processo puxador é frequentemente o último processo em fluxo contínuo no fluxo de valor porta-a-porta. A Figura 5 mostra dois exemplos de fluxo de valor com o processo puxador definido.

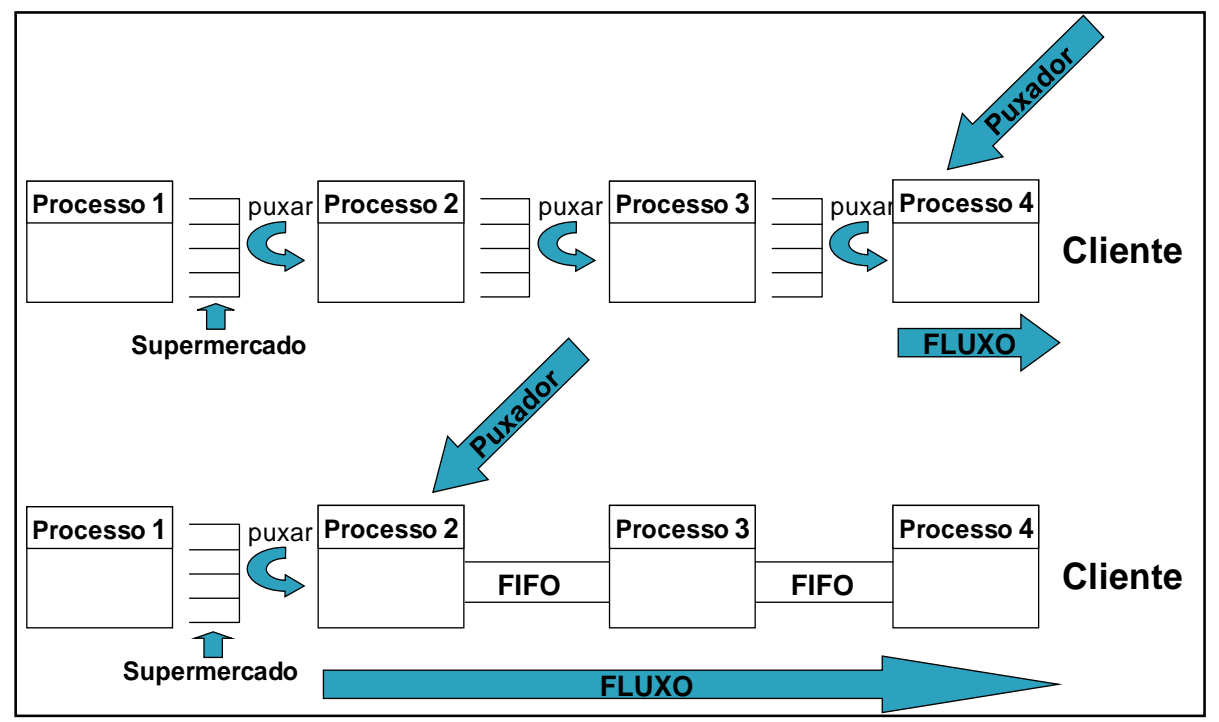

Figura 5 - Exemplos de definição do processo puxador

Fonte: Adaptado de Rother e Shook (1999)

Recomendação 5: Distribuir a produção de diferentes produtos uniformemente no decorrer do tempo no processo puxador (Nivelar o mix de produção)

Produzir em lotes com grandes quantidades de peças implica na dificuldade de atendimento das necessidades dos clientes que irão querer peças diferentes da que está sendo produzida. Para atender a essa demanda, ao trabalhar com lotes de grandes quantidades, é necessário ter um estoque de produto acabado maior e, por conseqüência, um lead time mais longo para atender aos pedidos (ROTHER e SHOOK, 1999). 
Segundo Rother e Shook (1999), nivelar o mix de produtos significa distribuir a produção de diferentes produtos uniformemente durante um período de tempo. De acordo com a Figura 6, ao invés de uma produção desnivelada onde é produzido um lote com muitas unidades de um produto e, depois disso, um lote com muitas unidades de outro produto devese intercalar a produção entre os dois produtos, de forma nivelada, com lotes em pequenas quantidades de cada um deles.

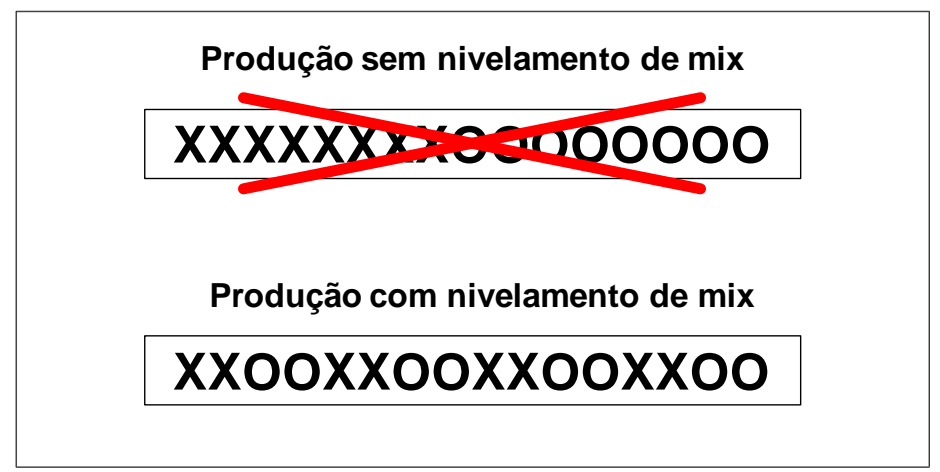

Figura 6 - Nivelamento do mix de produção no processo puxador

Fonte: Adaptado de Rother e Shook (1999)

Recomendação 6: Criar uma "puxada inicial" com a liberação e retirada de somente um pequeno e uniforme incremento de trabalho no processo puxador (Nivelar o volume de produção)

Assim como o nivelamento do mix de produção, o nivelamento do volume de produção aumenta a chance de conseguir responder às diferentes solicitações dos clientes.

Para nivelar o mix e o volume de produção é normalmente utilizado o heijunka box. O heijunka box é um quadro onde é mostrada a programação do processo puxador. Para cada incremento pitch está programado para ser produzido um determinado produto. Um incremento pitch é dado, normalmente, pela multiplicação do takt time do produto e pela quantidade de produtos em uma embalagem.

Recomendação 7: Desenvolver a habilidade de fazer "toda peça todo dia" nos processos de fabricação anteriores ao processo puxador

Lotes em quantidades menores e tempos de setup reduzidos permitem melhor resposta às necessidades dos clientes. Essa flexibilidade da produção pode ser expressa 
através do TPT que significa "toda parte todo ...". O TPT descreve a freqüência com que um processo se modifica para produzir todas as peças. Para as principais peças é interessante que a empresa atinja "toda peça todo dia" (ou seja, TPT de 1 dia) para garantir a flexibilidade necessária.

A Figura 7 mostra uma produção de 6 tipos diferentes de peças (de A a F) para exemplificar o conceito de TPT, que na figura, pode ser entendido como o tempo transcorrido entre a produção da peça A até a próxima vez que a peça A é produzida.

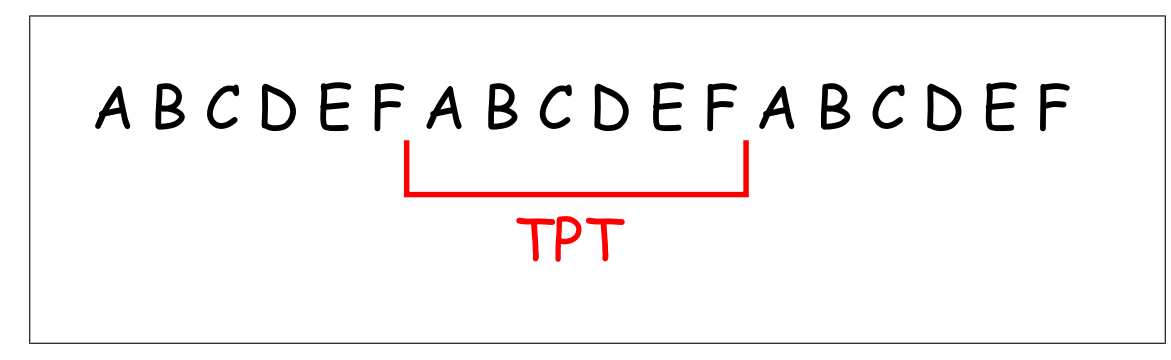

Figura 7 - Significado de "toda parte toda..." ou TPT

Fonte: Adaptado de Rother e Shook (1999)

\subsubsection{Fluxo de Valor}

De acordo com Rother e Shook (1999), "um fluxo de valor é toda ação (agregando valor ou não) necessária para trazer um produto por todos os fluxos essenciais a cada produto, como o fluxo de produção, desde a matéria prima até os braços do consumidor, ou o fluxo do projeto do produto, da concepção até o lançamento".

Além do fluxo de material há o fluxo de informação também, que deve ser tratado com a mesma importância dada ao fluxo de informação (ROTHER e SHOOK, 1999).

Para enxergar todo o fluxo de valor é utilizada a ferramenta de Mapeamento do Fluxo de Valor com o objetivo de documentar tanto o fluxo de valor dos materiais quanto o de informação e conseguir enxergar além de processos distintos, enxergar o fluxo de valor e as fontes de desperdícios do fluxo. 


\subsubsection{Mapeamento do Fluxo de Valor}

O Mapa de Fluxo de Valor (MFV) é um método utilizado para analisar e diagnosticar a situação atual além de auxiliar no planejamento da situação futura de uma empresa. Segundo Rentes (2000), o fluxo de valor, foco do mapeamento, é "o conjunto de todas as atividades que ocorrem desde a obtenção da matéria-prima até a entrega ao consumidor do produto final".

O método consiste em, após seguir o caminho percorrido pelo material, desde o fornecedor até o cliente, representar visualmente cada processo no fluxo de material e de informação. A partir dessa representação visual é possível identificar os grandes focos de desperdícios (ROTHER; SHOOK, 1999).

A forma de utilização da ferramenta é apresentada na Figura 8, onde são apresentadas as etapas para mapeamento do fluxo de valor. Para mapear o fluxo de valor deve-se iniciar selecionando uma família de produtos. Uma família de produtos compreende produtos que passam por processos semelhantes realizados nas mesmas máquinas.

O próximo passo é desenhar o mapa de fluxo de valor da situação atual. A partir do atual deve-se desenhar o mapa de fluxo de valor da situação futura. Por último, é necessário que seja preparado um plano de ação. Neste plano de ação deverão conter as ações, escritas de forma bastante objetiva, de como se pretende chegar à situação futura (ROTHER; SHOOK, 1999). 


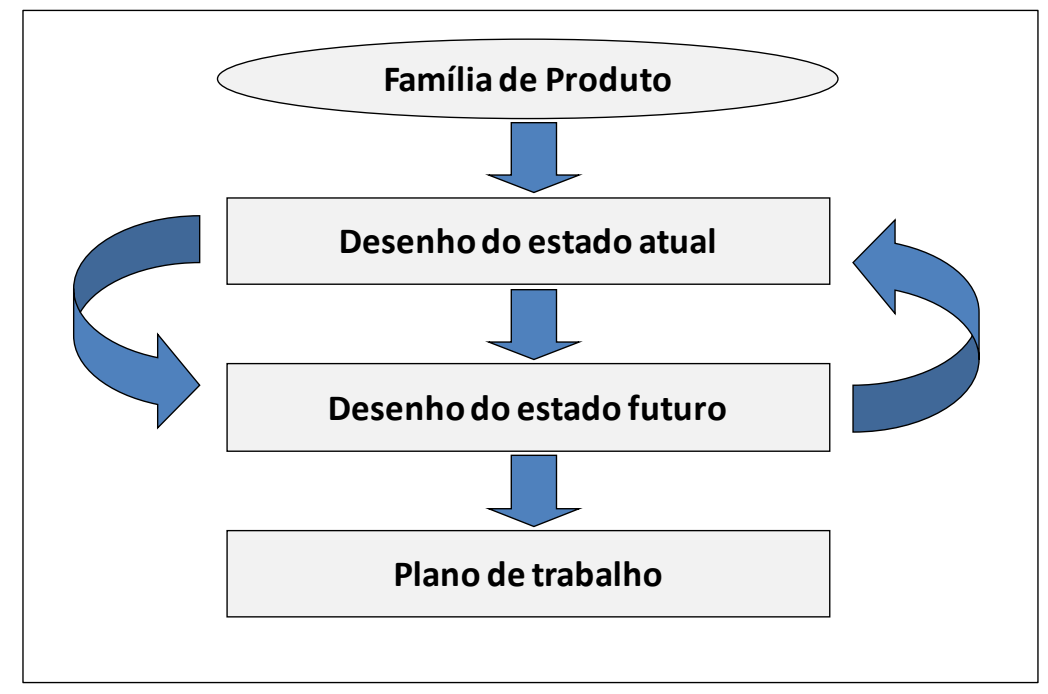

Figura 8 - Etapas de mapeamento do fluxo de valor

Fonte: Adaptado de Rother e Shook (1999)

Para desenhar o mapa de fluxo de valor são utilizados ícones que representam os processos e os fluxos que são mostrados na Figura 9. Dependendo da necessidade, pode-se criar novos ícones para realizar o mapeamento (ROTHER e SHOOK, 1999).

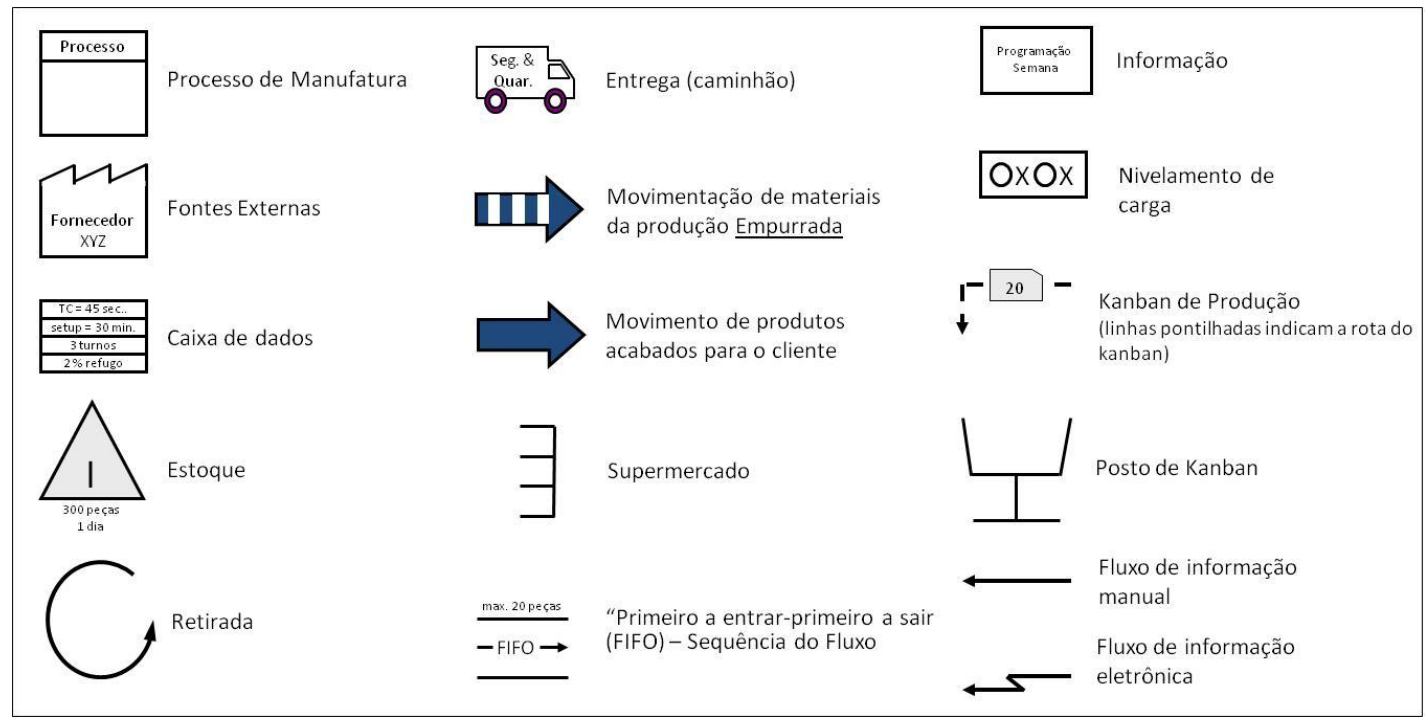

Figura 9 - Ícones para Mapeamento do Fluxo de Valor

Fonte: Adaptado de Rother e Shook (1999)

Além dos ícones apresentados anteriormente, a Hominiss Consulting criou um ícone que é uma extensão do ícone de processo que com o objetivo de identificar, em um MFV, um processo que é compartilhado entre duas ou mais famílias de produtos (RENTES, 2009). Esse 
ícone é mostrado na Figura 10 e é caracterizado pela caixa de processo com um pequeno traço na diagonal no canto inferior direito da caixa de processo.

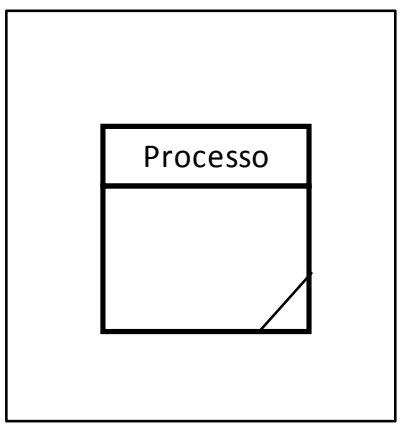

Figura 10 - Ícone para representação de processos compartilhados em um MFV

Fonte: Rentes (2009)

A Figura 11 mostra um exemplo de mapeamento de fluxo de valor de um sistema produtivo.

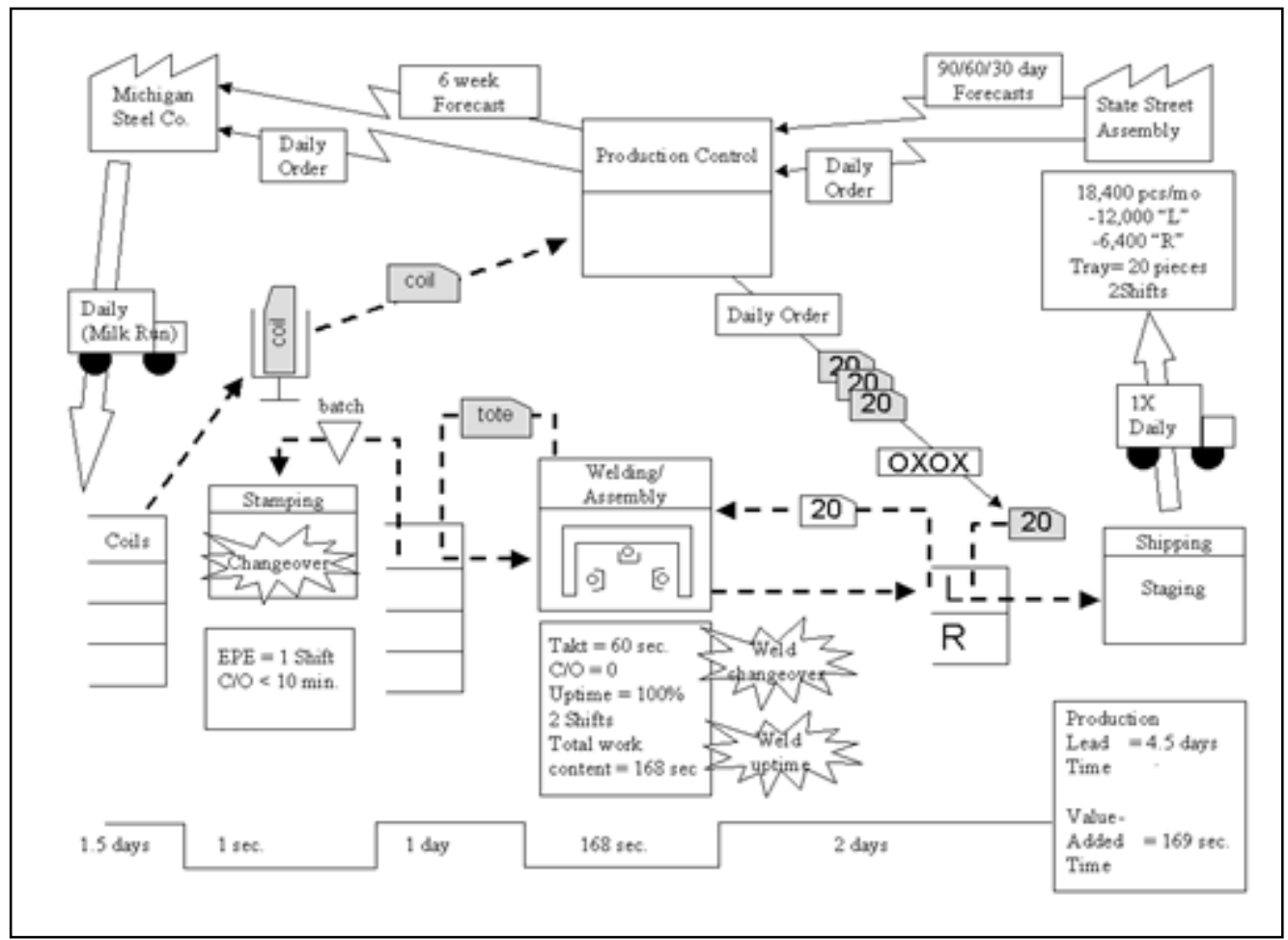

Figura 11 - Exemplo de um mapa de fluxo de valor

Fonte: Rother e Shook (1999) 
Em empresas com alta variedade de produtos, após mapear o fluxo de valor para cada uma das famílias de produtos, nos deparamos com diversos mapas (um para cada família). Nestes casos, o mapeamento do fluxo de valor perde uma das suas principais vantagens: a visibilidade e simplificação dos processos como um todo. Outro ponto negativo é o fato de o MFV não considerar pontos como o layout industrial e a proposição de alternativas para implantação do estado futuro como cronograma, capacitação e treinamento.

\subsubsection{Eventos kaizen}

Muitas empresas atualmente enxergam os eventos kaizen como uma forma diferente da tradicional de implantar melhorias (MANOS, 2007).

Segundo Perin (2005), o efeito cumulativo das melhorias de pequena escala é freqüentemente maior que uma simples melhoria de grande escala. E é na implantação dessas melhorias de pequena escala que se encontram os eventos kaizen.

Um evento kaizen é um projeto intenso, focado e de curto prazo para melhorar um processo. Um evento normalmente inclui treinamentos, análises da situação atual, projetos da situação futura, modificações de processos, de produtos e de áreas (PERIN, 2005).

Esse tipo de evento ocorre normalmente em um período de três a oito dias com uma equipe formada por pessoas de diversas áreas, inclusive as áreas que não possuem ligação direta ou indireta com o ponto a ser melhorado no evento kaizen. Durante o período do evento kaizen, a equipe se dedica durante todo tempo às atividades relacionadas ao evento, não trabalhando em nenhum momento nas suas atividades rotineiras (PERIN, 2005).

Há três benefícios bastante específicos e claros de um evento kaizen: o primeiro deles é "tempo", pois há um tempo determinado para realizar as melhorias, diferentemente das melhorias tradicionais que são feitas normalmente só quando se tem tempo disponível para isso; o segundo benefício é "equipe de trabalho", pois todas as melhorias realizadas em um evento kaizen são implantadas através de um time; o terceiro benefício é o "resultado", já que ao final do evento kaizen já é possível enxergar os primeiros resultados das melhorias implantadas (MANOS, 2007) 
Outra grande vantagem na utilização da metodologia de evento kaizen citada por Araujo e Rentes (2006) é "que diretores e gerentes têm percebido o grande desperdício de talentos e idéias, que agora encontram espaço para serem colocados em prática”.

\subsection{Planejamento e Controle da Produção}

Segundo Corrêa, Gianesi e Caon (2001), planejar é "entender como a consideração conjunta da situação presente e da visão de futuro influencia as decisões tomadas no presente para que se atinjam determinados objetivos no futuro" e essa função da produção está contida no sistema de administração da produção.

Para atingir aos objetivos determinados, o sistema de planejamento e controle da produção de uma empresa possui como funções, segundo VOLLMAN (1997):

- Previsão da demanda

- Planejamento agregado

- Programação mestra

- Planejamento de capacidade

- Planejamento de materiais

- Emissão de ordens

- Programação e controle da produção

As atividades que um sistema de administração da produção executa são consideradas implicações estratégicas para a empresa, embora recentemente ainda eram consideradas atividades operacionais. Segundo Corrêa e Gianesi (1993), essas atividades afetam diretamente os níveis de desempenho do sistema de produção em relação aos aspectos de desempenho competitivo supracitados.

Dentre as funções apresentadas anteriormente, a função mais relevante para a este trabalho é a função de Programação e Controle da Produção. Por esse motivo, adiante a função citada será detalhada. 


\subsubsection{Programação e Controle da Produção}

A função de programação e controle da produção, segundo Scarpelli (2006), "tem por finalidade satisfazer o plano de materiais e o programa mestre de produção acionando a fábrica na execução de operações de fabricação dos itens e produtos conforme as quantidades e prazos necessários".

A atividade de programação deve determinar quais os prazos para que as atividades sejam cumpridas através de informações relativas à disponibilidade de equipamentos, matérias-primas disponíveis, tempos de processamento (MOURA JR, 1996).

Segundo Martins (1993), os objetivos da programação e seqüenciamento da produção são:

- Aumentar a utilização dos recursos;

- Reduzir o estoque em processo;

- Reduzir os atrasos no término dos processamentos.

A programação da produção pode ser feita considerando duas abordagens distintas de como as tarefas são atribuídas a centros de trabalho, segundo Gaither e Frazier (2002):

- Carga finita: usada quando as capacidades dos centros de trabalho são alocadas dentre uma lista de tarefas. Essa abordagem está ligada ao CRP e, nela, a capacidade de cada centro de trabalho é alocada para as tarefas hora a hora, evitando que haja sobreposição de tarefas nos centros de trabalho;

- Carga infinita: usada quando as tarefas são atribuídas a centros de trabalho desconsiderando as capacidades desses centros. Nessa abordagem é abandonado o CRP e, a menos que a empresa tenha capacidade excessiva, filas de tarefas à espera ocorrem nos centros de trabalho.

Além disso, há algumas regras de seqüenciamento que se baseiam em diferentes formas de priorizar um item para alocar em um recurso. Algumas regras são Gaither e Frazier (2002):

- Primeiro a entrar, primeiro a ser atendido: a tarefa seguinte é aquela que chegou primeiro em relação às tarefas a serem seqüenciadas; 
- Menor tempo de processamento: a tarefa seguinte é aquela com menor tempo de processamento entre as tarefas a serem seqüenciadas;

- Mais urgente data de vencimento: a tarefa seguinte é aquela com data de vencimento mais urgente;

- Menor folga: a tarefa seguinte é aquela com menor folga, ou seja, tempo até a data de vencimento menos tempo total de produção restante;

- Razão crítica: a tarefa seguinte é aquela que apresenta a menor razão crítica, ou seja, o tempo até a data do vencimento dividido pelo tempo total de produção restante;

- Menor custo de preparação: a seqüência de tarefas é definida considerando a que apresenta o menor custo total de preparações de máquinas entre as tarefas.

Já a atividade de controle da produção possui o objetivo de coletar dados referentes a informações importantes da produção como horas trabalhadas, índice de refugos, quantidade de materiais utilizados, horas paradas e suas respectivas causas. Além da função de coleta das informações, o controle de produção deve avisar, caso haja algum desvio, para as funções de Programação Mestre de Produção, Planejamento de Materiais ou Programação da Produção para que alguma ação seja tomada (MOURA JR., 1996).

Diversos tipos de planejamento e controle da produção existem e estes se diferem basicamente pelo foco dado ao PCP, pela variedade de produtos e pelo volume de produção. Slack et al. (1999) diz que os principais tipos de PCP utilizados pelas empresas e surgidos nas últimas décadas são Just in Time (JIT), MRP II e Tambor-Pulmão-Corda (TPC).

A fim de detalhar os tipos de PCP citados anteriormente, adiante serão discutidos MRP II, TPC, sistema kanban e CONWIP. O Sistema kanban e o CONWIP são apresentados como duas formas de produção puxada que é um dos fundamentos do JIT. Para apresentar o conceito de MRP II é necessário iniciar a discussão com a definição de MRP, já que o primeiro surgiu como uma evolução do conceito de MRP.

\subsubsection{MRP II}

A necessidade de gerenciar alguns elementos básicos da produção fez surgir o modelo MRP nos anos 60 (LAURINDO e MESQUITA, 2000). Basicamente, o modelo MRP, 
cuja sigla significa Material Requirements Planning, de acordo com Slack et al. (1999), "permite que as empresas calculem quantos materiais de determinado são necessários e em que momento", ou seja, segundo Corrêa e Gianesi (1993), “calcular, a partir das necessidades (quantidades e datas) de produtos finais e das estruturas de produto, as necessidades de itens de demanda dependente, ou seja, componentes e materiais".

O cálculo de necessidades de materiais é simples, porém somente a partir dos anos 60 começou a se popularizar devido ao surgimento dos primeiros sistemas computacionais. $\mathrm{O}$ cálculo de MRP é realizado a partir de algumas informações, entre elas (CORRÊA e GIANESI, 1993):

- Demanda: caracterizada pelas quantidades e datas das necessidades dos clientes.

- Estrutura de produtos: mostra todos os componentes que formam um produto final, com suas respectivas quantidades e suas relações de pais e filhos. Entende-se por item pai aquele que é formado por componentes que são, por sua vez, chamados de itens filhos.

- Lead time: tempo necessário para ressuprir um item, o tempo necessário para comprar ou fabricar um item.

Primeiramente, é gerado o programa mestre de produção (MPS) que apresenta a necessidade a partir da quantidade de cada produto final que será necessária para atender a demanda durante um período (LAURINDO e MESQUITA, 2000).

O modelo MRP, ao "explodir a demanda", ou seja, a partir do MPS calcula a quantidade dos itens filhos necessária para produzir toda a demanda dos itens pais e define uma necessidade bruta para cada item, seja ele pai ou filho. A partir daí, são comparadas as necessidades dos itens, chamada de necessidade bruta, com a quantidade projetada de estoque para o período chegando, assim, na necessidade líquida, ou seja, aquela que realmente deve ser requisitada, através de planejamento de ordens, ou comprada (CORRÊA e GIANESI, 1993). A Tabela 3 apresenta um modelo de registro do MRP, onde os recebimentos programados correspondem às ordens em andamento na fábrica e ordens e recebimentos devem ser planejados para evitar que o estoque projetado zere ou fique negativo ao longo do 
tempo. Uma ordem deixa de ser planejada e passa para programada no momento em que é liberada para a fábrica (LAURINDO e MESQUITA, 2000).

Tabela 3 - Modelo de registro do MRP

\begin{tabular}{|l|r|r|r|r|r|r|r|r|c|}
\hline \multicolumn{2}{|c|}{ Período } & 1 & 2 & 3 & 4 & 5 & 6 & 7 & 8 \\
\hline Necessidades Brutas & 100 & 80 & 100 & 50 & 80 & 50 & 100 & 40 \\
\hline Recebimentos Programados & & 200 & & & & & & \\
\hline Estoque Projetado & 170 & 70 & 190 & 90 & 40 & 60 & 10 & 60 & 20 \\
\hline Recebimentos Planejados & & & & & 100 & & 150 & \\
\hline Ordens Planejadas & & & 100 & & 150 & & & \\
\hline
\end{tabular}

"Lead time" $=2$ períodos.

\subsubsection{Kanban}

Uma das principais formas de operacionalização do sistema puxado de produção é o sistema kanban que é considerado uma das principais ferramentas do Just in time, surgiu na Toyota nos anos 70 como uma forma de administrar a produção coordenando-a com a demanda do cliente (CORRÊA e GIANESI, 1993).

A produção puxada, implantada através do sistema kanban, é um sistema de informações que controla toda a fábrica, isto é, dá autorizações de produção, de transporte e informa a localização de componentes através de cartões, conforme esquematizado na Figura 12. Somente quando há cartões kanban é que são produzidas ou retiradas peças de um processo ou estoque e, sempre, na quantidade fixada por esses cartões. 


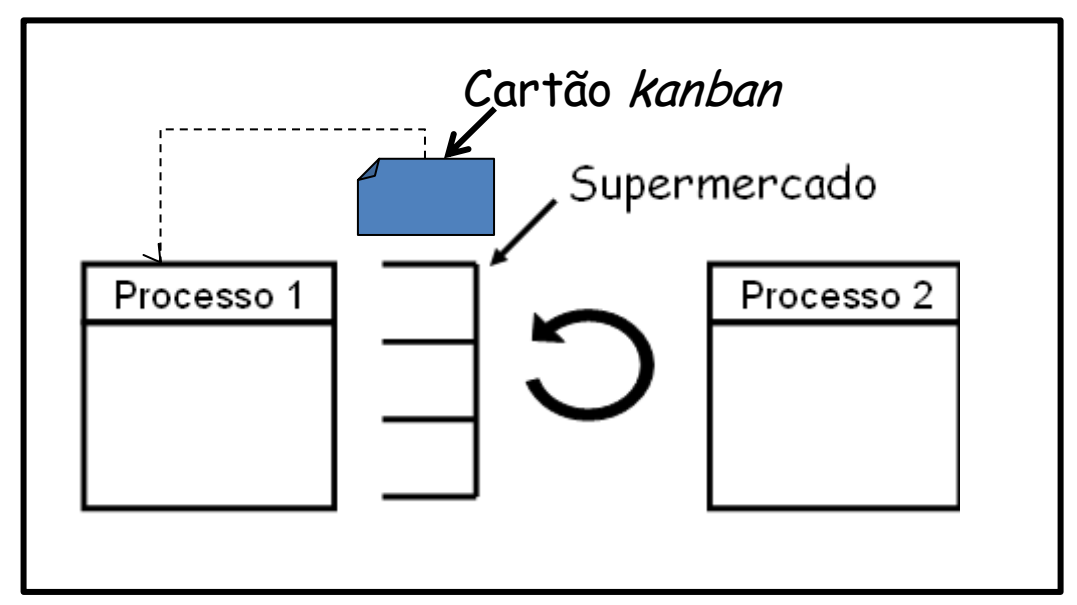

Figura 12 - Funcionamento do sistema kanban

Fonte: Adaptado de Nazareno (2008)

Segundo Slack et al. (1999), embora as abordagens tradicional e o sistema puxado busquem uma alta eficiência da produção, elas fazem isso de maneira distinta. A abordagem tradicional busca a eficiência de cada processo protegendo-o de qualquer parada causada por um processo anterior através de estoques amortecedores, conforme mostrado na Figura 13. Já a abordagem just in time visa expor os problemas do sistema de modo a deixá-los evidentes e gerar ações de maneira a corrigi-los. Dessa forma, no JIT são produzidas peças em um estágio somente quando o próximo estágio necessitar, ou seja, fizer pedidos, conforme mostrado também na Figura 13. 


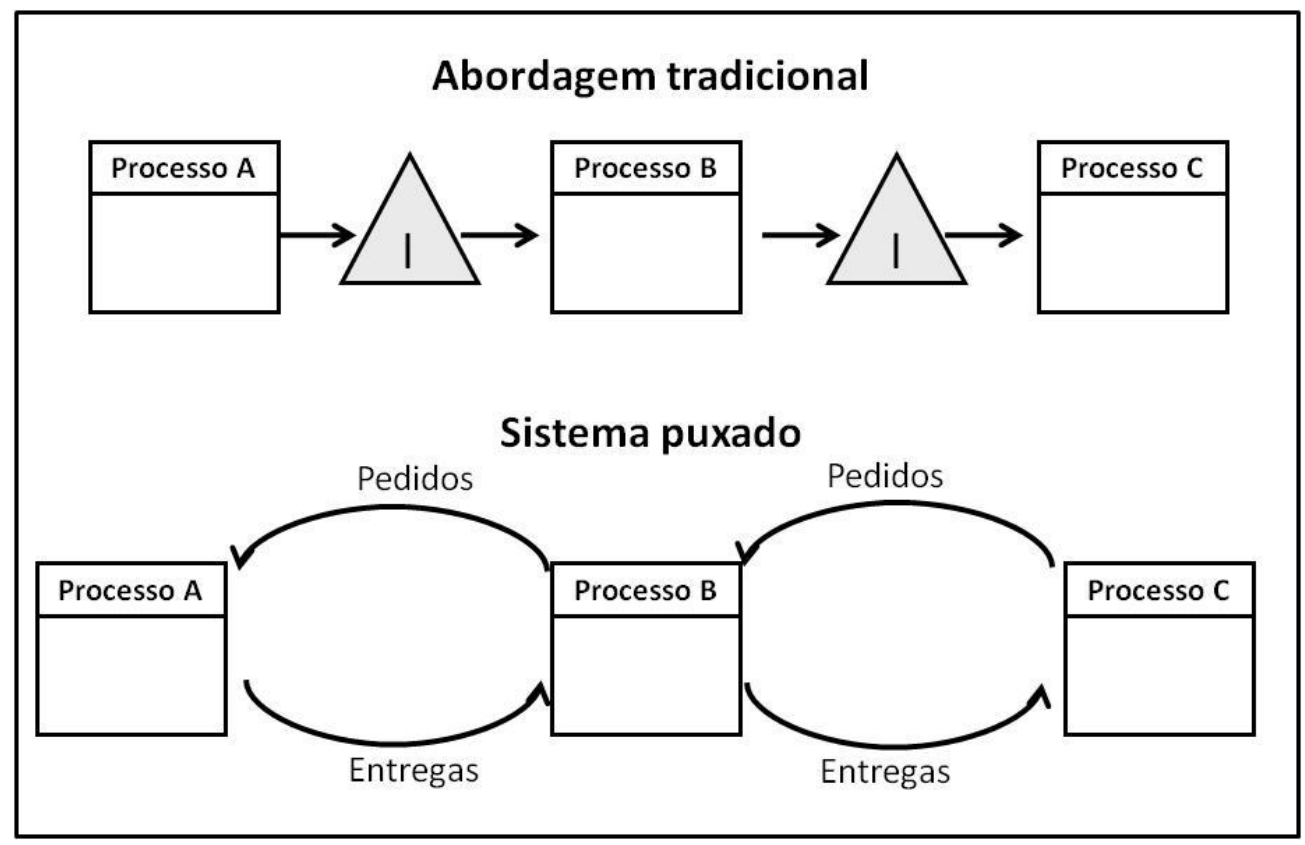

Figura 13 - Diferença entre a abordagem tradicional (sistema empurrado) e o sistema puxado Fonte: Adaptado de Slack et al. (1999)

O termo kanban pode ser traduzido do japonês como cartão ou sinal. O kanban é uma forma de operacionalizar o sistema de planejamento e controle puxado (SLACK et al., 1999). O cartão é a forma de o processo cliente sinalizar para o processo anterior que necessita de mais peças. Ou seja, o recebimento de um ou mais cartões kanban disparam a produção de quantas unidades o(s) cartão(ões) mencionar.

Mais adiante, na Seção 2.2.7.6, serão detalhados mais alguns aspectos referentes ao sistema kanban, como o quadro kanban e o dimensionamento de supermercados.

Segundo Tardin (2001), o nivelamento da produção é um pré-requisito para aplicar a produção puxada, pois caso a produção não esteja nivelada, os estoques de produtos, na forma de supermercados, serão grande demais, reduzindo, assim, os benefícios trazidos pelo sistema. 


\subsubsection{CONWIP}

Uma forma de estabelecer um limite para o WIP é utilizar o método CONWIP, que consiste em permitir que uma nova unidade de produção entre no fluxo, ou sistema, somente quando outra unidade de produção tenha sua produção concluída. Dessa forma, há sempre uma mesma quantidade de unidades de produção no sistema e, por esse motivo, é dado ao método o nome de Constant Work in Process (HOPP e SPEARMAN, 1996).

O CONWIP é um método de produção puxada, pois, segundo Hopp e Spearman (1996), uma diferença fundamental entre um sistema puxado e um sistema empurrado é que "sistemas empurrados controlam a quantidade produzida e observam o WIP, enquanto que sistemas puxados controlam o WIP e observam a quantidade produzida".

A forma de operacionalização do método CONWIP é a utilização de cartões que representam unidades de produção. Um cartão é anexado à(s) peça(s) que representam uma unidade de produção assim que essas entram no fluxo produtivo. Cada vez que alguma unidade de produção termina de ser processada no fluxo, o início do processo recebe o cartão que estava anexado à unidade de produção concluída e, com isso, autoriza que uma nova unidade produção seja iniciada (BOKHORST; SLOMP; GERMS, 2009). conforme Figura 14.

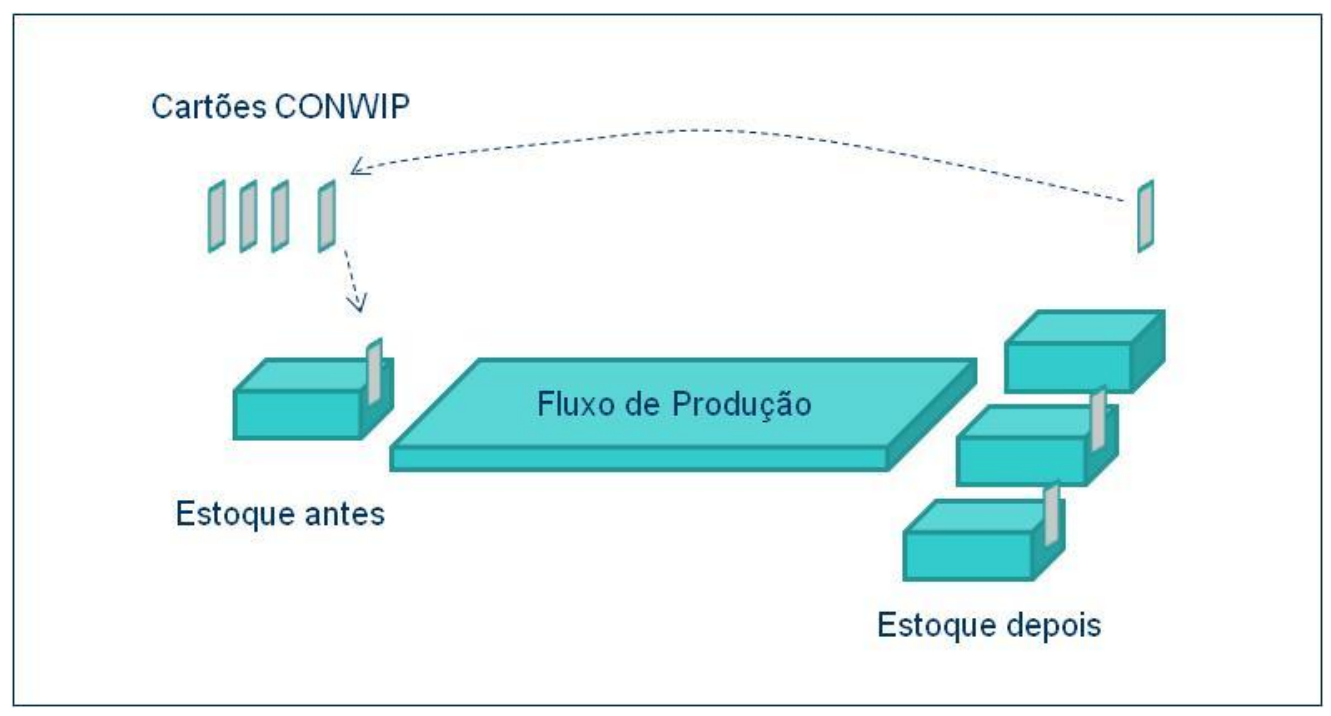

Figura 14 - Utilização de cartões no CONWIP

Fonte: Adaptado de Hopp e Spearman (1996) 


\subsubsection{Tambor - Pulmão - Corda}

A Teoria das Restrições sugere um modelo de programação da produção chamado Tambor - Pulmão - Corda (TPC).

A Teoria das Restrições trata a empresa como um sistema, ou seja, um conjunto de elementos interdependentes cujos esforços conjuntos determinam o desempenho global, e a sua capacidade é limitada por um recurso, denominado recurso restrição (CORBETT, 1997). Segundo Goldratt (1991), entende-se por restrição "qualquer coisa que impeça o sistema de atingir um desempenho maior em relação à sua meta". Para aumentar a capacidade do seu sistema é necessário fazer melhorias apenas no recurso restrição. Ou seja, otimizações locais isoladas (em recursos que não são restrições do sistema) não conduzem à otimização global do sistema.

Assim como é utilizado no método tambor - pulmão - corda, a TOC apresenta um processo decisório em cinco passos:

1. Identificar a restrição do sistema

2. Explorar a restrição do sistema

3. Subordinar tudo o mais à decisão acima

4. Elevar a restrição do sistema

5. Se em algum passo anterior a restrição for quebrada volte ao passo 1

O objetivo da utilização desse processo é poder dar enfoque aos poucos pontos que realmente determinam a capacidade do sistema, ou seja, as restrições do sistema.

De acordo com Umble e Srikanch (2001, apud SOUZA, 2005), o método TPC programa a produção partindo do pressuposto de que existem apenas uns poucos recursos com restrição de capacidade, chamados de RRCs, que impõe o ritmo de produção da fábrica inteira. A esses recursos é dado o nome de "tambor". Para evitar que a produção de um RRC seja comprometida por falta de peça, é criado um estoque antes dele para protegê-lo. A esse estoque é dado o nome de "pulmão". Por fim, para evitar um aumento descontrolado no nível de estoque em processo, o material programado é liberado para a fábrica no mesmo ritmo que o RRC consome o material. A esse procedimento é dado o nome de "corda". 
Importante salientar que, de acordo com Corrêa e Gianesi (1993), há uma diferença entre recurso gargalo e RRC. Em um sistema produtivo pode não haver gargalos reais, ou seja, todos os centros produtivos estão superdimensionados em relação à demanda, porém sempre haverá um recurso que restringirá a produção, que é chamado de RRC. Se, no sistema produtivo, mais de um recurso for gargalo, ou seja, tenha sua capacidade inferior à demanda, será considerado o RRC aquele recurso que estiver mais sobrecarregado.

Seguindo os passos do processo decisório da TOC, o primeiro passo, é identificar uma restrição. Nesse caso, a restrição é o RRC. O segundo passo é explorar a restrição, ou seja, é tomar ações para aproveitar ao máximo esse recurso (SOUZA, 2005) (CORRÊA e GIANESI, 1993) como:

- Evitar que o RRC fique parado durante paradas como trocas de turnos ou refeição;

- Inspecionar rigorosamente para que o RRC não processe peças defeituosas (no qual o defeito foi gerado em processos antecedentes a ele);

- Focalizar esforços de manutenção preventiva e prioridade de manutenção corretiva no RRC;

- Outras ações que evitem que o RRC desperdice tempo de produção.

O terceiro passo é programar a produção iniciando pelo RRC, pois é esse ponto que precisa "bater o tambor", ou seja, ditar o ritmo de produção. Nesse caso, a capacidade do RRC é preenchida por completo para atingir o máximo fluxo possível do sistema produtivo. A partir daí, é definida uma melhor seqüência para as atividades, de acordo com as datas dos pedidos.

O quarto passo é tentar aumentar a capacidade do RRC para aumentar a capacidade do sistema. Esse passo somente deve ser realizado caso todas as ações para explorar o RRC foram tomadas, pois esse aumento pode aumentar as despesas operacionais.

O quinto e último passo é verificar se, durante o primeiro ao quarto passo o RRC passar a ser outro processo. Caso isso aconteça, a seqüência de passos deve ser reiniciada. 


\subsubsection{Programação da Produção em ambientes de Produção Enxuta}

Segundo Salman et al. (2009), a programação da produção em um ambiente com aplicação dos conceitos de produção enxuta "requer suavizar os picos e vales da produção", através do nivelamento da produção. O nivelamento de produção faz parte do conceito de produção enxuta e seu objetivo é fazer com que os níveis de produção sejam distribuídos uniformemente ao longo de um período, evitando que recursos produtivos, como operadores e equipamentos, fiquem ora sobrecarregados e ora ociosos (FURMANS, 2005).

Adiante será descrito como é realizada a programação tradicional de produção enxuta. Além disso, serão discutidas algumas variantes do sistema tradicional, que frequentemente são encontradas em empresas que buscam implantar os conceitos de produção enxuta e sentem dificuldades devido a essas variantes, ou características, do sistema produtivo que elas possuem.

Uma dessas variantes citadas anteriormente é a característica de alta variedade de produtos. Para essa característica, em especial, será discutido como é realizada a programação da produção para esse tipo de ambiente.

\subsubsection{Programação tradicional em ambientes de Produção Enxuta}

Em um ambiente tradicional com aplicação dos conceitos de produção enxuta, a programação da produção ocorre conforme o Mapa de Fluxo de Valor mostrado na Figura 15. Nota-se que no MFV, o cliente envia pedidos (ordens) que são processados pelo PCP e programados em um só ponto da fábrica, chamado de processo puxador. A partir do processo puxador, o processamento deve ocorrer em fluxo contínuo até o cliente. A esquerda do processo puxador há supermercados de itens. Como é um fluxo puxado, a programação dos processos anteriores ao processo puxador, acontece através de cartões. Geralmente, os fluxos puxados se estendem até a matéria-prima. 


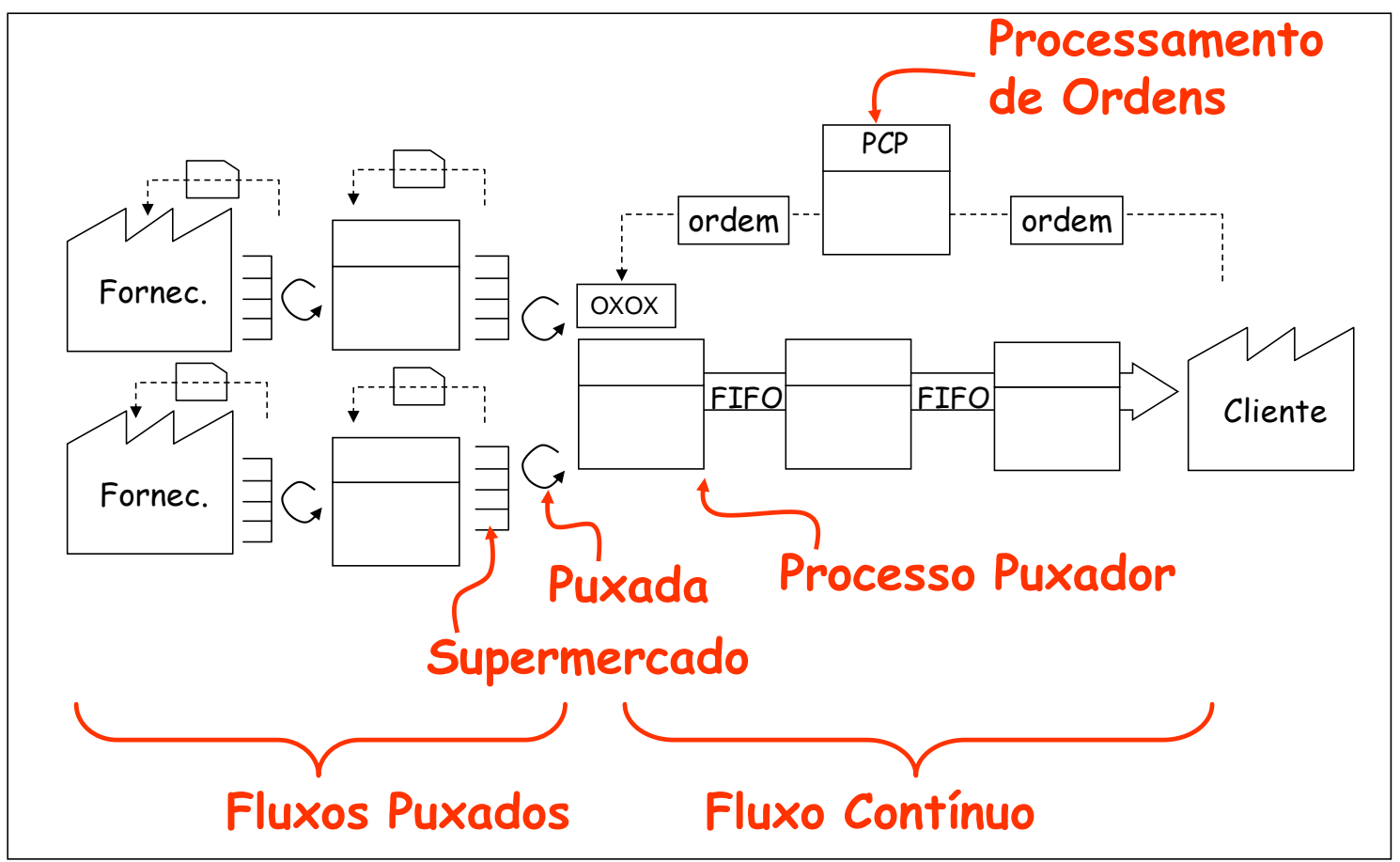

Figura 15 - Visão tradicional de um fluxo enxuto

Fonte: Adaptado de Rentes et al. (2005)

Com o objetivo de detalhar os pontos discutidos na Figura 15, serão apresentados os conceitos básicos para a realização da programação da produção em ambientes de produção enxuta.

\subsubsection{Programação do Processo Puxador}

Em um ambiente enxuto, o fluxo de valor é, geralmente, programado em apenas um ponto, ou seja, apenas um processo recebe a programação da produção vinda do setor de planejamento. A esse processo é dado o nome de processo puxador (SMALLEY, 2004).

Entre o processo puxador e o cliente não deve haver supermercados. Normalmente, o processo puxador é o primeiro processo do último fluxo contínuo do fluxo de valor (ROTHER \& SHOOK, 1999)

A Figura 5 mostra dois exemplos de fluxo onde estão definidos quais são os processos puxadores. No fluxo mostrado na parte de cima da Figura 5 o processo 4 é o processo puxador, já que é o primeiro processo depois do último supermercado do fluxo. Já 
no fluxo mostrado na parte de baixo da Figura 5, o processo 2 é o processo puxador, já que ele é o primeiro processo depois do último supermercado do fluxo.

\subsubsection{Nivelamento de produção}

Produzir de maneira nivelada significa produzir uma variedade de produtos através de um mesmo fluxo de valor de acordo com a necessidade do cliente, ou seja, produzir e entregar a quantidade correta do produto escolhido pelo cliente no momento que o cliente deseja (DUGGAN, 2002).

A palavra japonesa heijunka é utilizada para o nivelamento da produção de forma a manterem-se constantes ao longo do tempo o mix e o volume de produtos (SLACK, 2002).

O nivelamento da produção é uma prática que possibilita a minimização do desperdício de superprodução (MENEGON, NAZARENO e RENTES, 2003). Dessa forma, é possível que a empresa diminua o tempo de resposta ao cliente sem a necessidade de ter grandes quantidades de produtos em estoque (TARDIN, 2001).

A demanda do cliente, em geral, é desnivelada e a tarefa de torná-la nivelada é complexa, já que não é possível decidir pelo cliente sobre a quantidade, o produto e o momento que ele deseja, apesar de haverem algumas técnicas que visam suavizar a variação da demanda. Dessa forma, é propício que haja ferramentas de nivelamento para evitar que essa variação da demanda do cliente aconteça também no processo produtivo (DUGGAN, 2002).

Segundo Rother e Shook (1999), “agrupar os mesmos produtos e produzi-los todos de uma vez, dificulta o atendimento dos clientes que querem algo diferente do lote que está sendo produzido". O fato de produzir lotes maiores reduz a troca de ferramentas nos equipamentos. Por outro lado, fazer lotes maiores implica em maiores estoques de produtos a fim de atender a demanda do cliente ou no aumento do lead time de processamento causado principalmente por lotes esperando o processamento de outras peças (ROTHER e SHOOK, 1999).

Em seu trabalho, Park (1993, apud Tardin, 2001) apresenta um exemplo do impacto do nivelamento no nível de estoque da empresa. Suponhamos uma demanda mensal de 10000 
peças para cada um de quatro produtos distintos (A, B, C, D). O Gráfico 1 mostra o nível de estoque considerando que todas as peças sejam feitas em ciclos mensais, ou seja, cada peça é produzida uma vez ao mês. Já o Gráfico 2 mostra o nível de estoque considerando que todas as peças possam ser produzidas em ciclos de 2 horas, onde as trocas de ferramentas aumentariam e os níveis de material em processo e produtos em estoque seriam reduzidos.

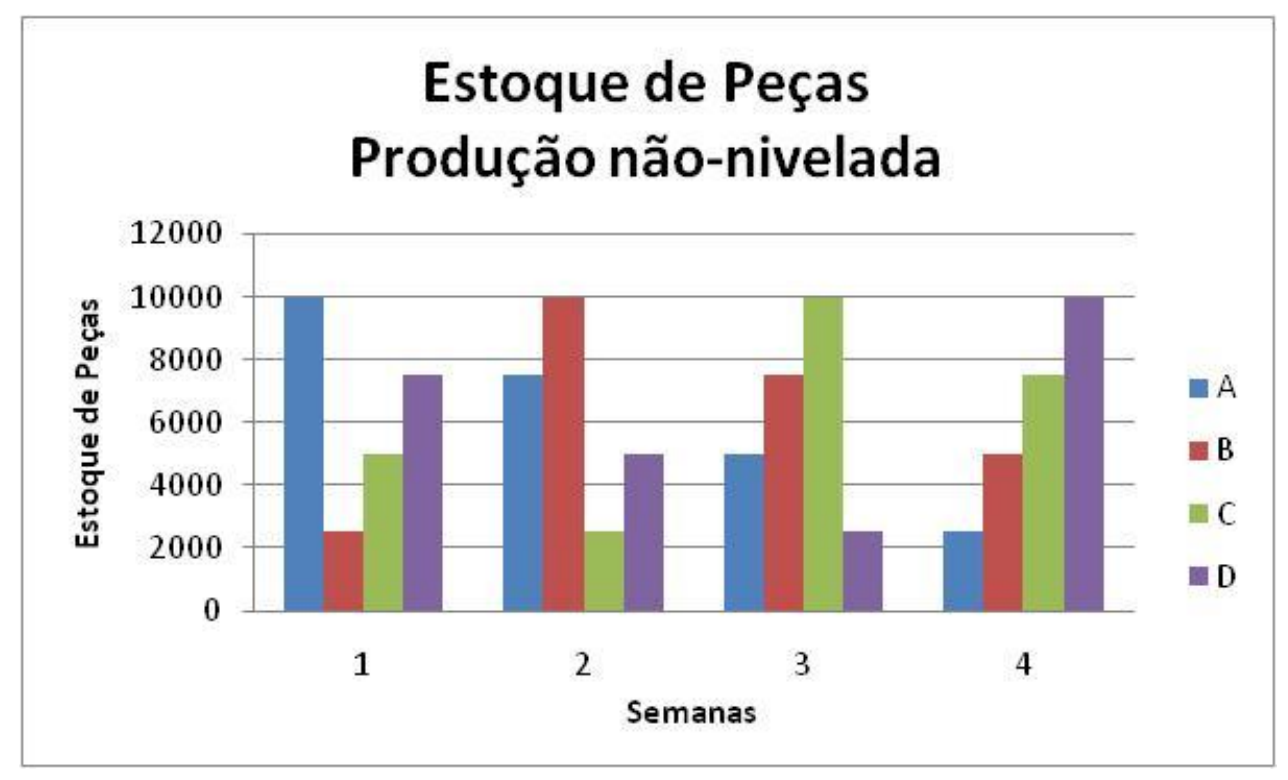

Gráfico 1 - Nível de estoque em uma produção não-nivelada

Fonte: Adaptado de Tardin (2001) 


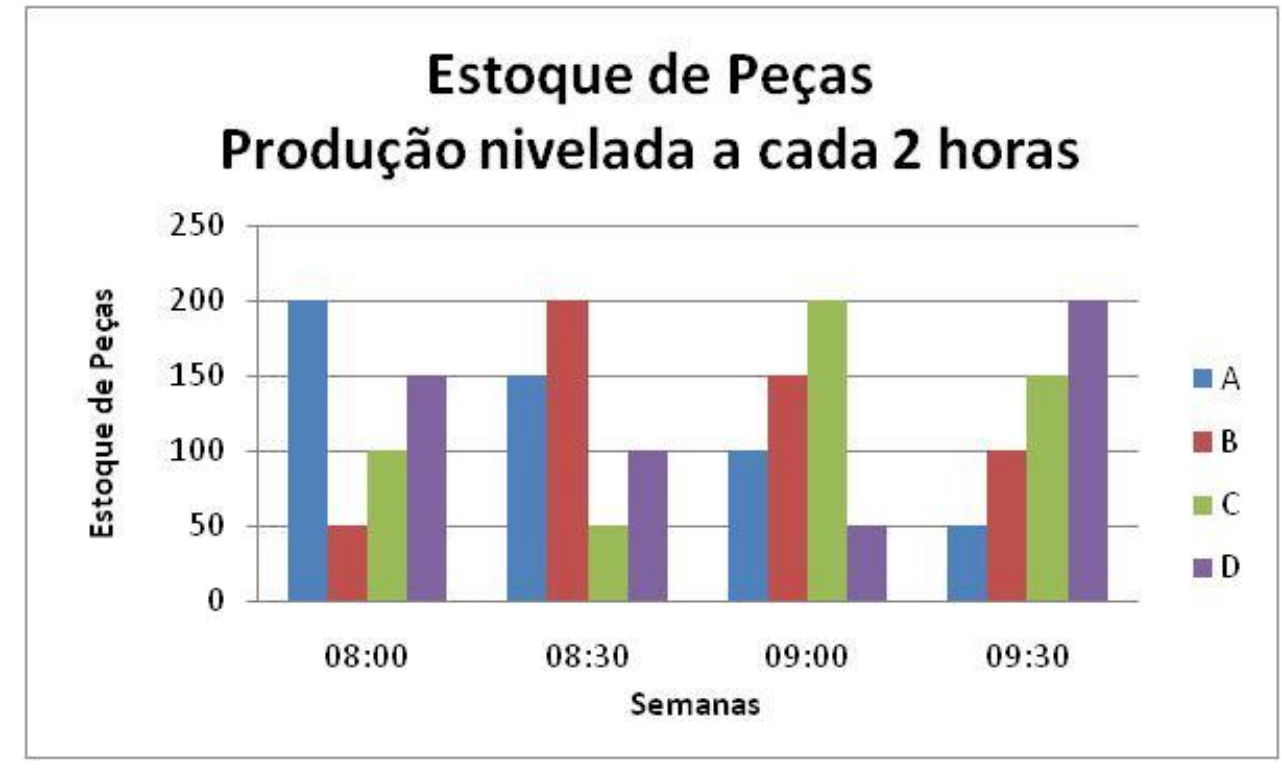

Gráfico 2 - Nível de estoque em uma produção nivelada a cada 2 horas

Fonte: Adaptado de Tardin (2001)

Dessa forma, quanto menor o intervalo em que todas as peças são produzidas mais nivelada é a produção. O nivelamento que acontece no processo puxador torna toda a carga do fluxo também uniforme (TARDIN, 2001).

Segundo Ohno (1997), “o STP, porém, exige produção nivelada e os menores lotes possíveis, mesmo que isso pareça contrário à sabedoria convencional”. Logo, "produzir em pequenos lotes significa que não podemos operar com uma prensa por muito tempo. Para responder à estonteante variedade dos tipos de produto, a matriz deve ser mudada com freqüência. Conseqüentemente, os procedimentos de troca de ferramentas devem ser executados rapidamente."

Porém, existe um limite para reduzir os lotes de produção no sistema, geralmente causado pelo tempo de setup dos equipamentos, e isto pode ser definido através do conceito de TPT. O TPT significa a freqüência com que cada peça é produzida em um processo. Por exemplo, se a cada quatro dias a peça é produzida em um processo então o TPT é de quatro dias. Quanto menor o TPT melhor será o nivelamento pois mais freqüentemente a peça poderá ser produzida e, dessa forma, menor será o lote produzido (LEAN ENTERPRISE INSTITUTE, 2007). 


\subsubsection{Takt time}

O conceito de takt time pode ser entendido como o ritmo que a fábrica deve seguir para conseguir atender a demanda dos clientes e pode ser calculado através da divisão do tempo disponível de trabalho com o volume de demanda do cliente, conforme Equação 1:

Equação 1 - Cálculo de takt time

$$
\text { Takt Time }=\frac{\text { Tempo de trabalho disponível por período }}{\text { Demanda do cliente por período }}
$$

Sendo assim, o takt time é utilizado para sincronizar o ritmo de produção com o ritmo de vendas e esse valor pode ser interpretado como o tempo máximo para produzir uma única peça, por em todos os recursos do fluxo de valor, a fim de atender toda a demanda do cliente (ROTHER e SHOOK, 1999).

Entretanto, o conceito de takt time não pode ser interpretado sozinho e sim contrastando-se esse valor com o tempo de ciclo dos produtos. O tempo de ciclo, segundo Rother e Shook (1999), "é o tempo transcorrido entre a saída de uma peça e a saída da seguinte".

Quando o tempo de ciclo é maior do que o takt time, a empresa não consegue atender à demanda do cliente. Já quando o tempo de ciclo é menor do que o takt time pode ocorrer o excesso de produção, pois é possível produzir mais do que a quantidade demandada pelos clientes.

O takt time, em um primeiro momento, não considera a capacidade de produção para ser calculado, pois os dados utilizados são apenas os dados de demanda e tempo disponível. Entretanto, a capacidade de um recurso pode fazer com que o valor assumido para o takt time seja alterado para um takt time efetivo, ou seja, aquele que é possível ser cumprido, caso não haja capacidade para cumprimento do takt time. Isso acontece quando o tempo de ciclo de um produto é maior que o takt time.

Nesse caso é possível dizer que o tempo de ciclo é um limitante do takt time. Ou, ainda, segundo Alvarez e Antunes Jr. (2001), o takt time efetivo é sempre limitado, seja pela capacidade (representada pelo tempo de ciclo), ou seja, pela demanda (representada pelo takt time calculado). 
Esse conceito deve estar vinculado ao processo de planejamento e controle da produção, pois é uma forma de evitar que o sistema seja sobrecarregado em momentos de pico mesmo tendo condições globais de atender a demanda do cliente. Ou ainda, a utilização do takt time na gestão do fluxo de materiais tem como objetivo clarear as oportunidades de melhoria para a fábrica, a partir da identificação dos processos que restringem a capacidade da fábrica (ALVAREZ e ANTUNES JR., 1999).

\subsubsection{Pitch}

O intervalo pitch representa o tempo necessário para o processo puxador produzir um contêiner de peças. O pitch é calculado multiplicando-se o takt time pela quantidade de peças em um contêiner.

Em um exemplo onde o takt time é de 54 segundos e cabem 10 peças em uma embalagem, o pitch é de 540 segundos (9 minutos), ou seja, a cada 9 minutos uma embalagem deverá ser programada. Dessa forma, é possível acompanhar se a produção está seguindo o ritmo determinado pelo takt time. Ou seja, com o conceito de pitch cada contêiner deve ser produzido a cada intervalo pitch (SMALLEY, 2004).

A utilização do conceito pitch é o primeiro passo para uma programação da produção nivelada, já que ele permite a criação de um senso de ritmo e também permite um controle visual de aderência à quantidade programada por turno.

\subsubsection{Heijunka Box}

O conceito de heijunka box surgiu na Toyota e sua primeira aplicação ocorreu no setor de manutenção a fim de criar uma gestão visual do trabalho que deveria ser realizado e disciplinar o ritmo de trabalho. A partir dessa primeira aplicação, foram criados os quadros para acompanhamento de produção (SMALLEY, 2004).

Tardin (2001) afirma que "os heijunka box são complementares ao sistema kanban, pois além de mostrarem a situação de estoque dos itens através dos cartões kanban ele também mostra o ritmo com que a produção deve seguir". 
A Figura 16 mostra um modelo típico de quadro de nivelamento da produção, onde os cartões kanban são posicionados nos espaços de tempo disponíveis (ARAUJO, 2009). Nesse modelo, cada linha horizontal apresenta um tipo de produto e cada coluna vertical representa intervalos de tempo onde serão programados os cartões kanban.

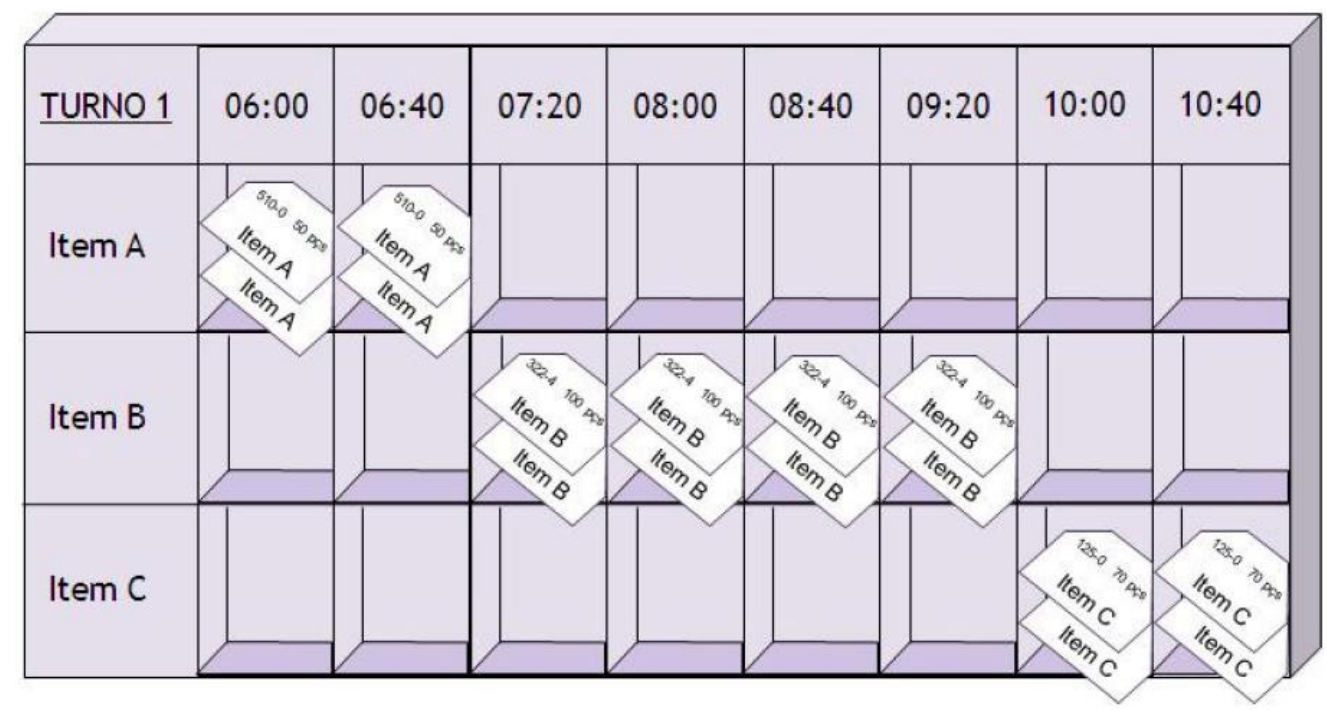

Figura 16 - Modelo de quadro de nivelamento da produção

Fonte: Araujo (2009, apud Smalley, 2004)

Cada espaço do quadro representa um pitch de produção, que é calculado pela multiplicação entre o takt time e a quantidade de peças por embalagem. No exemplo da Figura 16, um produto com pitch de 10 minutos deverá ser programado com 4 cartões por intervalo de tempo do quadro.

\subsubsection{Produção Puxada nos processos anteriores}

A produção puxada pode ser operacionalizada através de diversos sistemas puxados como sistema kanban e CONWIP (conforme apresentado nas seções 2.2.3 e 2.2.4, respectivamente), que são caracterizados pela limitação da quantidade de WIP através da utilização de cartões que acompanham as peças e disparam a produção (HOPP e SPEARMAN, 2004). 


\subsection{Quadro kanban}

Para gerenciar os cartões kanban que acompanham as peças são utilizados quadros que armazenam os cartões kanban quando estes não estão anexados às peças. O quadro kanban localiza-se próximo ao processo fornecedor.

Os quadros kanban são ferramentas complementares ao sistema kanban e são organizados a fim de informar os operadores sobre a situação do estoque (ou supermercado) dos itens e sobre quais itens devem ser priorizados na produção (TARDIN, 2001).

O quadro kanban é formado por três faixas coloridas (verde, amarelo e vermelho) e os cartões vão sendo colocados, conforme chegam ao quadro, da faixa verde, passando pela amarela e, por último, na faixa vermelha. Quando o operador produz determinada peça, um ou mais cartões referente a ela são retirados do quadro e anexados junto às peças. A retirada de cartões acontece no sentido inverso à colocação de cartões no quadro, ou seja, os cartões são retirados primeiro da faixa vermelha, depois da amarela e, por último, da faixa verde.

Um exemplo de quadro kanban é mostrado na Figura 17: 


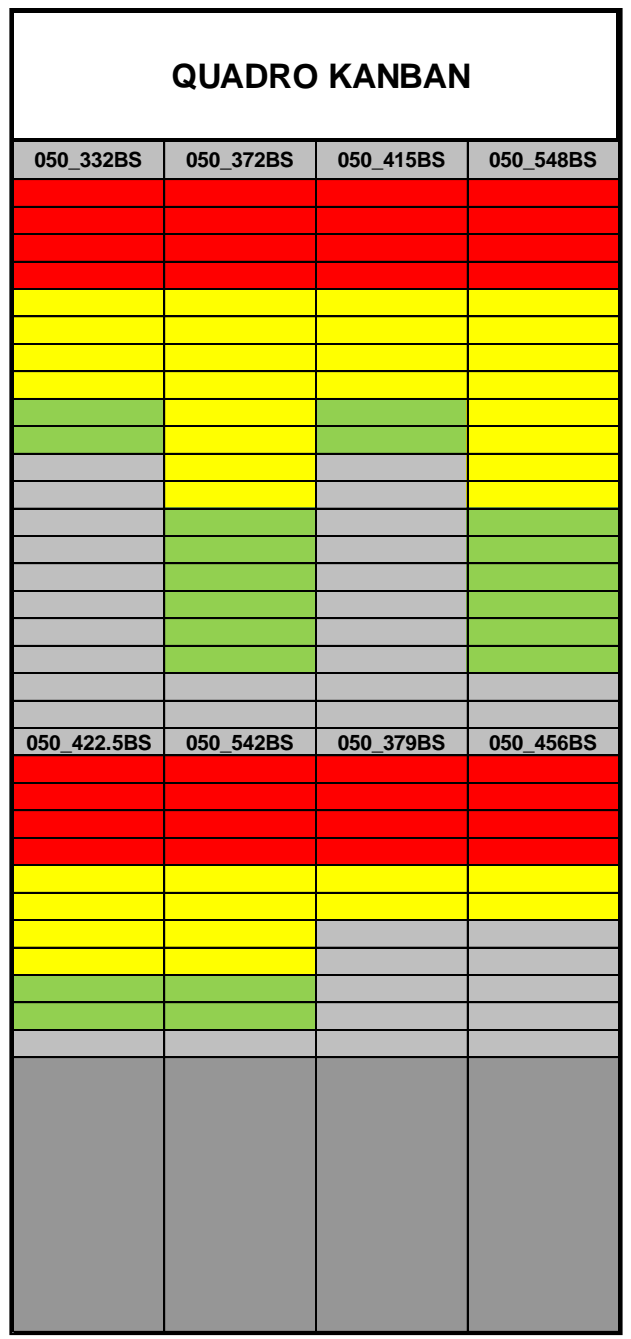

Figura 17 - Modelo de quadro kanban

Cada faixa colorida do quadro kanban é definida baseado no dimensionamento dos supermercados, que são os estoques dimensionados que estão presentes no sistema kanban. Para dimensioná-los, diversos autores apresentam formas de cálculo.

\subsection{Dimensionamento de supermercados}

Smalley (2004) propõe uma forma de cálculo que leva em consideração três tipos de estoques: estoque de ciclo, estoque pulmão e estoque de segurança, conforme mostrado na Figura 18.

O estoque de ciclo representa a quantidade de peças necessárias para atender a demanda média do produto e é calculado pela multiplicação entre o lead time de reposição do 
item e a sua demanda média diária. Já o estoque pulmão está presente para cobrir a variação de demanda do cliente e é calculado através do conceito estatístico de desvio padrão. Por fim, há o estoque de segurança, para cobrir a demanda quando há problemas internos como retrabalhos e quebras de máquinas e deve ser estimado de acordo com o tempo necessário da produção para responder aos problemas que ocorrem (SMALLEY, 2004).

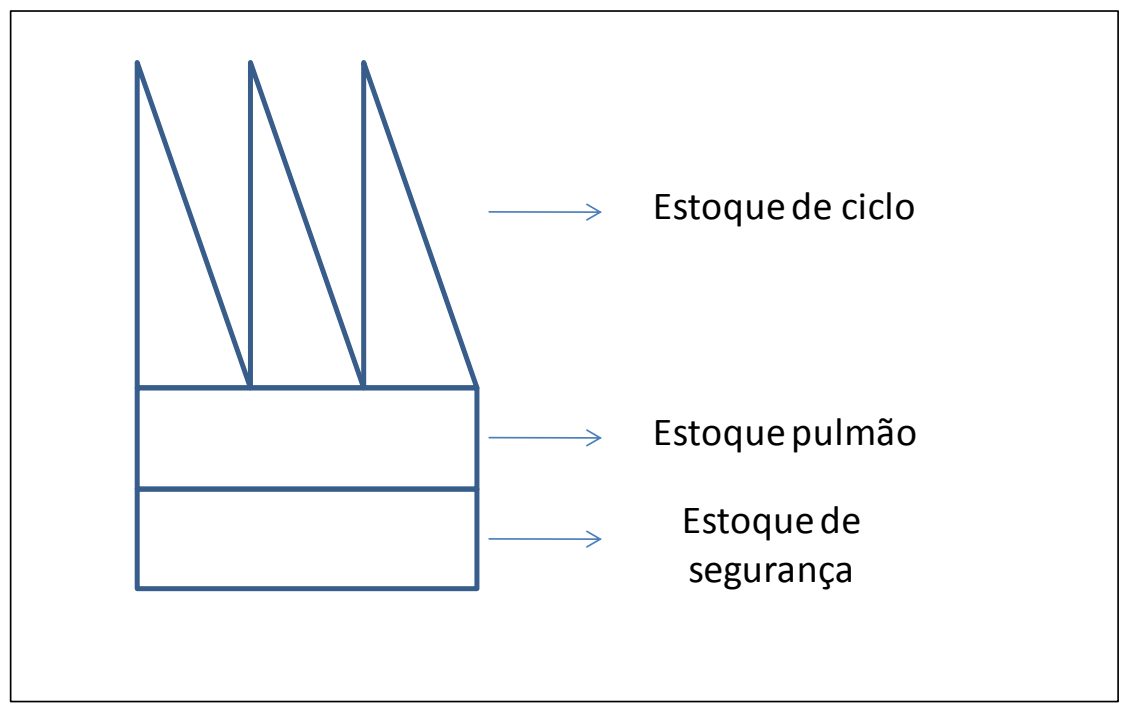

Figura 18 - Tipos de Estoques

Fonte: Adaptado de Smalley (2004)

Em seu trabalho, Nazareno (2008) aponta para o problema da alta variedade de itens que resulta em máquinas não dedicadas para uma família de produtos, pois as peças devem esperar em uma fila antes do processo produtor para serem produzidas.

Por esse motivo, Nazareno (2008) propõe considerar o TPT (ou EPEI, em inglês) que representa a frequência com que um item pode voltar a ser produzido em um determinado intervalo de tempo.

Nesse caso, Nazareno (2008) apresenta uma forma de cálculo que além de atender ao conceito apresentado por Smalley (2004), incorpora o conceito do TPT nos cálculos para dimensionamento dos supermercados. A Figura 19 mostra o dimensionamento proposto por Nazareno (2008). 


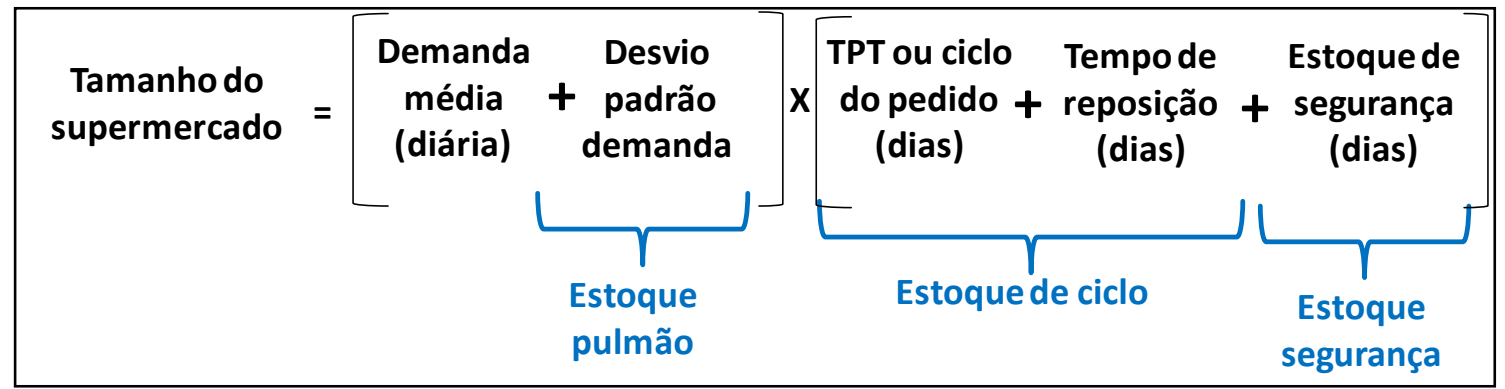

Figura 19 - Cálculo de dimensionamento de supermercados

Fonte: Adaptado de Nazareno (2008)

Outros autores também apresentam formas de dimensionamento em seus trabalhos, porém, neste trabalho, serão detalhados somente estes dois autores para o entendimento do assunto.

\subsection{Estabelecer padrão de atividades}

A implantação de um sistema puxado acompanha algumas regras para que o sistema funcione conforme planejado.

Uma delas se refere ao tipo de reposição do sistema kanban. Os tipos de reposição podem ser, segundo Nazareno (2008):

- Reposição por quantidade fixa: a reposição de um item deve acontecer sempre que o supermercado atingir um determinado nível. Nesse caso a quantidade reposta é fixa, mas o período entre reposições é variável.

- Reposição por ciclo dos pedidos constante: Cada item possui datas específicas para sua reposição de acordo com o TPT definido. Nesse caso, a cada data definida de reposição o item é produzido na quantidade de cartões disponíveis no quadro kanban. Nesse caso, o período entre reposições é fixo, mas a quantidade reposta é variável.

A segunda alternativa é normalmente utilizada em ambientes de alta variedade de produtos como uma alternativa para a reposição por quantidade fixa já que, segundo Nazareno (2008), “a reposição por quantidades fixas em ambientes com alta variedade tende a ser mais 
afetada pelo desnivelamento da demanda, resultando também no desnivelamento da produção".

Outras regras que devem ser executadas para que o sistema kanban funcione são, segundo Nazareno (2008, apud Monden, 1998):

Regra 1: O processo seguinte deve retirar produtos do processo anterior na quantidade necessária e no momento correto.

Regra 2: O processo anterior deve produzir produtos para o processo seguinte nas quantidades retiradas por este.

Regra 3: Produtos defeituosos nunca devem passar para os processos seguintes.

Regra 4: O número de kanbans deve ser minimizado.

Regra 5: O kanban deve ser usado para suportar pequenas variações na demanda.

\subsection{Produção puxada nos fornecedores}

$\mathrm{O}$ conceito de supermercado também pode ser estendido à matéria-prima. Nesse caso, o processo responsável por repor o supermercado é o próprio fornecedor de matériaprima.

O sistema puxado com os fornecedores é bastante similar ao sistema puxado de processos internos, com utilização de cartões e dimensionamento realizado da mesma maneira.

Uma diferença é que, geralmente, os cartões não são enviados aos fornecedores e a gerência dos supermercados é responsabilidade da equipe de PCP que identifica a necessidade de envio de pedidos aos fornecedores, recolhe os cartões do quadro kanban e envia pedidos de compra relativos aos itens e quantidades dos cartões kanban aos fornecedores.

Uma forma de controlar a entrega no prazo dos fornecedores é a utilização de um sistema de gestão visual onde é possível posicionar os cartões nas datas prometidas pelo fornecedor (e que atendam o lead time de reposição utilizado para dimensionamento dos supermercados) e acompanhar se os produtos foram entregues na data prometida. A partir 
deste tipo de quadro é possível levantar dados relativos à pontualidade de entrega dos fornecedores. O quadro utilizado para controle de recebimento dos fornecedores pode ser visualizado na Figura 20.

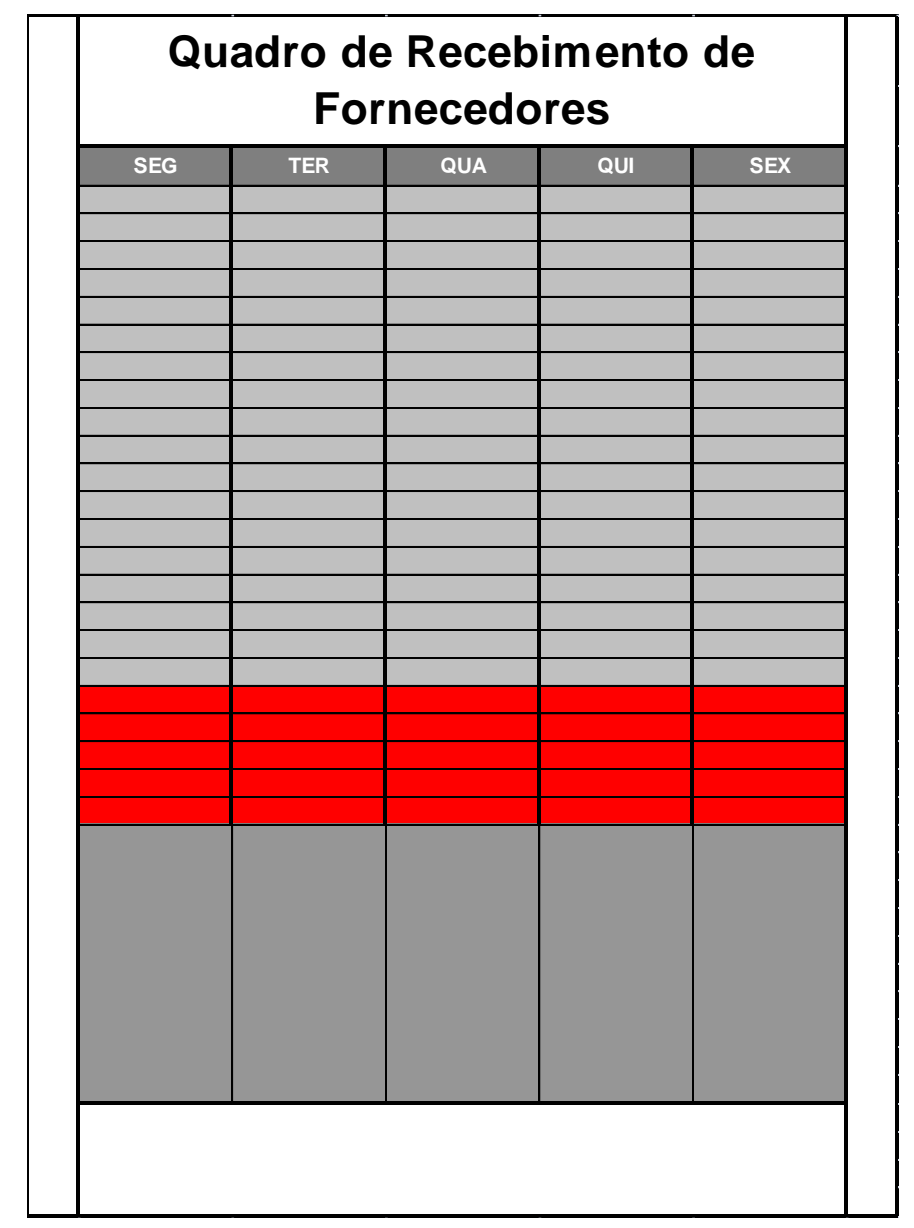

Figura 20 - Quadro de Recebimento de Fornecedores

No quadro mostrado na Figura 20, os cartões são posicionados na data prometida de entrega (por exemplo, um cartão com peças com data de entrega prometida pelo fornecedor para a próxima quarta-feira é posicionado nos espaços em cinza da coluna identificada como quarta-feira (QUA)). Sempre que uma peça é recebida, o cartão referente a ela é retirado do quadro e anexado à peça. Ao final de um dia, é checado se algum cartão (que deveria ter suas peças entregues naquele dia) ainda está posicionado no quadro, indicando que não foi entregue na data prometida pelo fornecedor. Nesse caso, o cartão restante é passado da faixa cinza para a faixa vermelha do mesmo dia, indicando que as peças referentes a esse cartão estão atrasadas. 


\subsubsection{Variantes do sistema tradicional}

A fórmula da produção enxuta é aplicada diretamente apenas em uma pequena proporção dos casos e muitas empresas devem ter cuidado ao utilizar as práticas da produção enxuta e se preocupar em adaptá-las às suas necessidades específicas (JINA; BHATTACHARYA; WALTON, 1995).

Para atender às necessidades e características específicas que não permitem a aplicação da abordagem tradicional de produção enxuta surgem algumas variantes do sistema, que permite que o conceito seja aplicado, porém com ferramentas adaptadas a cada situação.

Entre essas variantes podemos citar a programação da produção para ambientes com alta variedade de produtos e sistemas híbridos (sistemas puxados e empurrados operando conjuntamente).

Há outras diversas variantes, porém somente essas serão discutidas para a realização deste trabalho.

\subsection{Sistemas híbridos puxado e empurrado}

Um sistema híbrido acontece quando, em um mesmo fluxo de valor, são adotados diferentes sistemas de PCP como ordem e sistema kanban (RENTES, 2005). A Figura 21 mostra parte de um fluxo de valor onde é possível verificar que há duas diferentes subfamílias de programação e controle. A primeira delas (subfamília A) é controlada via ordens de produção e a segunda (subfamília B) é controlada via sistema puxado. Nesse caso, o processo mostrado produz tanto para ordens de produção quanto para reposição de supermercado. 


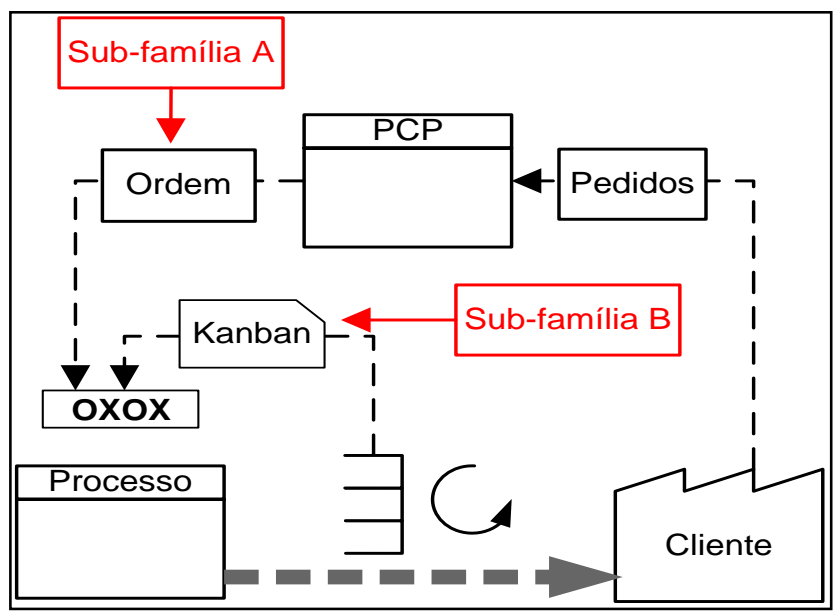

Figura 21 - Exemplo de um sistema híbrido

Fonte: Adaptado de Rentes (2005)

Nesse tipo de ambientes com os dois sistemas de PCP trabalhando de forma complementar, normalmente, os itens mais representativos (com maior demanda) são controlados via sistema kanban, enquanto que os outros produtos são produzidos somente mediante pedidos dos clientes.

\subsection{Programação para mix de alta variedade de produtos}

Há uma demanda crescente, no mercado atual, de clientes que exigem produtos cada vez mais customizados. Nesse ambiente, a estratégia de produção mais comum para atender a essa alta variedade de produtos é o MTO, em que o produto é produzido somente quando o pedido do cliente é efetuado ou ainda ETO, em que o produto é desenvolvido somente quando o pedido do cliente é efetuado (BOKHORST e SLOMP, 2007).

Uma empresa que busca competitividade não pode abrir mão de sua alta variedade de produtos, pois precisa estar apta a atender as mais variadas necessidades de seus clientes (HÜTTMEIR et al., 2006).

Para Lage e Godinho (2006), a alta variedade de produtos é uma das condições desfavoráveis à implantação dos sistemas puxados de produção, mais especificamente, do sistema kanban, pois "aumenta a complexidade do fluxo de materiais, dificulta a adaptação dos painéis de cartões, cria irregularidades nos tempos e diminui a repetibilidade do sistema produtivo". 


\subsubsection{Nivelamento do processo puxador para ambientes de alta variedade de produtos}

Assim como nos outros ambientes de produção, um ambiente com alta variedade de produtos também possui a necessidade de produzir de forma nivelada, já que, segundo Jones (2006), o nivelamento é verdadeiramente essencial para criar um sistema de produção enxuta, pois é a chave para a estabilidade.

Adiante serão detalhados alguns aspectos de nivelamento de produção para este tipo de ambiente.

\subsubsection{Takt time para ambientes com alta variedade de produtos}

Uma característica comum em situações de alta variedade de produtos, devido aos diferentes produtos vendidos pela empresa, é a variabilidade do tempo de ciclo (BOKHORST e SLOMP, 2007).

Uma das limitações no uso do conceito de takt time está em ambientes em que os diferentes produtos não possuem tempos de ciclo idênticos (ROTARU, 2008).

Quando há alta variabilidade de tempo de ciclo o controle do takt time se torna difícil já que o takt time mostra um ritmo médio com que todos os produtos devem ser produzidos. $\mathrm{Na}$ comparação do takt time médio com o tempo de ciclo (conforme mostrado na Seção 2.3.3.1.1), a análise pode se tornar distorcida. A Tabela 4 mostra um exemplo da distorção que pode ocorrer: 
Tabela 4 - Exemplo de takt time para produtos com variação de tempo de ciclo

\begin{tabular}{|c|c|c|c|}
\hline Produto & T/C (s) & $\begin{array}{c}\text { Demanda } \\
\text { diária (peças) }\end{array}$ & Takt time (s) \\
\hline A & 3 & 1000 & \multirow{2}{*}{11,7} \\
\hline B & 10 & 500 & \multirow{2}{*}{11,7} \\
\hline C & 15 & 400 & \\
\hline D & 20 & 800 & \\
\hline
\end{tabular}

De acordo com a Tabela 4, se, quando o produto A estiver sendo produzido, o ritmo de produção for de cerca de 12 segundos, o tempo de ciclo estará condizente com o takt time, porém, não haverá tempo disponível para produzir toda a demanda diária dos outros itens naquele dia. Em contrapartida, no momento em que estiver sendo produzido o produto D, o processo não estará trabalhando no ritmo desejado, já que o tempo de ciclo do produto D é 20 segundos e o takt time é cerca de 12 segundos.

Bokhorst, Slomp e Germs (2009) propõem uma forma alternativa ao conceito tradicional de takt time com o objetivo de reduzir a dificuldade no controle do takt time em ambientes com variação de tempo de ciclo. A proposta dos autores é adaptar o conceito de takt time calculando-o para uma unidade de produção ao invés de para uma peça. Nesse caso, ao invés de controlar o tempo de processamento peça a peça, é controlado o tempo de processamento a cada unidade de produção.

\subsubsection{Heijunka como ferramenta de programação}

Além da função de nivelamento da produção, o quadro heijunka pode ser utilizado também como um quadro de programação.

O quadro heijunka possui a função de programação da produção além da função de nivelamento, pois permite que os operadores programem a produção. Além disso, sua utilização permite enxergar alguns problemas como excesso de inventário, longos setups, quebras constantes, falta de material e outros problemas (TARDIN e LIMA, 2000). 


\subsubsection{Modelos de programação nivelada da produção para ambientes com alta variedade de produtos}

$\mathrm{Na}$ literatura estudada, alguns modelos de nivelamento de produção foram identificados e serão detalhados adiante.

\section{Modelo 1}

O trabalho de Bokhorst, Slomp e Germs (2009) apresenta um modelo de nivelamento de produção para ambientes com alta variedade de produtos. Esse modelo se baseia em três conceitos básicos da programação e controle da produção em ambientes enxutos. São eles: nivelamento de produção, uso de sistemas puxados e controle do takt time.

O modelo proposto pelos autores faz uma adaptação aos modelos tradicionais dos conceitos de programação e controle da produção em ambientes enxutos com o objetivo de aplicá-los em ambientes com alta variedade de produtos.

O sistema puxado de produção utilizado no modelo foi o CONWIP.

Segundo Bokhorst, Slomp e Germs (2009), a alta variedade de produtos implica, normalmente, em produtos, com diferentes sequiências de produção e diferentes tempos de ciclo, que utilizam um mesmo sistema produtivo. Nesse caso, a utilização do conceito puro de takt time se torna complexo, conforme foi discutido anteriormente na Seção 2.2.7.3..

Para contornar essa característica que torna complexa a utilização do conceito puro de takt time, os autores propõem uma adaptação ao conceito. Nessa adaptação, o takt time não é mais calculado por peça e sim por unidade de produção, que representa certa quantidade de peças através de cartões. Nesse caso, as ordens entram e saem do sistema produtivo de acordo com o takt time e seguindo uma seqüência FIFO.

Para operacionalizar a utilização do CONWIP são utilizados cartões que acompanham as peças e são a forma de limitar o WIP. O lead time esperado para cada cartão, conforme apresentado na Equação 2, é o WIP multiplicado pelo takt time, ou seja, se a cada período representado pelo takt time deve sair um cartão e há uma certa quantidade de cartões no sistema, então cada cartão demora para atravessar o fluxo o tempo representado por essa multiplicação. 
Equação 2 - Lead time esperado para o método CONWIP

\section{Lead time $=$ WIP $\times$ Takt time}

A implantação do sistema, conforme apresentado no artigo, foi realizada em três fases, sendo a primeira responsável por implantar o método CONWIP, a segunda responsável por criar a seqüência FIFO e a terceira por controlar o takt time.

A fase 1 foi realizada definindo-se a quantidade máxima de WIP e confeccionando cartões numerados em seqüência para serem anexados às peças que estavam sendo produzidas. Dessa forma, toda peça em processo no fluxo deve ter um cartão acompanhandoa. Ao terminar o processamento das peças que representam um cartão, esse cartão é devolvido ao início do fluxo e, assim que possível, anexado à próxima ordem a ser produzida.

A fase 2 foi implantada e permitiu que os operadores processassem a ordem mais antiga antes de processar uma ordem mais nova através de uma linha FIFO controlada pela data e horário de entrada de uma ordem no sistema. Com essa fase, os operadores não poderiam mais ignorar as ordens mais difíceis de serem produzidas. Dessa forma, as ordens mais antigas aparecem como prioridade de produção.

Para auxiliar os operadores na priorização das ordens mais antigas foi instalado um sistema de gestão visual denominado "quadro de progresso da produção", inicialmente montado via planilha eletrônica, apresentado na Figura 22 com o objetivo de visualizar quais ordens deveriam ser priorizadas de acordo com o tempo transcorrido desde sua entrada na produção.

Pode-se notar, na Figura 22, que o "quadro de progresso da produção" apresenta, no seu lado esquerdo, alguns indicadores como horário atual e takt time e, na parte direita, todas as ordens em processo no fluxo relacionadas com os 60 cartões utilizados no método CONWIP, numerados de 1 a 60 e relacionados com o tempo desde a entrada da ordem no fluxo. Por exemplo, o cartão número 48 está relacionado com uma ordem que está há 27 horas e 39 minutos no fluxo.

Ainda é possível notar na Figura 22 que os cartões são ordenados em ordem decrescente de acordo com o tempo desde a entrada da ordem no fluxo. Dessa forma, os operadores identificam claramente quais cartões devem ser priorizados na produção. 


\begin{tabular}{|c|c|c|c|c|}
\hline \multirow{2}{*}{$9: 17: 00$} & 48 || 27:39 & 37|| $14: 31$ & 21|| $09: 08$ & 04 || 03:46 \\
\hline & 42|| $25: 26$ & 43|| $14: 12$ & 41|| $08: 44$ & 55 || 03:25 \\
\hline To be Produced & 22|| $24: 34$ & 32|| $13: 52$ & 33|| $08: 18$ & 06|| || 03:02 \\
\hline \multirow{2}{*}{46} & 09 || 22:47 & 58|| $13: 32$ & 39 || 08:00 & 14|| $02: 38$ \\
\hline & 27|| $20: 59$ & 60|| $13: 10$ & 31|| $07: 42$ & 17|| $02: 13$ \\
\hline \multirow{2}{*}{ Finished Products } & 16|| $18: 02$ & 49 || 12:47 & 23|| $07: 22$ & 28|| $01: 48$ \\
\hline & 07|| $17: 46$ & 53|| $12: 24$ & 02|| $07: 01$ & 24|| $01: 30$ \\
\hline \multirow[t]{2}{*}{4} & 08|| $17: 27$ & 12|| $11: 59$ & 40|| $06: 40$ & 13|| $01: 11$ \\
\hline & 52 || 17:07 & 38|| $11: 33$ & 01|| $06: 17$ & 05 || 00:52 \\
\hline Lead/ backlog: & 45|| $16: 47$ & 46|| $11: 16$ & 57|| $05: 53$ & 59|| $00: 31$ \\
\hline \multirow[t]{2}{*}{1} & 10|| $16: 25$ & 29 || 10:57 & 51|| $05: 29$ & 47 || 00:09 \\
\hline & 56|| $16: 02$ & 30|| $10: 37$ & 50|| $05: 03$ & 18 || 00:03 \\
\hline Takttime (minutes) & 44|| $15: 39$ & 25|| $10: 17$ & 19 || 04:45 & 35 || --:-- \\
\hline \multirow[t]{2}{*}{$00: 20$} & 36|| $15: 14$ & 03 || 09:55 & 26|| $04: 27$ & 20 || --:-- \\
\hline & 11|| $14: 48$ & 15 || 09:32 & 54|| $04: 07$ & 34 || --:-- \\
\hline
\end{tabular}

Figura 22 - Quadro de progresso da produção

Fonte: BOKHORST; SLOMP; GERMS (2009)

A fase 3 foi implantada calculando-se o takt time e definindo através da quantidade máxima de WIP e da Equação 2, qual seria o lead time esperado para uma ordem de produção. No exemplo apresentado pelos autores, o takt time é de 20 minutos por cartão e o WIP máximo é de 60 cartões, o que resultado em um lead time esperado de 20 horas (20 minutos/cartão * 60 cartões).

Com o lead time esperado calculado, é possível visualizar, no quadro apresentado na Figura 22 quais cartões representam ordens atrasadas (que estão marcados com a cor vermelha) pois o tempo transcorrido desde sua entrada no sistema é de mais de 20 horas.

Nessa fase foi implantada a rotina de, para cada ordem concluída após o prazo de 20 horas, apontar uma causa para esse problema. A geração desses dados permitiu que os gerentes e supervisores estudassem formas de reduzir as principais causas de atraso.

O responsável pelo planejamento deveria manter uma certa quantidade de pedidos em fila para evitar que cartões do CONWIP ficassem sem utilização. Porém, conforme pode ser visualizado na Figura 22, alguns cartões não possuem lead time apontados no quadro já que não possuem ordens anexadas a eles (como é possível observar nos 3 cartões na parte debaixo e a direita do quadro, com letras azuis). 
Pelo problema apresentado, foi projetada uma função de nivelamento ao modelo de forma a evitar que cartões fiquem sem utilização. Nesse caso, o programador é responsável por manter um buffer de ordens esperando cartões disponíveis para entrar no sistema de cerca de 2,5 dias de trabalho.

O modelo apresentado pelos autores exemplifica como os conceitos de produção enxuta, em especial o nivelamento de produção, sistema puxado de produção e controle do takt time podem ser adaptados para trazerem resultados benéficos para ambientes com alta variedade de produtos.

\section{Modelo 2}

Tardin (2001) propõe um modelo de nivelamento de produção que tem como base um quadro de nivelamento.

O método proposto inicia-se pela etapa de dimensionamento onde foi calculado o número de cartões kanban para cada item. Como esta parte do modelo não é relevante para o trabalho, ela não será discutida.

O segundo passo é definir um quadro de nivelamento da produção. O quadro proposto pelo autor é mostrado na Figura 23 e é dividido em duas partes, a primeira delas (na parte de cima do quadro), denominada Ordem de Produção, é a régua do tempo onde serão colocados os cartões que deverão ser produzidos durante o dia. A segunda parte (na parte debaixo do quadro) é onde serão colocados os cartões kanban referentes às peças.

A parte destinada aos cartões kanban, denominada "Situação do Estoque", é dividida de acordo com os itens que possuem cartões e, para cada um destes itens, há uma faixa verde, uma faixa amarela e uma faixa vermelha, cada uma delas com o tamanho suficiente para caberem todos os cartões definidos na etapa de dimensionamento. 


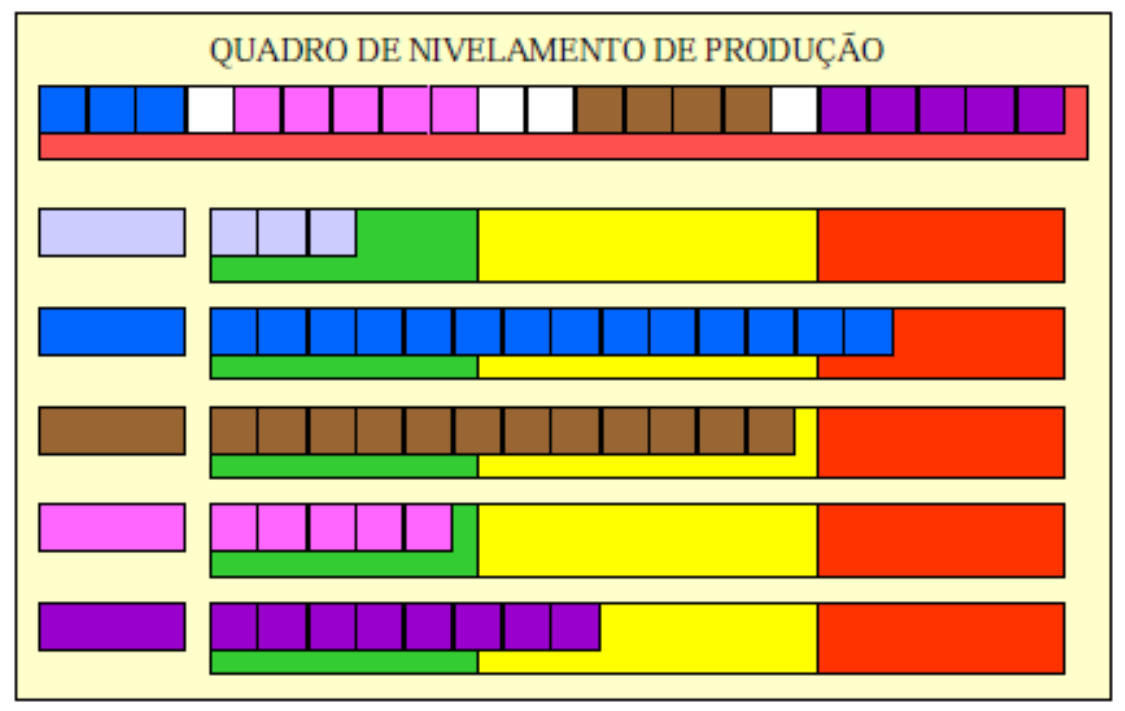

Figura 23 - Modelo de quadro de nivelamento de produção

Fonte: Tardin e Lima (2000)

À medida que as peças do supermercado forem consumidas, os cartões referentes a elas irão para o quadro, na parte de Situação do Estoque. Os cartões devem ser colocados nos espaços reservados para a peça sempre respeitando a ordem de colocação dos cartões da esquerda para a direita, ou seja, da faixa verde para a faixa vermelha.

A decisão sobre qual peça produzir se dará pela observação de qual peça tem cartões mais próximos da faixa vermelha.

Assim que o operador decidir qual peça deverá ser produzida, ele retirará os cartões da parte de Situação do Estoque e colocará na parte de Ordem de Produção, indicando a necessidade de produzir o item naquele dia, até completar a capacidade de produção diária, que acontecerá caso todos os espaços disponíveis na parte de Ordem de Produção estejam preenchidos.

O quadro apresentado pelo autor, além da função de nivelamento, apresenta a função de quadro de programação, já que mostra aos operadores quais peças devem ser produzidas ao longo do dia.

Há dois fatores que acontecem em um número significativo de sistemas produtivos e que dificultam a aplicação do modelo mostrado na Figura 23. O primeiro fator refere-se aos 
tempos de processamento diferentes para os produtos e o segundo fator refere-se aos tamanhos de embalagens diferentes, o que implica em diferentes valores para o pitch (TARDIN, 2001).

Além disso, as paradas programadas da produção (como almoço, reuniões e tempos de preparação (ou tempo de setup) das máquinas, não são considerados no modelo de quadro apresentado na Figura 23.

Para atender os pontos levantados anteriormente, Tardin (2001) apresenta o modelo de quadro de nivelamento mostrado na Figura 24, na qual é possível notar que existem cartões de diferentes larguras. A largura de cada cartão é proporcional ao tempo necessário para processamento das peças que o cartão representa.

Há, ainda, cartões que representam as paradas programadas (como refeições, reuniões e setup) com larguras correspondentes ao tempo da parada. Na Figura 24 estão mostrados alguns cartões (em cinza) que representam estas paradas.

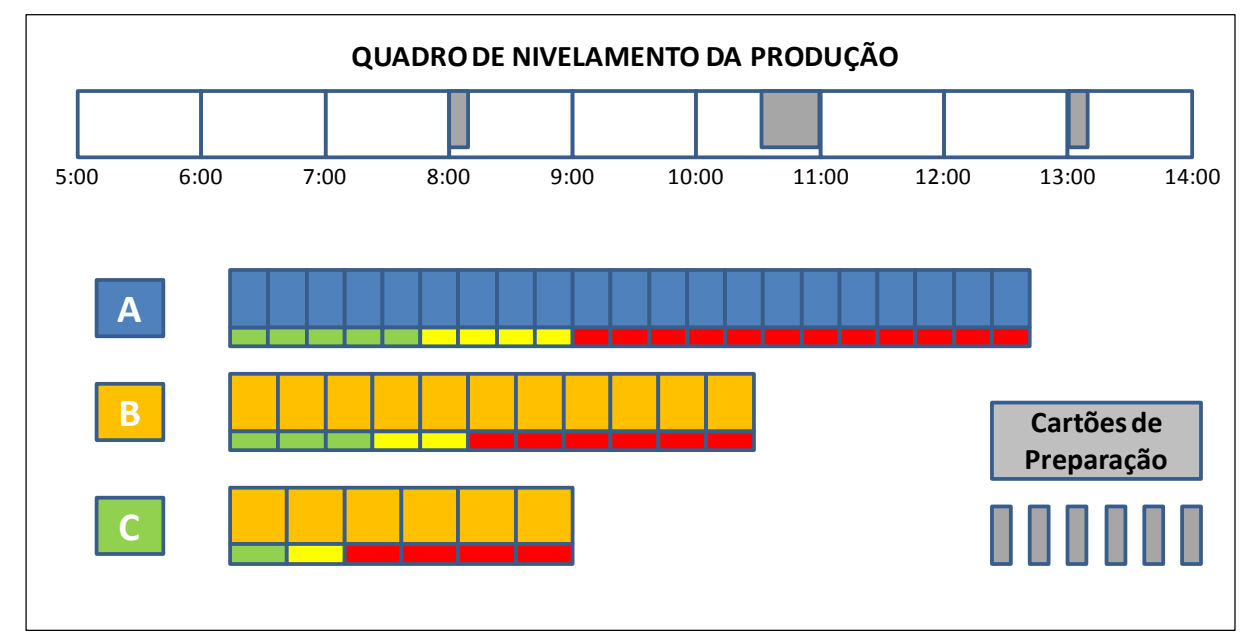

Figura 24 - Modelo de quadro de nivelamento da produção proposto por Tardin (2001)

Fonte: Adaptado de Tardin (2001)

Tardin (2001) utiliza o conceito de pontos como uma forma de normalização dos tempos de ciclo com o objetivo de uma clara relação entre os tempos de ciclo dos diferentes produtos. Por exemplo, um cartão referente ao item A da Figura 24 possui o valor de 6 pontos, enquanto que o cartão referente ao item B representa 7 pontos e o cartão referente ao item C representa 8 pontos, ou seja, o cartão do item C demora cerca de $33 \%$ a mais do que o cartão do item B para ser processado. 
É possível verificar na Figura 24 que os cartões referentes aos diferentes itens e às paradas programadas possuem larguras distintas. A largura de cada cartão é correspondente aos pontos que ele representa. Isso permite uma melhor alocação dos cartões no quadro já que cartões que representam mais pontos, e conseqüentemente, levam mais tempo para serem processados, ocupam uma área maior do quadro. Assim como dito anteriormente que o cartão do item C demora cerca de $33 \%$ a mais do que o cartão do item B para ser processado, o cartão do item $\mathrm{C}$ possui largura $33 \%$ maior do que o cartão do item $\mathrm{B}$.

A capacidade dos processos também é calculada em pontos com o objetivo de realizar a programação nivelada da produção, alocando uma quantidade em pontos para ser produzida em um dia compatível com a capacidade em pontos por dia de produção.

O modelo apresentado por Tardin (2001) é aplicável a mais casos do que os modelos tradicionais já que pode ser utilizado em ambientes que possuem alta variedade de produtos e variação nos tempos de ciclo das peças.

\section{Modelo 3}

O último modelo apresentado neste trabalho é o descrito por Araújo (2009). O modelo apresentado pelo autor possui a estrutura mostrada na Figura 25.

No modelo de programação nivelada, as informações de necessidades são passadas ao sistema através da relação de ordens de produção (para produtos não controlados via sistema kanban) e pelo quadro kanban (para os produtos controlados via sistema kanban). Além das necessidades, há um banco de dados sobre os produtos e um banco de dados sobre o recurso a ser programado de maneira nivelada que são dados de entrada para uma planilha eletrônica de nivelamento. 


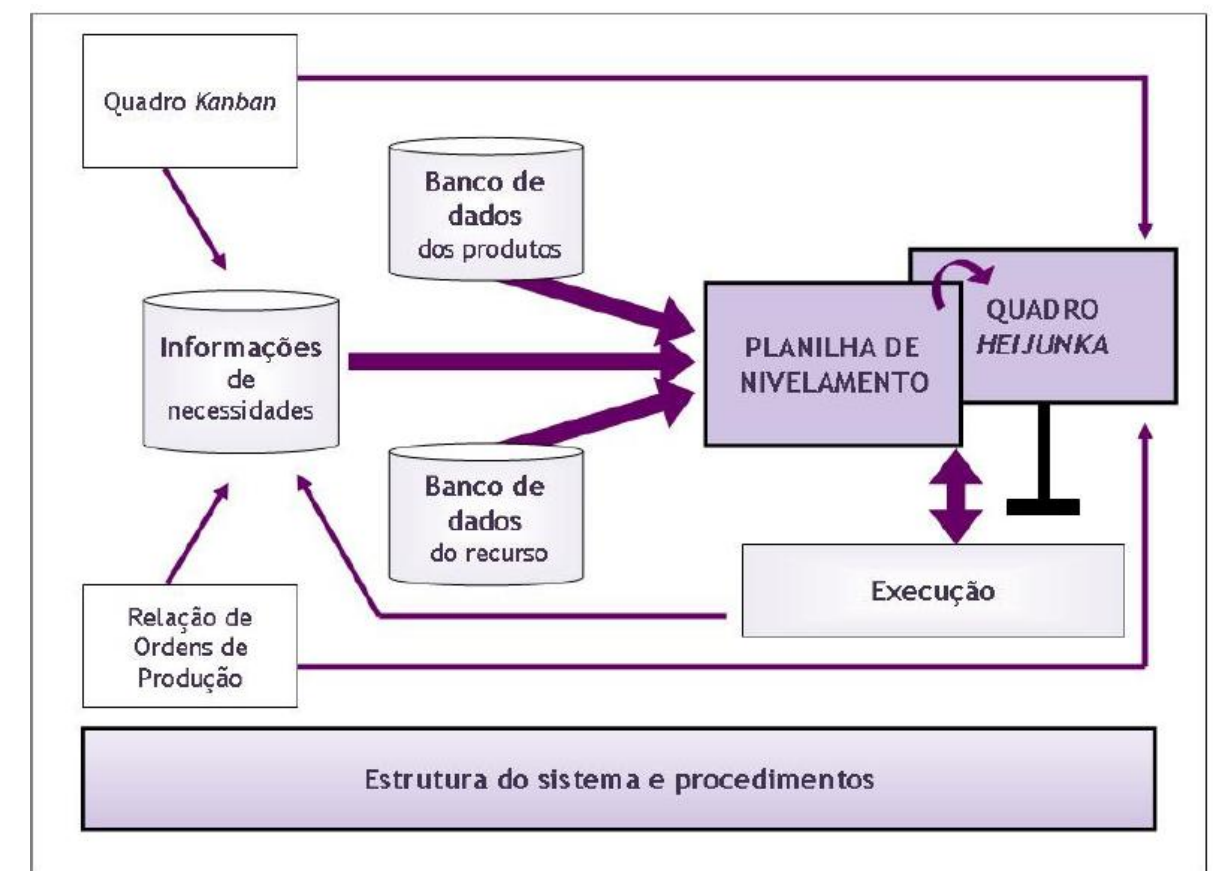

Figura 25 - Estrutura do modelo de nivelamento da produção proposto por Araujo (2009)

Fonte: Araujo (2009)

A planilha de nivelamento, mostrada de forma macro na Figura 26, é utilizada para listar, dia a dia, quais itens deverão ser processados no recurso e os setups que devem ser realizados entre o processamento de dois itens diferentes.

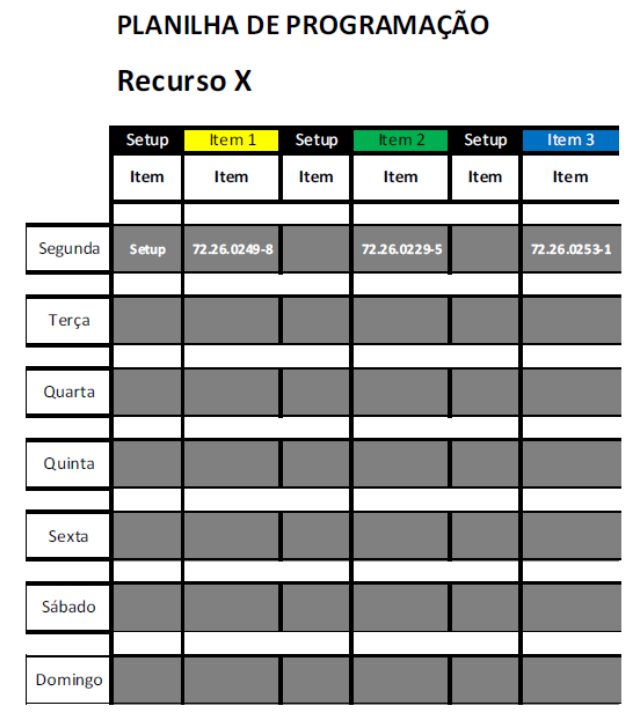

Figura 26 - Planilha macro de nivelamento da produção

Fonte: Araujo (2009) 
De forma mais detalhada, ao preencher a planilha, o programador deve inserir algumas informações sobre os itens que deverão ser programados, como código do item, quantidade de peças a serem programadas e número da ordem de produção ou número de kanbans caso o item seja controlado via sistema kanban, conforme Figura 27. Através de uma busca simples no banco de dados dos produtos, as informações sobre peças por hora produzidas no recurso e tipo de controle do item (kanban ou ordem) são colocadas na planilha.

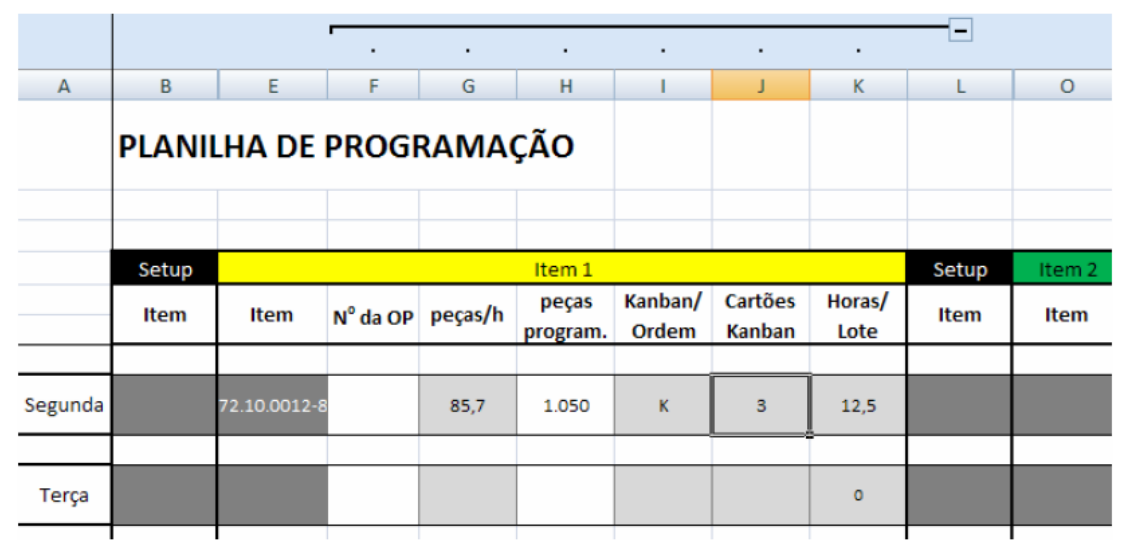

Figura 27 - Detalhe da planilha de nivelamento da produção

Fonte: Araujo (2009)

A partir da quantidade de peças a serem programadas e das peças por hora produzidas no recurso é calculado o tempo necessário, em horas, para produzir o lote, conforme pode ser visto na coluna "K" da planilha mostrada na Figura 27.

Com os tempos necessários para produção dos lotes de todos os itens, a planilha, a partir desses dados, preenche um quadro de nivelamento. Na Figura 28 está apresentado o quadro de nivelamento formado a partir da planilha mostrada na Figura 27. O quadro de nivelamento mostra qual o total de horas programadas em cada dia da semana e mostra o preenchimento de cada pitch de 30 minutos. 


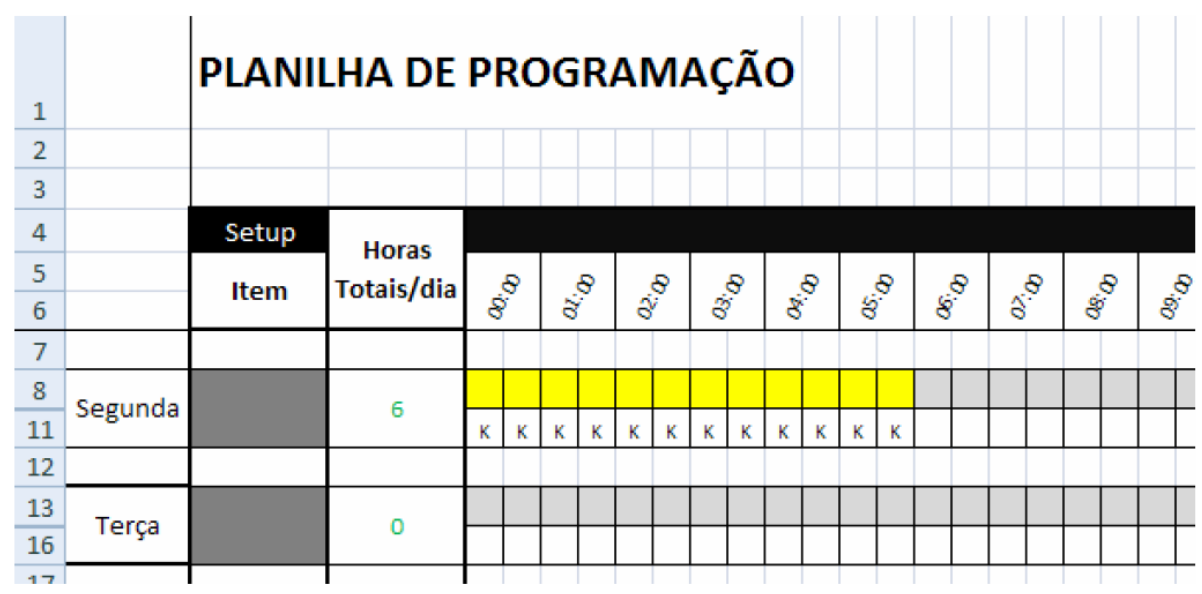

Figura 28 - Quadro de nivelamento da produção

Fonte: Araujo (2009)

Além dos tempos de processamento de itens e tempos de setup, outras paradas programadas, como manutenção preventiva, também podem ser programadas utilizando a ferramenta.

Com as informações inseridas na planilha, diariamente, o programador imprime o quadro de nivelamento gerado pela ferramenta e o disponibiliza no recurso para que os operadores consultem o quadro de nivelamento e verifiquem o que deve ser produzido durante todo o dia.

\subsubsection{Nivelamento do processo puxador em ambiente ETO}

Uma das estratégias de produção que uma empresa pode adotar é o Engineer to order (ETO), onde os pedidos dos clientes disparam o desenvolvimento ou alteração do projeto do produto.

Em um ambiente ETO, assim como em outros ambientes de manufatura, os benefícios trazidos pelo nivelamento da produção também são importantes e o nivelamento da produção pode e deve ser realizado.

Em um ambiente ETO, em que os produtos são produzidos de acordo com as especificações do cliente, os produtos normalmente são únicos. Dessa forma, por nunca terem 
sido processados, muitas vezes, não há dados históricos de produção sobre esses produtos, como tempos de processamento (tempos de ciclo) para esses itens, por exemplo.

Sem conhecer o tempo de processamento dos itens nos processos, se torna mais complexo implantar os conceitos de produção enxuta, como kanban, nivelamento de produção e takt time.

Mesmo que seja realizado um estudo de tempos a fim de coletar os dados sobre os tempos de processamento não será possível coletar todos os dados necessários, pois a especificação do produto é extremamente variada em um ambiente ETO (LEITÃO, BENAMOR, MECENA, 2007).

Visto que o conhecimento dos tempos de processamento é importante para o processo de planejamento e programação da produção e sua coleta é bastante complexa em um ambiente ETO, uma solução proposta é realizar um processo de estimativa de tempos de processamento. Esse processo é realizado na seguinte seqüência (LEITÃO, BENAMOR, MECENA, 2007):

- É realizada a coleta de tempos de processamento para alguns produtos;

- São definidas as variáveis desses produtos que interferem nos tempos de processamento (como espessura, peso, comprimento, por exemplo);

- É elaborada uma fórmula matemática que relaciona as variáveis dos produtos a fim de estimar o tempo de processamento para outros produtos cujos tempos de processamento não foram coletados;

- Por fim, é checada a variação entre tempos de processamentos calculados pela fórmula definida e medidos no processo com o objetivo de verificar a margem de erro da fórmula.

A partir da análise dos modelos de programação nivelada da produção para alta variedade de produtos estudados, é possível verificar quais apresentam algumas características específicas importantes para o nivelamento da produção no ambiente de produção estudado neste trabalho. As características e os autores referentes a cada uma delas são apresentados na Tabela 5: 
Tabela 5 - Relação entre características de um modelo de programação nivelada da produção para alta variedade de produtos e autores

\begin{tabular}{|l|c|c|c|}
\cline { 2 - 4 } \multicolumn{1}{c|}{} & $\begin{array}{c}\text { Adaptação a ambientes } \\
\text { com alta variação de } \\
\text { tempos de ciclo }\end{array}$ & $\begin{array}{c}\text { Controle do takt time } \\
\text { adaptado a ambientes } \\
\text { com alta variação de } \\
\text { tempos de ciclo }\end{array}$ & $\begin{array}{c}\text { Estimativa de tempos } \\
\text { de ciclo para ambientes } \\
\text { onde os tempos são } \\
\text { desconhecidos }\end{array}$ \\
\hline Araujo (2009) & $\mathrm{X}$ & $\mathrm{X}$ & \\
\hline $\begin{array}{l}\text { Bokhorst, Slomp e } \\
\text { Germs (2009) }\end{array}$ & $\mathrm{X}$ & & \\
\hline Tardin (2001) & $\mathrm{X}$ & & \\
\hline
\end{tabular}

Como pode ser observado na Tabela 5, nenhum autor estudado apresenta uma estimativa de tempos de ciclo em seus modelos de programação nivelada da produção. Para atender a essa característica, foi apresentado um modelo de estimativa de tempos de ciclo proposto por LEITÃO, BENAMOR, MECENA (2007).

A seguir será apresentado o Capítulo 3 deste trabalho que mostra o modelo proposto. 


\section{CAPÍTULO 3 - MODELO DE PROGRAMACÃO NIVELADA DA PRODUÇÃO}

Esse capítulo visa apresentar o modelo de programação da produção nivelada proposto pelo autora.

Inicialmente serão descritas brevemente as características do ambiente de produção estudado.

Por fim, é apresentado o modelo de programação da produção nivelada para diversas situações de posicionamento do recurso restrição (RRC) em relação ao processo puxador.

\subsection{Nivelamento do processo puxador para ambiente Engineer to Order com alta variedade de produtos}

Ambientes Engineer to Order (ETO) com alta variedade de produtos apresentam dificuldades comuns aos ambientes de alta variedade, como alta variação nos tempos de ciclo dos diferentes produtos do mix, e ainda podem apresentar a característica de desconhecimento do tempo de ciclo, onde é preciso trabalhar com estimativas para estes tempos, já que, muitas vezes, não há histórico de produção para um produto ETO.

Apesar das características citadas anteriormente, o nivelamento do processo puxador pode e deve ser realizado trazendo os mesmos benefícios de uma implantação de nivelamento do processo puxador em um ambiente tradicional de produção enxuta.

Para realizar o nivelamento do processo puxador alguns conceitos como takt time, tempo de ciclo e processo puxador serão revistos adiante sob a ótica do ambiente ETO com alta variedade de produtos. Mais adiante, o método proposto será apresentado. 
O método proposto não inclui todas as ações preconizadas por Rother e Shook (1999), ou seja, o método parte de um momento onde a situação atual da empresa já foi mapeada e analisada e a situação futura já foi mapeada também.

\subsubsection{Definição do takt time para ambientes com alta variação de tempos de ciclo}

Em situações de extrema variação de tempos de ciclo, o conceito de takt time deve ser aplicado de maneira adaptada, de forma a atender às características específicas deste tipo de ambiente.

Primeiramente, o takt time não poderá ser calculado da maneira tradicional, pois, conforme discutido na Seção 2.2.8.1, quando há alta variação dos tempos de ciclo, não é possível garantir que a produção trabalhe no ritmo do takt time, já que há produtos com tempos de ciclo mais altos e produtos com tempos de ciclo mais baixos que o takt time.

A fim de transformar todos os tempos de ciclo em uma única base de forma a facilitar o entendimento e deixar clara a relação entre tempos de diferentes produtos, foi adotado o que foi denominado sistema de pontos, onde um ponto corresponde a um período de tempo (conforme utilizado por Tardin (2001) e apresentado na Seção 2.2.8.3). Para que seja entendido o conceito, será utilizada a relação de um ponto para um minuto. Ou seja, uma peça que possui um tempo de ciclo de 2 minutos representa 2 pontos.

Somente com essa normalização dos tempos de ciclo se torna possível adaptar o conceito de takt time a fim de utilizá-lo em um ambiente com alta variação de tempos de ciclo.

Com essa adaptação, o cálculo do takt time é feito conforme Equação 3:

Equação 3 - Cálculo do takt time utilizando o sistema de pontos

$$
\text { Takt time }=\frac{\text { Tempo disponível no período }}{\text { Total de pontos vendidos no período }}
$$

Nesse caso, o takt time calculado possui a unidade de minutos por ponto, por exemplo, 1,3 minutos por ponto. Para analisar esse número é preciso voltar à definição de 
ponto mostrada anteriormente que, para efeito de entendimento, um ponto representa um minuto.

Sendo assim, um takt time de 1,3 minutos por ponto representa que o processo deve produzir um ponto a cada 1,3 minutos e um ponto demora 1 minuto para ser produzido, o que resulta em um takt time dentro da capacidade do processo.

Caso o takt time calculado fosse menor do que 1 minuto por ponto, isso representaria um takt time abaixo da capacidade do processo, já que ele teria disponível um tempo menor do que 1 minuto para produzir uma peça que demora 1 minuto para ser produzida.

Com essa adaptação, foi possível utilizar o conceito de takt time para um ambiente ETO com alta variedade de produtos.

\subsubsection{Estimativa de tempo de ciclo do fluxo do puxador}

O conhecimento do tempo de ciclo é o primeiro passo para a definição dos pontos de um produto e para a implantação do nivelamento do processo puxador.

Por esse motivo, apesar de não haver dados históricos sobre tempos de ciclo dos produtos, deve-se chegar a esses valores nem que seja de uma forma estimada (conforme visto na Seção 2.2.8.4).

A estimativa de tempo de ciclo das peças varia de processo a processo e os passos para estimar o tempo de ciclo das peças de um processo são:

Passo 1: Observar o processo

A observação do processo é importante para entender como o processo funciona.

$\square$ Passo 2: Identificar as variáveis do produto que interferem no tempo de ciclo do processo

Através da observação, deve-se levantar possíveis características dos produtos que fazem com que o tempo de ciclo dos produtos varie (tanto para cima quanto para baixo). Características como peso, espessura, tipo de matéria-prima, comprimento, diâmetro, 
temperatura, entre outras, podem ser variáveis do produto que interfiram no tempo de ciclo do processo.

口 Passo 3: Identificar as variáveis do processo que fazem com que o tempo de ciclo se altere

Também através da observação devem-se identificar quais características do processo que podem interferir no tempo de ciclo como forma de manusear a peça e utilização de equipamento para movimentação das peças.

Passo 4: Criar um algoritmo para estimar o tempo de ciclo baseado nos passos anteriores

Com as observações realizadas é necessário fazer um estudo de tempos baseado no que foi apresentado na Seção 2.2.8.4 a fim de elaborar uma fórmula capaz de estimar o tempo de ciclo do processo.

Passo 5: Atualizar periodicamente ou sempre que houver alguma mudança de processo ou significativa de mix de produtos

O tempo de ciclo que deve ser utilizado para o nivelamento do processo puxador deve ser o tempo de ciclo do RRC, já que todos os processos do fluxo de valor devem trabalhar no ritmo do processo que limita a capacidade do fluxo (RRC).

\subsubsection{Situação de posicionamento do RRC no fluxo}

O posicionamento do RRC no fluxo de valor é importante para determinar como será realizado o nivelamento do processo puxador. A forma de programar e nivelar o processo puxador depende de dois fatores. O primeiro deles é o posicionamento do RRC em relação ao processo puxador e o segundo é a dedicação dos processos às famílias de produto da empresa.

A Figura 29 mostra quatro possibilidades de posicionamento do RRC no fluxo de valor: 


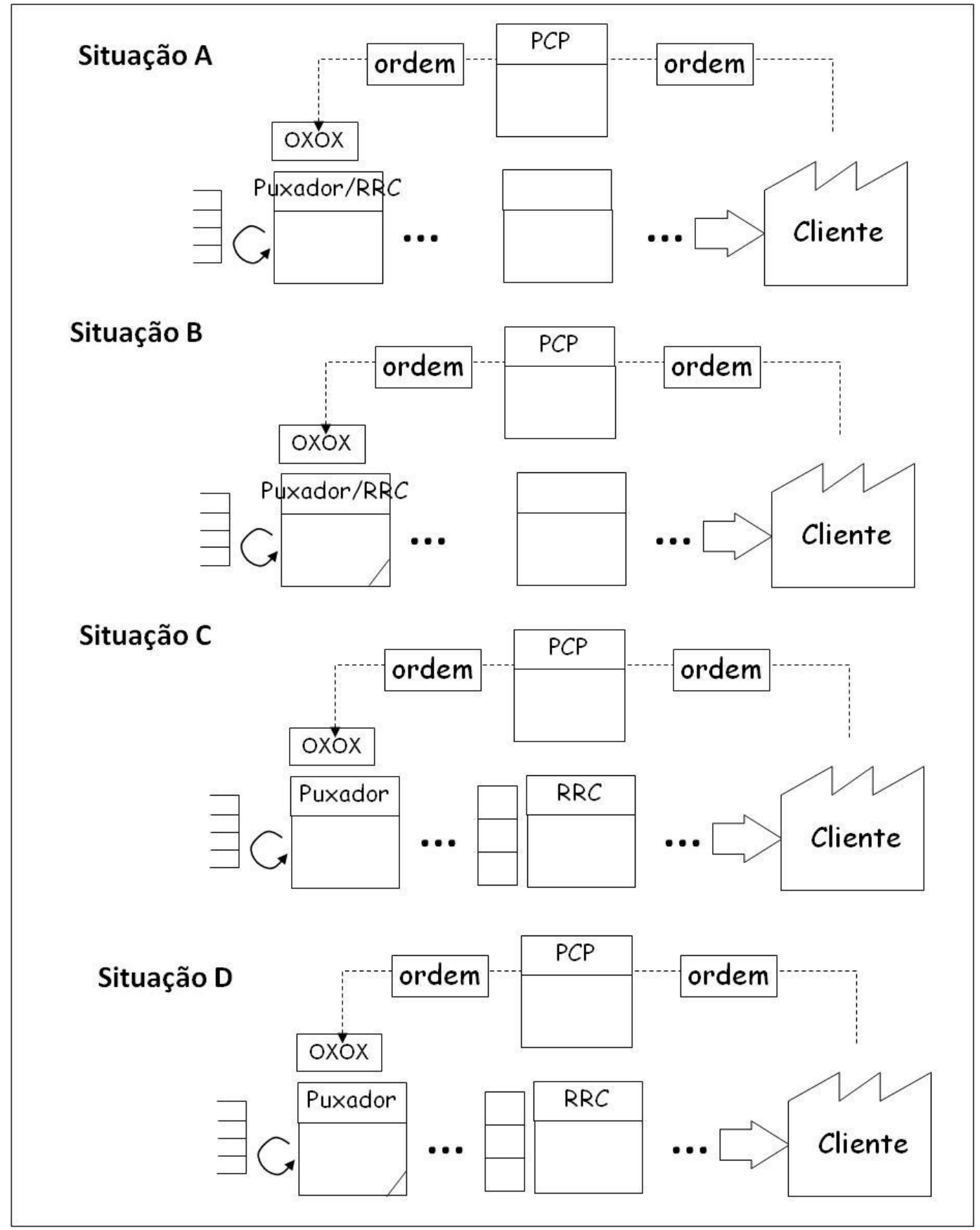

Figura 29 - Situações de posicionamento do RRC no fluxo de valor

\section{Situação A - O RRC como puxador e um processo dedicado}

A primeira possibilidade, apresentada na Situação A, acontece quando o processo puxador é o recurso restrição do fluxo (RRC) e é um processo dedicado a uma única família de produtos. Nesse caso, a programação do processo puxador considera a capacidade do 
próprio recurso, uma vez que esse é o recurso restrição do sistema e ele determina o ritmo de produção de todo o fluxo. Nessa situação, o processo puxador é um recurso dedicado a uma família de produtos, ou seja, só produz produtos de uma única família de produtos.

\section{Situação B - O RRC como puxador e um processo compartilhado}

A Situação B é caracterizada por um processo puxador que é o recurso restrição e é um processo compartilhado entre duas ou mais famílias de produto. Para essa situação, a programação do processo puxador considera a capacidade do próprio recurso, que é a restrição do fluxo. Uma característica importante dessa situação é definir a forma de priorização da programação das famílias de produtos no processo puxador.

O compartilhamento do processo puxador é identificado na Figura 29 pelo traço na diagonal no canto inferior direito do ícone de processo apresentado no Mapa de Fluxo de Valor.

Situação C - O RRC como parte do fluxo com um processo puxador distinto e dedicado

A terceira opção de posicionamento, apresentada na Situação C, acontece quando o RRC é um processo do fluxo do processo puxador, mas é um processo distinto do processo puxador. Nessa situação, tanto o processo puxador quanto o RRC são recursos dedicados a uma família de produtos.

\section{Situação D - O RRC como parte do fluxo com um processo puxador distinto e} não-dedicado

Por fim, a quarta opção de posicionamento, apresentada na Situação D, ocorre quando o processo puxador é compartilhado e é um processo distinto do RRC. Outra característica dessa situação é a dedicação do RRC a uma família de produtos. A diferença entre a Situação C e a Situação D está no fato do processo puxador ser um recurso compartilhado entre duas ou mais famílias de produto, ou seja, o processo puxador produz produtos que fazem parte de mais de uma família de produtos.

Outras possibilidades de posicionamento do RRC podem ocorrer, mas não serão tratadas neste trabalho, como RRC nos fluxos puxados anteriores ao processo puxador e outros processos compartilhados (inclusive o RRC) presentes no fluxo de valor do processo puxador. 
Cada uma das situações apresentadas anteriormente possui características que devem ser consideradas no momento de realizar a programação e nivelamento do processo puxador.

\subsubsection{Procedimento de Programação do Processo Puxador de acordo com o posicionamento do RRC}

Para cada uma das situações de posicionamento do RRC apresentadas anteriormente, há um procedimento específico para a realização da programação e nivelamento do processo puxador. Adiante serão mostrados os procedimentos para as quatro situações apresentadas.

\section{Procedimento de programação do processo puxador para a Situação A}

Para programar e nivelar o processo puxador em um fluxo de valor conforme a Situação A, onde o processo puxador é o RRC, o procedimento deve ser realizado de acordo com os seguintes passos:

Passo A.1: Estimar tempo de ciclo no RRC

O tempo de ciclo do processo puxador (ou do RRC, pois são o mesmo processo) deverá ser estimado conforme procedimento mostrado anteriormente.

Passo A.2: Definir takt time para o fluxo de valor

A definição do takt time deve ser feita de acordo com o cálculo apresentado na Seção 3.1.1.

Passo A.3: Definir capacidade programada do RRC

É importante que o processo trabalhe no ritmo definido pelo takt time e não, necessariamente, na sua capacidade máxima. Para isso, é preciso calcular a capacidade programada, que é representada pela quantidade necessária a ser produzida ao dia para atender a demanda dos clientes ao final de um período.

A capacidade programada é a quantidade que deverá ser produzida pelo RRC e, conseqüentemente, pelos outros processos do fluxo de valor diariamente. A quantidade que deverá ser programada é representada pela somatória de tempos de ciclo multiplicado pela 
demanda de todos os produtos que passam pelo processo puxador em relação ao tempo total disponível, conforme mostrado na Equação 4.

O valor encontrado na Equação 4 é um número adimensional, ou seja, não possui unidade. $\mathrm{O}$ valor deve ser interpretado como um percentual de utilização do tempo disponível no processo. Nesse caso, se o recurso for gargalo a capacidade programada deve preencher todo o tempo disponível do recurso. Caso não seja gargalo, a capacidade programada não ocupa todo o tempo disponível do recurso.

Equação 4 - Cálculo de capacidade programada

$$
\text { Capacidade programada }=\frac{\sum_{i=1}^{f}(\text { Tempo de Ciclo }) i *(\text { Demanda no período }) i}{\text { Tempo disponível no período }}
$$

口 Passo A.4: Programar até completar a capacidade programada

Com os tempos de ciclo estimados e convertidos em pontos, os produtos a serem programados devem ser inseridos, um a um, em um conjunto de peças programadas no RRC,

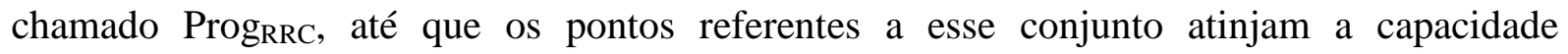
programada.

$\square$ Passo A.5: Formalizar no heijunka box

O último passo é fazer com que a programação definida na fase anterior seja formalizada no heijunka box, ou seja, os programadores deixem a informação sobre a programação disponível aos operadores de maneira visual utilizando o quadro de nivelamento de produção para isso.

A Figura 30 ilustra o procedimento de programação para a Situação A de acordo com os passos descritos anteriormente: 


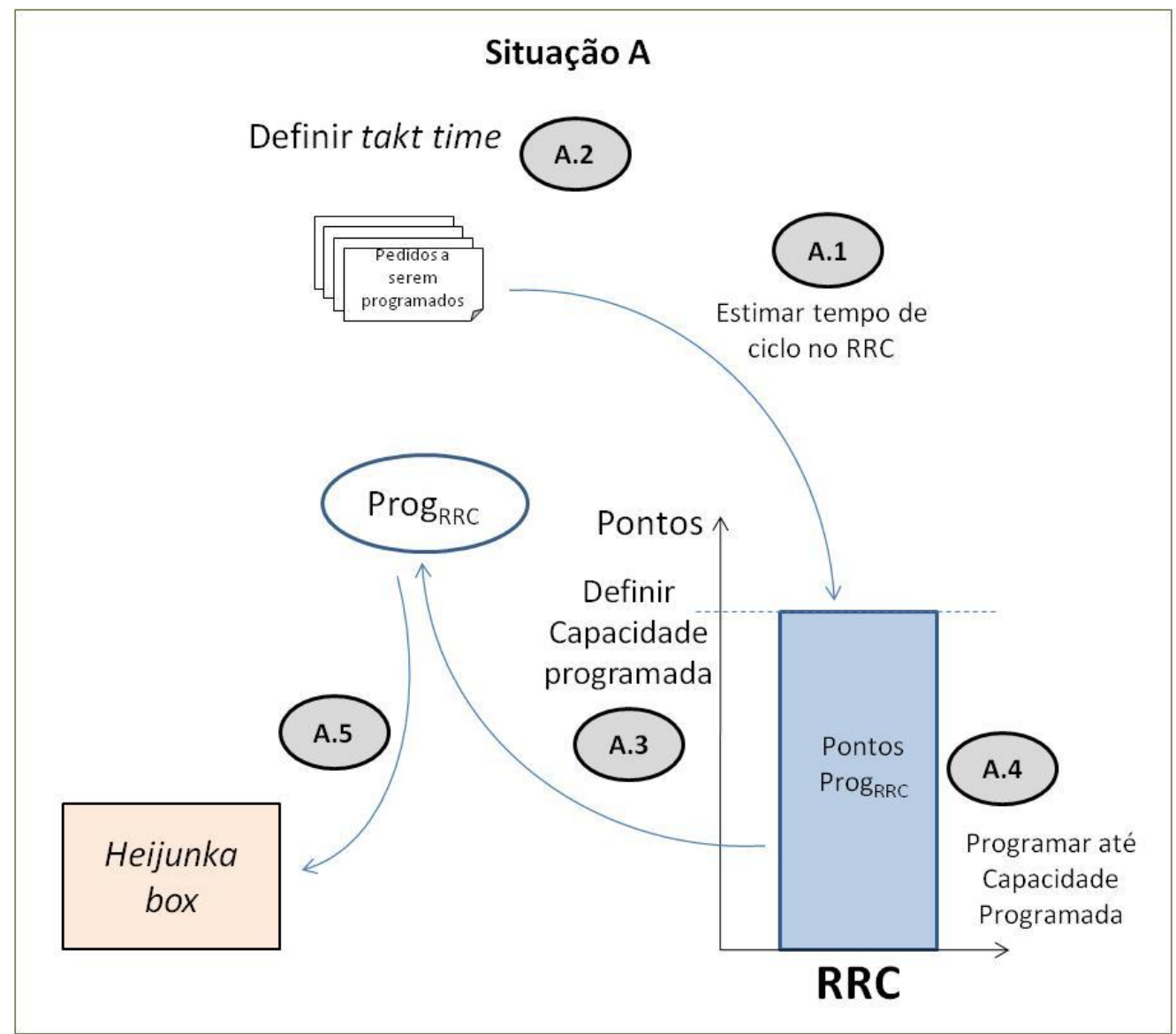

Figura 30 - Procedimento de programação e nivelamento do processo puxador para a Situação A

\section{Procedimento de programação do processo puxador para a Situação B}

A programação do processo puxador para a Situação B é bastante similar ao procedimento de programação para a Situação A. No entanto, para programar o processo puxador na Situação B, é necessário definir uma priorização das famílias de produtos, visto que o processo puxador é compartilhado entre duas ou mais famílias de produto.

Uma sugestão na forma de priorizar a programação é dividir a capacidade do RRC de acordo com a participação de cada família de produto, ou seja, uma família de produto com maior representatividade nas vendas possui uma parcela maior da capacidade do RRC para ser programada.

Entretanto, outras formas de priorização podem ser utilizadas de acordo com a estratégia da empresa. 
Dessa forma, o procedimento de programação e nivelamento do processo puxador para a Situação B é realizado conforme os seguintes passos:

口 Passo B.1: Estimar tempo de ciclo no RRC

A estimativa de tempo de ciclo ocorre de forma análoga às outras situações apresentadas.

口 Passo B.2: Definir takt time

O passo B.2 deve ser realizado como nas situações anteriores.

口 Passo B.3: Definir capacidade programada do RRC

Esse passo também ocorre de forma análoga ao passo A.3.

Passo B.4: Definir priorização entre as famílias de produto que compartilham o processo puxador

Como duas ou mais famílias compartilham o processo puxador, que também é o RRC, deve haver uma priorização entre elas, seja por representatividade de vendas ou qualquer outro critério definido pela empresa.

口 Passo B.5: Programar até completar a capacidade programada

De acordo com a priorização feita no passo B.4, as peças devem ser programadas no processo até atingir a capacidade programada. Deve-se iniciar a programação pela família de produto que foi priorizada e continuar a formar o conjunto $\operatorname{Prog}_{R R C}$ de acordo com a prioridade das famílias, até que se atinja a capacidade programada.

\section{口 Passo B.6: Formalizar no heijunka box}

Por fim, assim como nas outras situações, a programação realizada deve ser formalizada no heijunka box para que os operadores visualizem a programação que deve ser realizada.

A Figura 31 ilustra o procedimento de programação e nivelamento do processo puxador para a Situação B conforme descrito anteriormente. Nela, é mostrada a seqüência de passos necessária para realizar o procedimento. 


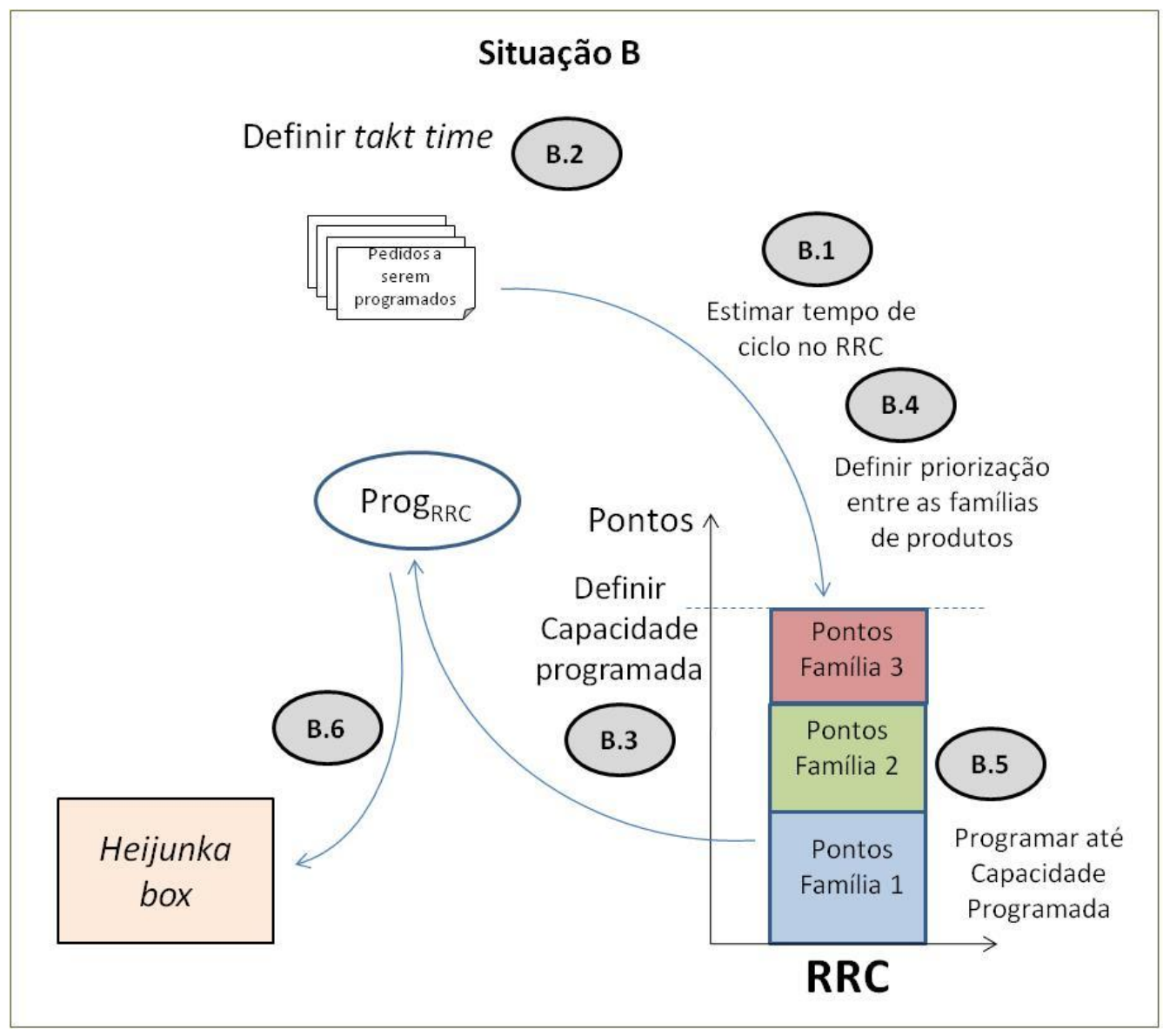

Figura 31 - Procedimento de programação e nivelamento do processo puxador para a Situação B

\section{Procedimento de programação do processo puxador para a Situação C}

O procedimento de programação e nivelamento do processo puxador para a situação C é bastante similar à situação A com a diferença de que o processo puxador é um processo distinto do RRC. A única ressalva é que a estimativa de tempo de ciclo deve ser feita para o RRC e o heijunka box deve estar posicionado no processo puxador.

Nessa situação, os processos anteriores ao RRC, por terem capacidade ociosa, trabalham o mais rápido possível para produzir toda a programação diária e depois cessam a produção até o próximo dia (para uma programação diária). Com essa ação, há formação de um buffer antes do RRC, que deve ser consumido durante o dia de produção. 
Após a conclusão da programação diária nos processos anteriores ao RRC, os operadores podem ser redirecionados para realizar outros tipos de atividades.

Sendo assim, os passos para a programação e nivelamento do processo puxador são:

Passo C.1: Estimar tempo de ciclo no RRC

Esse passo deve ser realizado de forma análoga às outras situações apresentadas.

口 Passo C.2: Definir takt time

O takt time deve ser calculado de forma análoga às situações anteriormente apresentadas.

口 Passo C.3: Definir capacidade programada do RRC

A capacidade programada deve ser calculada de forma análoga às situações anteriores.

口 Passo C.4: Programar até completar a capacidade programada

Os produtos devem ser alocados ao conjunto de peças programadas no RRC (Prog $\operatorname{RRC}_{\text {) }}$ até que se atinja a capacidade programada no RRC.

Passo C.5: Formalizar no heijunka box

A programação do processo puxador, representada pelo conjunto de peças Prog $_{\mathrm{PUX}}$, será formada pelo conjunto Prog $\operatorname{RRC}_{\text {R }}$. Nesse caso, os conjuntos $\operatorname{Prog}_{R R C}$ e Prog $\operatorname{PUX}_{\mathrm{P} X}$ são iguais, ou seja, formado pelas mesmas peças.

Essa programação deve ficar disponível ao chão de fábrica através do quadro de nivelamento da produção.

A Figura 32 ilustra o procedimento de programação e nivelamento do processo puxador para a Situação C de acordo com os passos descritos anteriormente. 


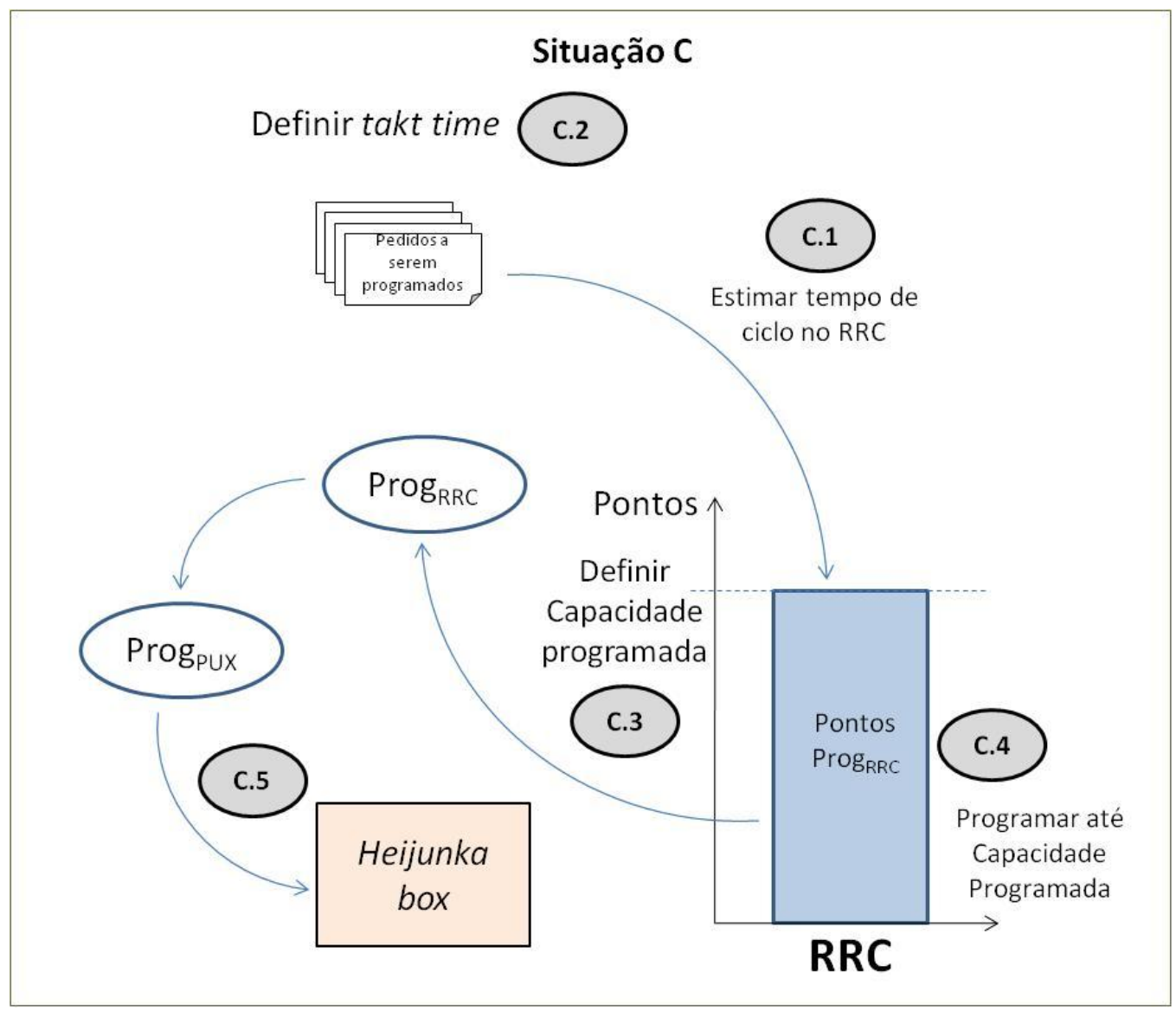

Figura 32 - Procedimento de programação e nivelamento do processo puxador para a Situação C

\section{Procedimento de programação do processo puxador para a Situação D}

A Situação D, representada pela distinção entre o processo puxador e o RRC com a característica do processo puxador ser um recurso compartilhado, tem o procedimento conforme descrito adiante.

Passo D.1: Estimar tempo de ciclo das peças para o RRC

A estimativa de tempos de ciclo das peças para o RRC é análoga à estimativa realizada nas situações anteriores.

口 Passo D.2: Definir takt time

O takt time deve ser definido conforme mostrado na Seção 3.1.1.

Passo D.3: Definir capacidade programada do RRC 
A definição da capacidade programada do RRC é realizada de maneira análoga à mesma etapa apresentada para as situações anteriores.

口 Passo D.4: Programar até completar a capacidade programada no RRC

A programação do RRC também deve ser realizada da mesma forma que foi realizada nas situações anteriormente apresentadas. As peças programadas nessa fase formarão o conjunto $\operatorname{Prog}_{\mathrm{R} R}$, representado pelas peças programadas no RRC.

Passo D.5: Estimar tempo de ciclo das peças para o processo puxador

Nesta etapa o tempo de ciclo das peças que passam pelo processo puxador deve ser estimado de forma análoga à estimativa realizada no RRC no passo D.1. Porém, os tempos de ciclo que devem ser estimados são referentes ao processo puxador.

- Passo D.6: Definir capacidade programada do processo puxador

Da mesma forma que a definição de capacidade foi feita para o RRC, ela também deve ser feita para o processo puxador.

A única diferença, para este caso, é que a demanda utilizada para a definição da capacidade programada do processo puxador deve ser a soma da demanda de todas as famílias de produtos que passam pelo processo puxador, considerando que, nesta situação, o processo puxador é um recurso compartilhado com duas ou mais famílias de produtos.

Passo D.7: Programar o processo puxador com as peças do Prog $\operatorname{RRC}_{\mathrm{R}}$

Nesta etapa deve ser estimado o tempo de ciclo das peças do conjunto $\operatorname{Prog}_{\text {RRC no }}$ processo puxador, que é um processo distinto do RRC para a Situação D.

口 Passo D.8: Programar até completar a capacidade programada no processo puxador

As peças de outras famílias de produto (que não passam pelo processo RRC) devem ter seu tempo de ciclo estimado e serem programadas no processo puxador até que a capacidade programada seja atingida, formando, assim, o conjunto Prog ${ }_{\mathrm{PUX}}$, formado pelas peças programadas no processo puxador.

口 Passo D.9: Formalizar no heijunka box 
Por fim, as informações sobre a programação do processo puxador devem ser disponibilizadas aos operadores de maneira visual através do quadro de nivelamento da produção.

A Figura 33, mostra o procedimento de nivelamento do processo puxador na Situação D de forma resumida. Nela, os passos definidos anteriormente estão identificados.

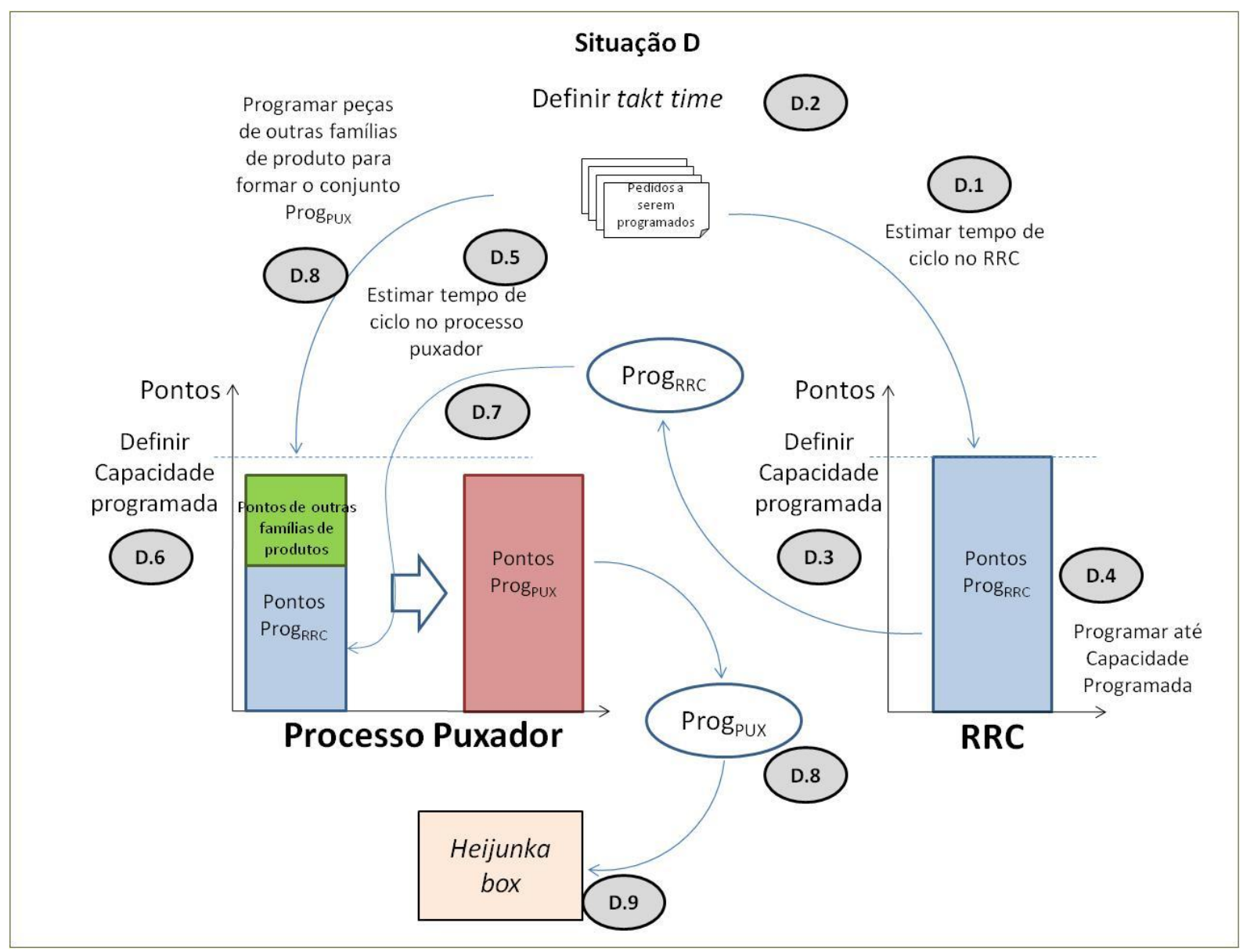

Figura 33 - Procedimento de programação e nivelamento do processo puxador para a

\section{Situação D}

Conforme pode ser observado, inicialmente, os tempos de ciclo das peças são estimados em pontos referentes ao RRC (passo D.1), o takt time é calculado (passo D.2) e as peças são programadas no RRC até o nível desejado (capacidade programada) (passos D.3 e D.4). 
O tempo de ciclo do processo puxador deve ser estimado para que seja feita a programação do processo puxador (passo D.5). Após preencher a capacidade programada do

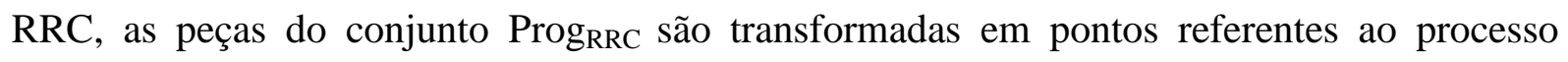
puxador (passo D.7). Como o processo puxador não é o RRC do fluxo, após processar as peças do conjunto $\operatorname{Prog}_{\mathrm{R} R C}$ ainda há capacidade ociosa, que deverá ser preenchida por peças de outras famílias de produtos. A programação do processo puxador é definida acrescentandose os pontos referentes às peças de outras famílias de produtos no processo puxador (passo D.8), até atingir o nível desejado, representado pela capacidade programada (passo D.6). As peças programadas no processo puxador formam o conjunto Prog $g_{\mathrm{PUX}}$ (passo D.8). Por fim, a programação do processo puxador deve ser disponibilizada aos operadores por meio do quadro de nivelamento da produção (passo D.9).

Neste capítulo foi apresentado o método proposto pela autora para programação e nivelamento do processo puxador em ambiente de alta variedade de produtos e estratégia de produção ETO para algumas situações de produção.

No Capítulo 4 será apresentada a aplicação onde foi implantado o modelo apresentado neste capítulo. 


\section{CAPÍTULO 4 - APLICAÇÃO DO MODELO DE PROGRAMAÇÃO NIVELADA DA}

\section{PRODUÇÃO}

Esse capítulo visa apresentar uma ilustração do modelo de programação e nivelamento do processo puxador através da descrição de uma aplicação.

Inicialmente será descrita brevemente a empresa que foi o cenário da implantação. Após a introdução sobre a empresa, são apresentadas as atividades realizadas durante a implantação.

Por fim, é apresentada a aplicação do modelo de programação da produção nivelada apresentado no Capítulo 3 na empresa estudada.

\subsection{Empresa}

A empresa objeto da aplicação possui uma única planta fabril localizada /no interior do estado de São Paulo e possui cerca de 200 funcionários. A empresa é uma das líderes do mercado brasileiro de vidros laminados para a construção civil.

A empresa buscou aplicar os conceitos de Produção Enxuta em sua manufatura há cerca de dois anos e, durante sua jornada, aplicou diversas ferramentas, como sistemas puxados, fluxo contínuo, TPM, SMED, entre outras. Dessa forma, conseguiu melhorar seu desempenho em relação a produtividade e pontualidade de entrega.

O trabalho realizado foi resultado de um projeto para implantação dos conceitos de Produção Enxuta com duração de aproximadamente dois anos e que envolveu, além de uma equipe de profissionais internos da empresa, uma equipe de consultoria na área. 
A aplicação apresentada refere-se a uma das implantações realizadas durante o projeto de implantação de conceitos de Produção Enxuta sobre a programação e nivelamento do processo puxador.

A equipe que trabalhou no projeto de implantação de conceitos de Produção foi formada por profissionais da empresa e de uma consultoria externa especializada em Produção Enxuta. A equipe de profissionais internos da empresa era formada por três pessoas, entre elas um patrocinador do projeto (gerente industrial) e duas pessoas dedicadas ao acompanhamento e execução do projeto. A equipe de consultoria era formada por um consultor sênior e outros três consultores, incluindo a autora deste trabalho.

Entre as famílias de produto que a empresa produz, podemos destacar algumas como vidros laminados, vidros insulados, vidros serigrafados e vidros temperados. A família de produto mais representativa para a empresa, com participação em cerca de $60 \%$ no faturamento, é a família de vidros laminados.

Os vidros laminados são compostos por duas ou mais lâminas de vidro, intercaladas com uma ou mais películas de PVB.

\subsection{Apresentação do caso}

Podemos considerar a tipologia de produção da empresa como ETO, ou seja, os pedidos dos clientes disparam o desenvolvimento ou alterações do projeto do produto, já que as dimensões dos vidros passadas pelos clientes são as mais variadas, não sendo possível determinar produtos padronizados, exceto por uma subfamília de vidros laminados chamada de chapas laminadas, vendidas a pequenos vidraceiros.

A principal família de produtos comercializados pela empresa são vidros laminados para construção civil. Na sua grande maioria, os pedidos são feitos pelos clientes no início da obra, porém, ainda não é possível iniciar a produção, pois a quantidade pedida é estimada. Próximo ao final da obra, após a conclusão da parte estrutural, os espaços que devem ser preenchidos por vidro são medidos e a necessidade de medidas é passada à empresa.

O processo de laminação de vidros, que é o recurso restrição da fábrica, consiste em unir duas placas de vidro, através de um filme plástico chamado PVB, em uma montagem 
manual e passar por um processo de calandragem a quente responsável por realizar a selagem completa das duas placas de vidro e eliminar bolhas de ar presentes entre as placas.

O processo de Laminação, antes do início do projeto de implantação dos conceitos de Produção Enxuta, era programado e controlado baseado em metros quadrados, ou seja, na soma das áreas dos vidros processados pelo processo de Laminação.

Porém, a programação e controle da produção utilizando a medida de metros quadrados não permitia uma visão clara de como o processo estava trabalhando, pois a área das peças não possuí relação com o tempo de ciclo das peças no processo.

Dessa forma, os programadores não sabiam dizer qual a capacidade do processo, pois esta dependia das peças produzidas, já que os tempos de ciclo eram bastante variados.

O mapa de fluxo de valor referente a situação antes das implantações para a família de vidros laminados é apresentado na Figura 34. Nele, é possível notar a seqüência de processos para essa família de produtos, que é primeiramente o processo de corte da lâmina de vidro, o segundo é o processo de laminação; após a laminação, o vidro para por um processo em uma autoclave, para finalizar a selagem dos vidros. O último processo é a lapidação, onde as bordas do vidro são lapidadas.

O MFV apresentado na Figura 34 mostra que as ordens de produção eram enviadas a todos os processos do fluxo e existiam estoques não dimensionados entre os processos. Apesar de não ser possível visualizar no MFV, o layout fabril prejudicava o transporte das peças, já que os equipamentos ficavam bastante distantes entre si e o caminho percorrido pelo produto era muito grande. 


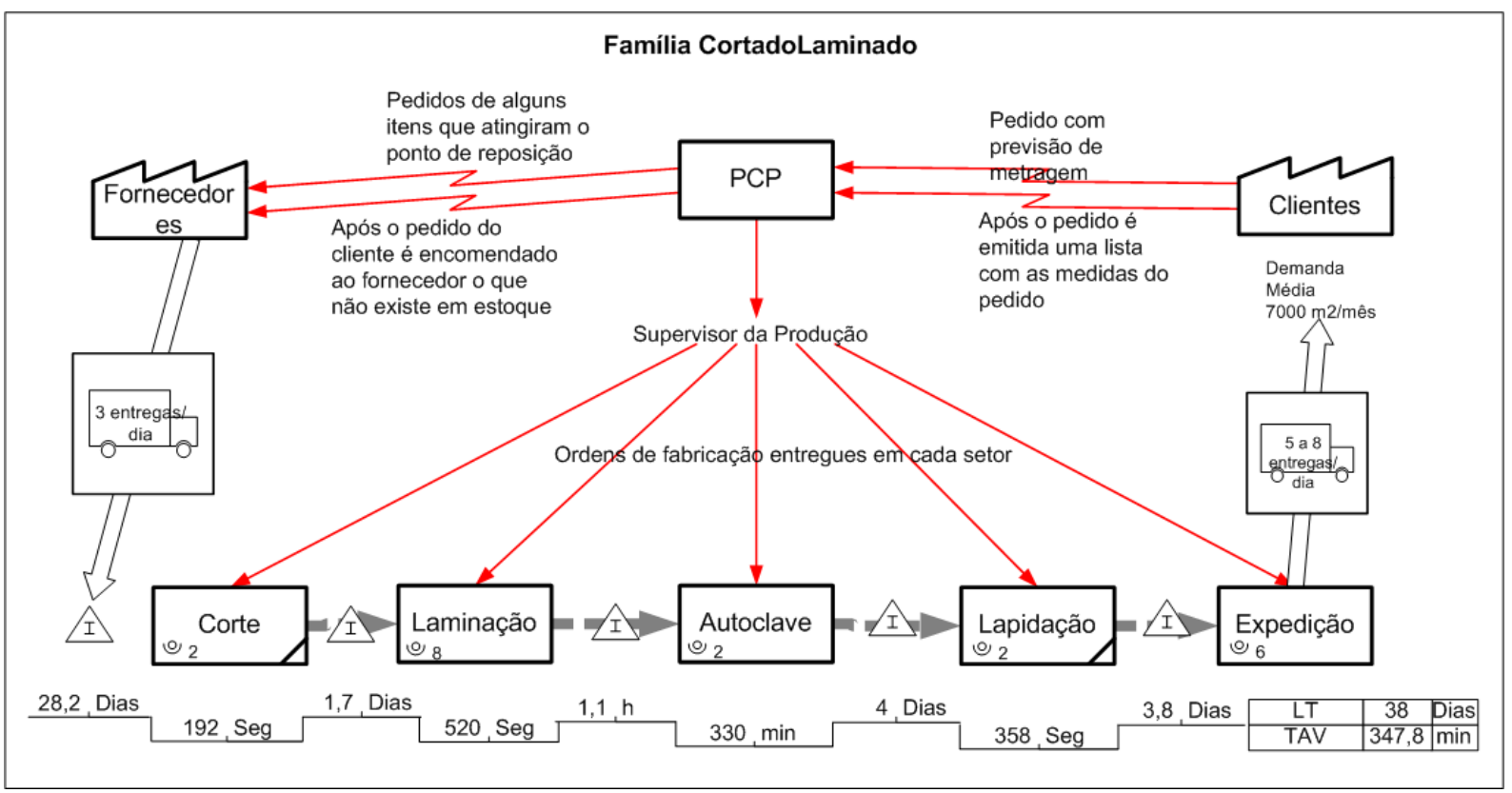

Figura 34 - Mapa de Fluxo de Valor para a situação anterior às implantações

Após o levantamento da situação antes das implantações e a análise dos problemas relacionados, foi desenhado o mapa de fluxo de valor da situação futura com as melhorias propostas, conforme apresentado na Figura 35.

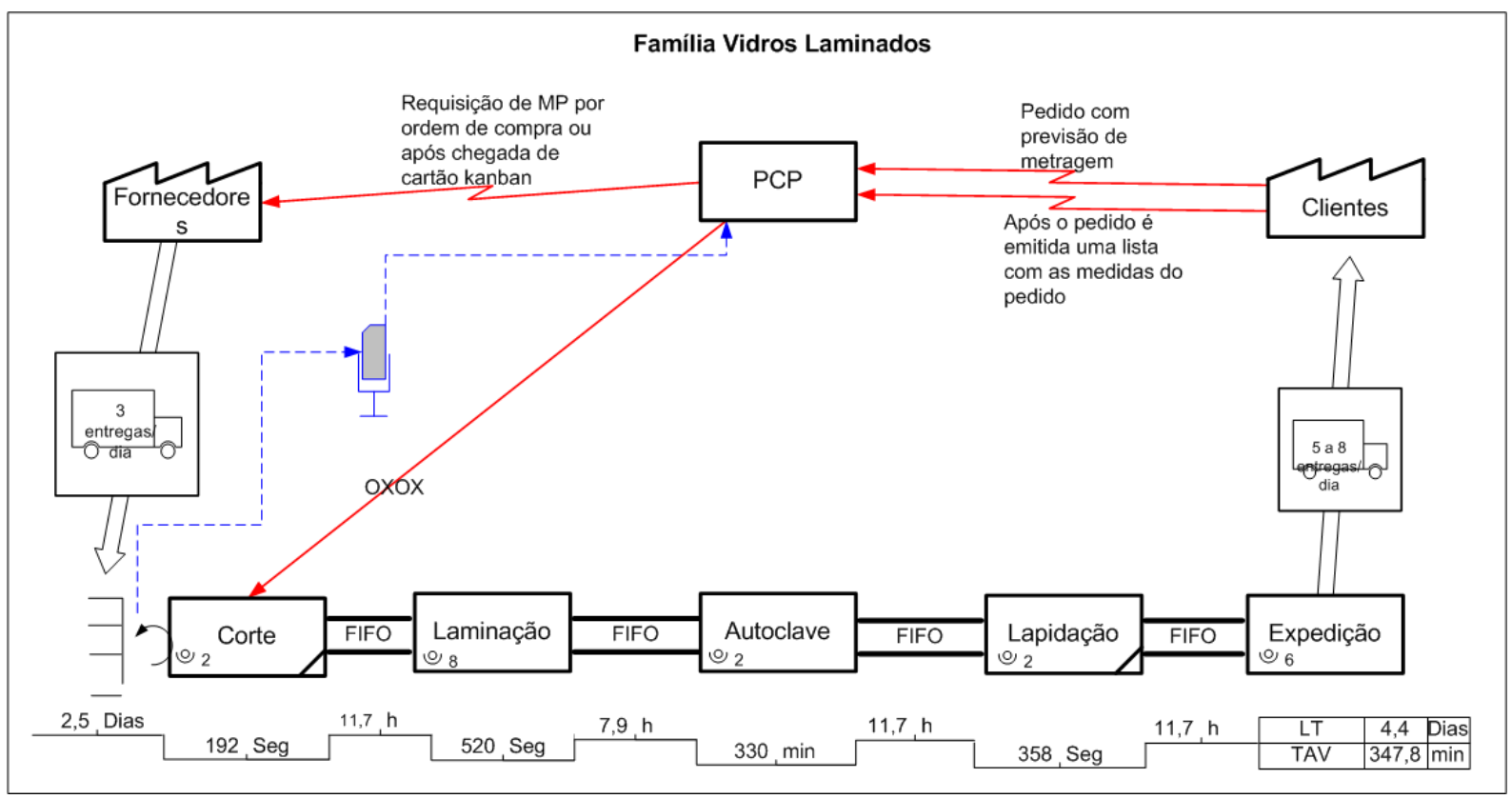

Figura 35 - Mapa de Fluxo de Valor referente à situação esperada após as implantações 
No MFV apresentado na Figura 35 é possível visualizar as melhorias propostas como supermercado de matéria-prima com o fornecedor, envio da programação somente para o processo puxador e linhas FIFO com tamanhos limitados.

Na situação futura apresentada na Figura 35 ainda há o envio de informações a todos os processos, porém isso só é necessário para informar as especificações do pedido para cada um dos processos e não como forma de programação da produção.

Analisando todo o fluxo de valor, a equipe percebeu que o recurso restrição era o processo de Laminação de vidros.

\subsection{Aplicação do Método}

O problema relevante para a apresentação desta aplicação é a situação de programação e nivelamento do processo puxador para a família de vidros laminados na empresa apresentada. A programação e o nivelamento do processo puxador foram realizados através do método apresentado no Capítulo 3.

O método apresentado neste trabalho foi aplicado na empresa estudada. Dentre as situações apresentadas na Seção 3.1.3, foi aplicada a Situação D, onde o processo puxador é distinto do RRC e o processo puxador é compartilhado com outras famílias de produto. Nesse caso, o Corte é o processo puxador, a Laminação é o RRC e outras famílias de produto compartilham o processo de Corte com a família de vidros laminados.

Adiante será apresentado passo a passo como foi aplicado o procedimento de programação e nivelamento do processo puxador para a situação apresentada.

\section{Aplicação do Passo D.1}

O Passo D.1 consiste em estimar o tempo de ciclo das peças do RRC em um ambiente ETO onde os tempos de ciclo são desconhecidos.

Para estimar o tempo de ciclo do processo de Laminação, que é o RRC do fluxo de valor, foi utilizado o procedimento mostrado na Seção 3.1.2. 
Inicialmente, foi realizada uma intensa observação do processo para entender a variação de tempo de ciclo entre diferentes produtos e identificar quais variáveis do produto causavam variação no tempo de ciclo.

As principais variáveis que alteram o tempo de ciclo identificadas no processo de Laminação foram:

- Largura e comprimento do vidro: vidros acima de determinado tamanho são manuseados através de um sistema de ventosas, enquanto que os demais vidros são transportados manualmente, por um ou dois operadores. A forma de manuseio implica em tempos de ciclo diferentes.

- Espessura do vidro: a velocidade de passagem do vidro pelo processo é diretamente proporcional a espessura do vidro laminado, ou seja, vidros mais espessos possuem um tempo de ciclo maior que vidros menos espessos.

- Vidro multilaminado: caso haja uma multilaminação de vidros o tempo de ciclo do produto será maior. Um vidro multilaminado é formado por três ou mais lâminas de vidro.

Apesar de, através das observações, ter sido possível identificar quais variáveis influenciam o tempo de ciclo e como elas influenciam o tempo de ciclo, não foi possível saber, ainda, quanto cada variável influencia.

O próximo passo para estimar o tempo de ciclo foi entender quanto cada variável apresentada anteriormente influenciava no tempo de ciclo dos produtos através da cronometragem de diversos produtos que envolvessem as diversas variáveis identificadas.

A cronometragem foi realizada em situações normais de produção, onde não havia paradas e havia operadores conforme o padrão de trabalho definido para o processo. A tomada de tempos foi realizada até se atingir dados confiáveis, porém não será discutida nesse trabalho a metodologia de tomada de tempos utilizada.

Foi realizada intensa observação com cronometragem dos produtos que passavam pelo processo de Laminação durante algumas semanas.

Com os dados coletados e analisados, foi definido um algoritmo que estimava o tempo de ciclo das peças. 
Para vidros multilaminados, somente o fato de o vidro ser multilaminado e a espessura do vidro influenciam no tempo de ciclo das peças, ou seja, nesse caso, a variável de largura e comprimento do vidro não influenciava no tempo de ciclo. A Tabela 6 mostra o tempo de ciclo estimado para vidros multilaminados de acordo com a espessura do vidro.

Tabela 6 - Estimativa de tempo de ciclo para vidros multilaminados

\begin{tabular}{|c|c|c|}
\hline \multicolumn{3}{|c|}{ Multi-laminado } \\
\cline { 1 - 2 } \multicolumn{2}{|c|}{ Espessura (mm) } & \multirow{2}{*}{ T/C (s) } \\
\cline { 1 - 2 } De & Até & 306 \\
\hline 6,0 & 20,9 & 360 \\
\hline 21,0 & 35,9 & 486 \\
\hline 36,0 & 50,9 & 828 \\
\hline 50,0 & 70,0 & \\
\hline
\end{tabular}

Para os outros vidros, exceto multilaminados, as variáveis de largura, comprimento e espessura do vidro influenciam na definição do tempo de ciclo. A largura e o comprimento do vidro determinam a forma de manusear a peça no processo, que pode ser classificada como: “1 Operador”, quando a peça é manuseada por somente um operador; "2 Operadores”, quando a peça deve ser manuseada por dois operadores; "2 Peças na Ventosa", quando a peça possui um tamanho que não pode ser manuseado por operadores e deve ser manuseado através de um sistema de ventosas e podem ser processadas duas peças por vez na ventosa; e "1 Peça na Ventosa" quando a peça só pode ser processada por sistema de ventosas e a ventosa processa apenas uma peça por vez.

A partir da definição de forma de manuseio das peças, a estimativa dos tempos de ciclo é mostrada na Tabela 7. É possível verificar que a espessura para as classificações "1 Operador" e "2 Operadores" não influencia o tempo de ciclo, visto que qualquer peça, independente de sua espessura, possui o mesmo tempo de ciclo estimado. 
Tabela 7 - Estimativa de tempo de ciclo para vidros laminados

\begin{tabular}{|c|c|c|c|c|c|}
\hline \multicolumn{6}{|c|}{ Vidros Laminados (exceto multilaminados) } \\
\hline \multicolumn{2}{|c|}{ Espessura (mm) } & 1 Operador & $\begin{array}{c}2 \\
\text { Operadores }\end{array}$ & $\begin{array}{l}2 \text { Peças na } \\
\text { Ventosa }\end{array}$ & $\begin{array}{l}1 \text { Peça na } \\
\text { Ventosa }\end{array}$ \\
\hline De & Até & $T / C(s)$ & $\mathrm{T} / \mathrm{C}(\mathrm{s})$ & $\mathrm{T} / \mathrm{C}(\mathrm{s})$ & $\mathrm{T} / \mathrm{C}(\mathrm{s})$ \\
\hline 6 & 7,9 & \multirow{7}{*}{24} & \multirow{7}{*}{42} & 102 & 117 \\
\hline 8 & 9,9 & & & 105 & 120 \\
\hline 10 & 11,9 & & & 108 & 129 \\
\hline 12 & 13,9 & & & 126 & 144 \\
\hline 14 & 15,9 & & & 144 & 165 \\
\hline 16 & 19,9 & & & 153 & 177 \\
\hline 20 & mais & & & 240 & 276 \\
\hline
\end{tabular}

A fim de utilizar uma linguagem mais fácil de ser compreendida pelos operadores sobre a relação entre tempos de ciclo de diferentes produtos, utilizou-se o conceito de pontos (conforme utilizado por Tardin (2001) e apresentado na Seção 2.2.8.3).

Cada ponto se refere a um período de tempo e, para a aplicação apresentada, definiuse que um ponto seria equivalente a um minuto. Por exemplo, um produto que vale 2 pontos significa que possui um tempo de ciclo estimado de aproximadamente 2 minutos.

Para isso, ao final do processo de estimativa do tempo de ciclo, os tempos de ciclo encontrados foram transformados em pontos por tipo de peças conforme as Tabela 8 e Tabela 9.

Tabela 8 - Estimativa em pontos dos tempos de ciclo para vidros multilaminados

\begin{tabular}{|c|c|c|}
\hline \multicolumn{3}{|c|}{ Multi-laminado } \\
\hline \multicolumn{2}{|c|}{ Espessura $(\mathbf{m m})$} & \multirow{2}{*}{ Pontuação } \\
\hline De & Até & \\
\hline 6,0 & 20,9 & 2,0 \\
\hline 21,0 & 35,9 & 2,2 \\
\hline 36,0 & 50,9 & 2,4 \\
\hline 50,0 & 70,0 & 2,8 \\
\hline
\end{tabular}


Tabela 9 - Estimativa em pontos dos tempos de ciclo para vidros laminados

\begin{tabular}{|c|c|c|c|c|c|}
\hline \multicolumn{6}{|c|}{ Vidros Laminados (exceto multilaminados) } \\
\hline \multicolumn{2}{|c|}{ Espessura (mm) } & 1 Operador & $\begin{array}{c}2 \\
\text { Operadores }\end{array}$ & $\begin{array}{l}2 \text { Peças na } \\
\text { Ventosa }\end{array}$ & $\begin{array}{l}1 \text { Peça na } \\
\text { Ventosa }\end{array}$ \\
\hline $\mathrm{De}$ & Até & Pontuação & Pontuação & Pontuação & Pontuação \\
\hline 6 & 7,9 & \multirow{7}{*}{0,4} & \multirow{7}{*}{0,7} & 1,7 & 2,0 \\
\hline 8 & 9,9 & & & 1,8 & 2,0 \\
\hline 10 & 11,9 & & & 1,8 & 2,2 \\
\hline 12 & 13,9 & & & 2,1 & 2,4 \\
\hline 14 & 15,9 & & & 2,4 & 2,8 \\
\hline 16 & 19,9 & & & 2,6 & 3,0 \\
\hline 20 & mais & & & 4,0 & 4,6 \\
\hline
\end{tabular}

Com essas informações para estimativa do tempo de ciclo definidas, foi criada uma planilha que analisa os dados sobre os produtos e apresenta o tempo de ciclo estimado para a peça. Na Tabela 10 é mostrada a planilha de estimativa de tempos de ciclo na qual são colocadas as informações sobre o produto (como espessura, quantidade de peças, largura, altura e se é um produto multilaminado) e a planilha retorna a pontuação do lote de peças.

Tabela 10 - Planilha de estimativa de tempos de ciclo para vidros laminados

\begin{tabular}{|c|c|c|c|c|c|c|c|c|}
\hline $\begin{array}{c}\text { Espessura } \\
(\mathbf{m m})\end{array}$ & Quantidade & $\begin{array}{c}\text { Largura } \\
(\mathbf{m m})\end{array}$ & $\begin{array}{c}\text { Altura } \\
(\mathbf{m m})\end{array}$ & $\begin{array}{c}\text { Área } \\
(\mathbf{m} 2)\end{array}$ & $\begin{array}{c}\text { Lado Menor } \\
(\mathbf{m m})\end{array}$ & $\begin{array}{c}\text { Lado Maior } \\
(\mathbf{m m})\end{array}$ & Classificação & Pontuação \\
\hline 10 & 260 & 1238 & 1512 & 486,7 & 1238 & 1512 & Ventosa 2 & $\mathbf{4 6 8 , 0}$ \\
\hline 6 & 260 & 1238 & 1512 & 486,7 & 1238 & 1512 & Ventosa 2 & $\mathbf{4 4 2 , 0}$ \\
\hline 12 & 26 & 1238 & 2986 & 96,1 & 1238 & 2986 & Ventosa 1 & $\mathbf{6 2 , 4}$ \\
\hline 10 & 78 & 1238 & 1586 & 153,2 & 1238 & 1586 & Ventosa 2 & $\mathbf{1 4 0 , 4}$ \\
\hline 10 & 26 & 1238 & 1336 & 43,0 & 1238 & 1336 & Multi-Laminado & $\mathbf{1 3 2 , 6}$ \\
\hline 8 & 100 & 1000 & 900 & 90,0 & 900 & 1000 & 1 Pessoa & $\mathbf{4 0 , 0}$ \\
\hline
\end{tabular}

A freqüência de execução do passo D.1 foi definido de acordo com a necessidade de atualização da pontuação referente a cada peça. Essa necessidade pode surgir quando houver mudança no número de operadores do processo, padronização de atividades, mudança de equipamentos ou qualquer outra ação que implique em alterações nos tempos de ciclo das peças. 


\section{Aplicação do Passo D.2}

O Passo D. 2 consiste em definir o takt time de acordo com as adaptações propostas a ambientes de alta variedade.

$\mathrm{Na}$ aplicação apresentada, a demanda utilizada para cálculo do takt time foi o histórico de vendas mensal dos últimos meses para a família de vidros laminados cujo valor é $23050 \mathrm{~m}^{2}$.

Apesar de mês a mês o mix de peças variarem bastante, verificou-se que o total de pontos vendidos não apresentava uma alta variação. Dessa forma, o conceito de takt time foi calculado utilizando o total de pontos vendidos mensalmente, a partir de um histórico de vendas dos últimos meses e ajustes de previsão realizados pela equipe Comercial.

A partir da estimativa de tempos de ciclo para o processo de Laminação, a demanda transformada de área para pontos representou o valor de 19350 pontos.

Com o histórico de área de vidros laminados vendida e da quantidade em pontos de vidros laminados vendidos nos últimos meses, obtida a partir da estimativa de tempo de ciclo para a Laminação, foi possível obter um valor médio de pontos por área de vidro laminado vendido, conforme a Equação 5:

Equação 5 - Pontuação média por área para o processo de Laminação

$$
\begin{gathered}
\text { Pontuação média por área }=\frac{\sum \text { pontos de vidros laminados vendido }}{\sum \text { área de vidros laminados vendida }}=\frac{19350 \text { pontos }}{23050 \mathrm{~m}^{2}} \\
=0,84 \frac{\text { pontos }}{\mathrm{m}^{2}}
\end{gathered}
$$

Com essas informações e o tempo disponível no processo de laminação foi possível definir o takt time conforme a Equação 6. Nela, foi considerada uma previsão de vendas em área dos vidros para os próximos meses de $23400 \mathrm{~m}^{2}$ e uma eficiência do processo de Laminação de $80 \%$. 
Equação 6 - Definição do takt time para o processo de Laminação

Takt time $=\frac{23 \text { dias } * 3 \text { turnos } * 7,5 \text { horas } * 3600 \frac{\text { segundos }}{\text { hora }} * 80 \%}{23400 m^{2} * 0,84 \text { pontos } / \mathrm{m}^{2}}=75,9 \frac{\text { segundos }}{\text { ponto }}$

O tempo disponível considerado na Equação 6 foi o tempo disponível mensal representado pela multiplicação entre 23 dias úteis no mês, 3 turnos de trabalho por dia útil, 7,5 horas de trabalho por turno (desconsiderando paradas programadas), 3600 segundos por hora e eficiência do processo de 80\%. A demanda em pontos utilizada na Equação 6 foi dada pela multiplicação entre a previsão de $23400 \mathrm{~m}^{2}$ feita pelo Comercial e pela relação de 0,84 pontos $/ \mathrm{m}^{2}$, encontrada a partir de dados históricos, totalizando uma previsão de demanda de 19656 pontos.

O takt time de 75,9 segundos por ponto definido na Equação 6 pode ser interpretado como se o processo de Laminação devesse produzir a cada 75,9 segundos um ponto, ou seja, uma ou mais peças cujos tempos de ciclo somados fossem de 60 segundos.

Nesse caso, pode-se afirmar que o processo de Laminação consegue atender a demanda, já que o takt time encontrado é superior ao tempo correspondente a um ponto.

A freqüência de execução desse passo deve ser de acordo com a previsão de demanda para um próximo período. Na aplicação a freqüência de atualização foi mensal, já que o departamento Comercial fornece mensalmente uma previsão de demanda para o próximo período.

\section{Aplicação do Passo D.3}

O passo D.3 consiste em definir a capacidade programada no processo de Laminação.

A capacidade programada no processo de Laminação deve ser a quantidade em pontos que deve ser produzida diariamente a fim de atender à demanda ao final do mês. Para 
calcular a capacidade programada, foi utilizada a Equação 4, conforme apresentado na Equação 7:

Equação 7 - Cálculo da capacidade programada para o processo de Laminação

$$
\begin{gathered}
\text { Capacidade programada }=\frac{60 \frac{\text { seg }}{\text { ponto }} * 19656 \text { pontos }}{23 \text { dias } * 3 \frac{\text { turnos }}{\text { dia }} * 7,5 \frac{\text { horas }}{\text { turno }} * 3600 \frac{\text { segundos }}{\text { hora }} * 80 \%} \\
\quad=0,79=356,1 \frac{\text { pontos }}{\text { turno }}
\end{gathered}
$$

O tempo de ciclo utilizado na Equação 7 é de 60 segundos por ponto pois é o tempo necessário para produzir um ponto no processo.

O tempo disponível utilizado na Equação 7 foi o mesmo utilizado para o cálculo do takt time.

O valor de 0,79 encontrado para a Equação 7 representa que $79 \%$ da capacidade total do processo deve ser programada. Nesse caso, a capacidade total é de 450 pontos por turno e $79 \%$ da capacidade total representa uma necessidade de programação de 356,1 pontos por turno.

A freqüência de realização desse passo é análoga à freqüência do passo anterior. Nesse caso, a execução desse passo acontece com freqüência mensal.

\section{Aplicação do Passo D.4}

Com a capacidade programada definida, o próximo passo é seqüenciar todos os pedidos de vidros laminados de acordo com o critério de data de entrega prometida ao cliente. A estimativa de tempo de ciclo deve ser aplicada para cada um dos produtos que fazem parte dos pedidos. Os produtos que devem ser programados vão sendo selecionados até que se atinja a capacidade programada no processo. 
A Figura 36 mostra parte da planilha utilizada para operacionalizar a programação e nivelamento do processo de Corte. Nela, é possível visualizar, na parte inferior, as peças dos pedidos e suas principais informações, inclusive a pontuação do lote. Na parte superior, à direita, é possível visualizar um resumo da programação já realizada para o processo de Laminação. Na visualização, é possível acompanhar a programação em dois dias (10/05/2010 e 11/05/2010), a respectiva pontuação acumulada no dia e o percentual que essa pontuação representa em relação à capacidade programada. A capacidade programada listada foi obtida através do resultado da Equação 7 e multiplicada pelo total de turnos trabalhados por dia.

Ainda conforme a Figura 36, é possível visualizar que os pedidos foram sendo alocados ao dia 10/05/2010 até que a capacidade programada para este dia fosse completada. Nesse caso, foi considerada completa a capacidade programada caso houvesse uma variação, para mais ou para menos, de 5\%, ou seja, caso o percentual da pontuação do $\operatorname{Prog}_{\mathrm{RRC}}$ em relação à capacidade programada variasse de $95 \%$ a 105\%. No dia 11/05/2010, a capacidade programada ainda não foi completada, com apenas cerca de $46 \%$ da capacidade programada preenchida. Para o dia 11/05/2010, os próximos pedidos na lista de prioridades devem ser alocados para esta data até que a capacidade programada seja atingida.

\begin{tabular}{|c|c|c|c|c|c|c|c|c|c|}
\hline & & & & & & & \multicolumn{3}{|c|}{ LAMINAÇÃO } \\
\hline & & & & & & & Data & Pontuação & \% Total \\
\hline & & & & & & & $10 / 05 / 2010$ & 1058,2 & $99,2 \%$ \\
\hline & & & & & & & $11 / 05 / 2010$ & 495,6 & $46,4 \%$ \\
\hline & & & & & & & $\begin{array}{c}\text { Capacidade } \\
\text { programada } \\
\text { (por dia) }\end{array}$ & 1067,2 & \\
\hline & & & & & & & $\begin{array}{c}\text { Takt time } \\
\text { (seg/ponto) }\end{array}$ & 75,9 & \\
\hline & & & & & & & Turnos/Dia & 3 & \\
\hline & & & & & & & Eficiência & $80 \%$ & \\
\hline Pedido & Família & $\begin{array}{l}\text { Quantidade } \\
\text { de peças }\end{array}$ & $\begin{array}{c}\text { Largura } \\
(\mathrm{mm})\end{array}$ & $\begin{array}{l}\text { Altura } \\
(\mathrm{mm})\end{array}$ & $\begin{array}{c}\text { Espessura } \\
(\mathrm{mm})\end{array}$ & $\begin{array}{c}\text { Data de } \\
\text { processamento }\end{array}$ & & ontuação & \\
\hline 223476 & Laminado & 130 & 1238 & 1512 & 10 & $10 / 05 / 10$ & & 468,00 & \\
\hline 226453 & Laminado & 124 & 1238 & 1582 & 8 & 10/05/10 & & 421,60 & \\
\hline 227443 & Laminado & 26 & 1238 & 1336 & 10 & $10 / 05 / 10$ & & 132,60 & \\
\hline 227443 & Laminado & 90 & 1000 & 900 & 8 & $10 / 05 / 10$ & & 36,00 & \\
\hline 227443 & Laminado & 68 & 675 & 1221 & 8 & $11 / 05 / 10$ & & 47,60 & \\
\hline 228765 & Laminado & 26 & 1238 & 2986 & 12 & $11 / 05 / 10$ & & 62,40 & \\
\hline 228659 & Laminado & 78 & 1238 & 1586 & 10 & $11 / 05 / 10$ & & 140,40 & \\
\hline 224560 & Laminado & 130 & 500 & 720 & 6 & $11 / 05 / 10$ & & 52,00 & \\
\hline 225553 & Laminado & 92 & 1022 & 1450 & 12 & $11 / 05 / 10$ & & 193,20 & \\
\hline
\end{tabular}

Figura 36 - Programação do processo de Laminação

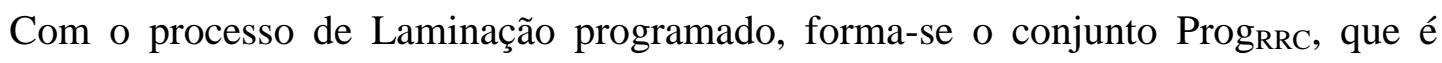
formado por todas as peças programadas na Laminação durante um dia de produção. 
O passo D.4 acontece com freqüência diária, já que a programação da produção é enviada diariamente para a fábrica.

\section{Aplicação do Passo D.5}

Não será detalhado neste trabalho o processo de estimativa de tempo de ciclo do Corte, visto que foi realizado de forma análoga ao processo de estimativa de tempo de ciclo da Laminação, porém considerando as variáveis dos produtos e dos processos relativas ao processo de Corte.

A freqüência de execução do passo D.5 é análoga à freqüência de execução do passo D.1.

\section{Aplicação do Passo D.6}

Após a estimativa de tempo de ciclo do Corte estar concluída, a capacidade programada do Corte deve ser definida. Para isso, foi calculado o takt time para o processo de Corte da mesma forma que foi feito com o processo de Laminação.

Primeiramente, a pontuação média por área do vidro para o processo de Corte foi calculada, conforme mostrado na

Equação 8:

Equação 8 - Pontuação média por área para o processo de Corte

$$
\text { Pontuação média por área }=\frac{16105 \text { pontos }}{38200 \mathrm{~m}^{2}}=0,42 \frac{\text { pontos }}{\mathrm{m}^{2}}
$$

O takt time calculado para o processo de Corte é apresentado na

Equação 9: 
Equação 9 - Definição do takt time para o processo de Corte

Takt time $=\frac{23 \text { dias } * 3 \text { turnos } * 7,5 \text { horas } * 3600 \frac{\text { seg }}{\text { hora }} * 70 \%}{38500 \mathrm{~m} 2 * 0,42 \text { pontos } / \mathrm{m} 2}=80,3 \frac{\text { segundos }}{\text { ponto }}$

A capacidade programada também foi calculada de forma análoga ao cálculo feito para o processo de Laminação. O cálculo da capacidade programada para o processo de Corte é apresentado na Equação 10:

Equação 10 - Cálculo da capacidade programada para o processo de Corte

$$
\begin{gathered}
\text { Capacidade programada }=\frac{60 \frac{\text { seg }}{\text { ponto }} * 16170 \text { pontos }}{23 \text { dias } * 3 \frac{\text { turnos }}{\text { dia }} * 7,5 \frac{\text { horas }}{\text { turno }} * 3600 \frac{\text { segundos }}{\text { hora }} * 70 \%} \\
\quad=0,74=334,8 \frac{\text { pontos }}{\text { turno }}
\end{gathered}
$$

A freqüência de execução do passo D.6 é análoga à freqüência de execução do passo D.3.

\section{Aplicação do Passo D.7}

Na Figura 37, pode-se visualizar a quantidade em pontos que o conjunto Prog $\operatorname{RRC}$ possui no processo de Corte. Na parte superior, a direita, é possível visualizar a quantidade programada para os processos de Corte e Laminação e a programação em pontos para dois dias de produção. É possível visualizar também a capacidade programada definida para o Corte, além do número de turnos trabalhados ao dia e eficiência do processo. 


\begin{tabular}{|c|c|c|c|c|c|c|c|c|c|c|c|c|}
\hline & & & & & & & \multicolumn{3}{|c|}{ CORTE } & \multicolumn{3}{|c|}{ LAMINAÇÃO } \\
\hline & & & & & & & Data & Pontuação & $\%$ Total & Data & Pontuação & \% Total \\
\hline & & & & & & & $10 / 05 / 2010$ & 468,7 & $46,5 \%$ & $10 / 05 / 2010$ & 1058,2 & $99,2 \%$ \\
\hline & & & & & & & $11 / 05 / 2010$ & 270,3 & $26,8 \%$ & $11 / 05 / 2010$ & 495,6 & $46,4 \%$ \\
\hline & & & & & & & $\begin{array}{c}\text { Capacidade } \\
\text { programada } \\
\text { (por dia) }\end{array}$ & 1008,7 & & $\begin{array}{c}\text { Capacidade } \\
\text { programada } \\
\text { (por dia) }\end{array}$ & 1067,2 & \\
\hline & & & & & & & $\begin{array}{c}\text { Takt time } \\
\text { (seg/ponto) }\end{array}$ & 80,3 & & $\begin{array}{c}\text { Takt time } \\
\text { (seg/ponto) }\end{array}$ & 75,9 & \\
\hline & & & & & & & Turnos/Dia & 3 & & Turnos/Dia & 3 & \\
\hline & & & & & & & Eficiência & $70 \%$ & & Eficiência & $80 \%$ & \\
\hline Pedido & Família & $\begin{array}{c}\text { Quantidade } \\
\text { de peças }\end{array}$ & $\begin{array}{c}\text { Largura } \\
(\mathrm{mm})\end{array}$ & $\begin{array}{l}\text { Altura } \\
(\mathrm{mm})\end{array}$ & $\begin{array}{c}\text { Espessura } \\
(\mathrm{mm})\end{array}$ & $\begin{array}{c}\text { Data de } \\
\text { processamento }\end{array}$ & & Pontuação & & & Pontuação & \\
\hline 223476 & Laminado & 130 & 1238 & 1512 & 10 & $10 / 05 / 10$ & & 187,40 & & & 468,00 & \\
\hline 226453 & Laminado & 124 & 1238 & 1582 & 8 & $10 / 05 / 10$ & & 188,78 & & & 421,60 & \\
\hline 227443 & Laminado & 26 & 1238 & 1336 & 10 & $10 / 05 / 10$ & & 24,97 & & & 132,60 & \\
\hline 227443 & Laminado & 90 & 1000 & 900 & 8 & $10 / 05 / 10$ & & 67,50 & & & 36,00 & \\
\hline 227443 & Laminado & 68 & 675 & 1221 & 8 & $11 / 05 / 10$ & & 22,10 & & & 47,60 & \\
\hline 228765 & Laminado & 26 & 1238 & 2986 & 12 & $11 / 05 / 10$ & & 39,00 & & & 62,40 & \\
\hline 228659 & Laminado & 78 & 1238 & 1586 & 10 & $11 / 05 / 10$ & & 91,63 & & & 140,40 & \\
\hline 224560 & Laminado & 130 & 500 & 720 & 6 & $11 / 05 / 10$ & & 65,00 & & & 52,00 & \\
\hline 225553 & Laminado & 92 & 1022 & 1450 & 12 & $11 / 05 / 10$ & & 52,61 & & & 193,20 & \\
\hline
\end{tabular}

Figura 37 - Programação parcial do Corte com as peças do conjunto Prog $\operatorname{RRC}$

É possível observar que o $\operatorname{Prog}_{\mathrm{RRC}}$ não ocupa toda a capacidade programada do Corte. Há ainda uma parcela significativa do Corte disponível para programar peças de outras famílias de produtos.

O passo D.7 é aplicado com freqüência diária.

\section{Aplicação do Passo D.8}

A seguir, com a capacidade programada do Corte calculada, o objetivo é preencher a programação do Corte com peças de famílias de produto diferentes dos vidros laminados.

A Figura 38 mostra a lista de pedidos da família de vidros laminados e de outras famílias que constam na programação de um dia de produção e a pontuação referente a eles nos processos de Corte e Laminação.

É possível verificar que os últimos pedidos listados não possuem pontuação no processo de Laminação. Isso significa que são os pedidos das outras famílias de produtos que não passam pelo processo de Laminação. 


\begin{tabular}{|c|c|c|c|c|c|c|c|c|c|c|c|}
\hline & & & & & & & CORTE & & & MINAÇÃO & \\
\hline & & & & & & Data & Pontuação & \%Total & Data & Pontuação & \% Total \\
\hline & & & & & & $10 / 05 / 2010$ & 870,4 & $86,3 \%$ & $10 / 05 / 2010$ & 1058,2 & $99,2 \%$ \\
\hline & & & & & & $\begin{array}{l}\text { Capacidade } \\
\text { programada } \\
\text { (por dia) }\end{array}$ & 1008,7 & & $\begin{array}{l}\text { Capacidade } \\
\text { programada } \\
\text { (por dia) }\end{array}$ & 1067,2 & \\
\hline & & & & & & $\begin{array}{c}\text { Takt time } \\
\text { (seg/ponto) }\end{array}$ & 80,3 & & $\begin{array}{c}\text { Takt time } \\
\text { (seg/ponto) }\end{array}$ & 75,9 & \\
\hline & & & & & & Turnos/Dia & 3 & & Turnos/Dia & 3 & \\
\hline & & & & & & Eficiência & $70 \%$ & & Eficiência & $80 \%$ & \\
\hline Pedido & Familia & $\begin{array}{l}\text { Quantidade } \\
\text { de peças }\end{array}$ & $\begin{array}{c}\text { Largura } \\
(\mathrm{mm})\end{array}$ & $\begin{array}{l}\text { Altura } \\
(\mathrm{mm})\end{array}$ & $\begin{array}{c}\text { Espessura } \\
(\mathrm{mm})\end{array}$ & & Pontuação & & & Pontuação & \\
\hline 223476 & Laminado & 130 & 1238 & 1512 & 10 & & 187,40 & & & 468,00 & \\
\hline 226453 & Laminado & 124 & 1238 & 1582 & 8 & & 188,78 & & & 421,60 & \\
\hline 227443 & Laminado & 26 & 1238 & 1336 & 10 & & 24,97 & & & 132,60 & \\
\hline 227443 & Laminado & 90 & 1000 & 900 & 8 & & 67,5 & & & 36,0 & \\
\hline 227443 & Laminado & 68 & 675 & 1221 & 8 & & 22,1 & & & 47,6 & \\
\hline 228765 & Laminado & 26 & 1238 & 2986 & 12 & & 39,0 & & & 62,4 & \\
\hline 228659 & Laminado & 78 & 1238 & 1586 & 10 & & 91,6 & & & 140,4 & \\
\hline 224560 & Laminado & 130 & 500 & 720 & 6 & & 65,0 & & & 52,0 & \\
\hline 225553 & Laminado & 92 & 1022 & 1450 & 12 & & 52,6 & & & 193,2 & \\
\hline 228989 & Temperado & 65 & 987 & 1034 & 8 & & 12,0 & & & 0,0 & \\
\hline 225654 & Serigrafado & 284 & 670 & 1240 & 10 & & 121,3 & & & 0,0 & \\
\hline 227121 & Temperado & 132 & 1350 & 780 & 10 & & 46,43 & & & 0,0 & \\
\hline 227663 & Cortado & 186 & 897 & 469 & 6 & & 46,50 & & & 0,0 & \\
\hline 228143 & Temperado & 197 & 1050 & 800 & 8 & & 49,25 & & & 0,0 & \\
\hline 229943 & Cortado & 135 & 690 & 500 & 6 & & 21,94 & & & 0,0 & \\
\hline 221045 & Cortado & 283 & 1230 & 980 & 5 & & 63,44 & & & 0,0 & \\
\hline 222543 & Serigrafado & 252 & 700 & 862 & 8 & & 40,95 & & & 0,0 & \\
\hline
\end{tabular}

Figura 38 - Programação do processo de Corte

As peças listadas na Figura 38 formam o conjunto Prog ${ }_{\mathrm{PUX}}$, que é formado por todas as peças programadas no processo puxador em um dia de produção.

Assim como no passo D.7, a frequiência de execução do passo D.8 é diária.

\section{Aplicação do Passo D.9}

O último passo do método proposto é disponibilizar a programação e nivelamento do processo puxador no chão de fábrica através de um quadro de nivelamento da produção.

$\mathrm{Na}$ aplicação realizada, o quadro de nivelamento presente no processo puxador apresenta a lista de ordens de produção que devem ser produzidas durante o dia programado, nos três turnos de produção, conforme apresentado na Figura 39. Nele, o programador preenche diariamente as informações sobre as ordens de produção como o número da ordem de produção, a família de produto, a quantidade de chapas que deveriam ser cortadas para concluir a ordem de produção e a pontuação referente a essa ordem de produção. Durante a produção, o operador do Corte aponta quais ordens de produção já foram cortadas. 


\begin{tabular}{|c|c|c|c|c|}
\hline \multicolumn{5}{|c|}{ Quata 17/05/2010 } \\
\hline OP & Família de Produto & $\begin{array}{c}\text { Quantidade } \\
\text { chapas }\end{array}$ & Pontuação & Situação \\
\hline 38142 & Laminado & 35 & 114,6 & Cortado \\
\hline 36712 & Laminado & 13 & 62,9 & \\
\hline 38102 & Laminado & 12 & 48,2 & \\
\hline 37484 & Laminado & 21 & 103,0 & \\
\hline 35645 & Laminado & 15 & 105,1 & \\
\hline 35423 & Monolitico & 22 & 58,7 & \\
\hline 34588 & Monolitico & 17 & 51,4 & \\
\hline 37981 & Monolitico & 10 & 90,2 & \\
\hline 38321 & Temperado obras & 20 & 69,1 & \\
\hline 37145 & Temperado obras & 21 & 62,5 & \\
\hline 35442 & Temperado obras & 13 & 42,8 & \\
\hline 37842 & Temperado seriado & 18 & 145,4 & \\
\hline 35909 & Temperado seriado & 10 & 90,8 & \\
\hline & & & & \\
\hline & & & & \\
\hline & & & & \\
\hline & & & & \\
\hline & & & & \\
\hline
\end{tabular}

Figura 39 - Quadro de programação do processo de Corte

Um sistema CONWIP foi utilizado para auxiliar o operador do Corte a evitar que haja processos clientes muito abastecidos enquanto outros processos clientes parando por falta de abastecimento. O processo de Corte fornece diretamente para quatro processos distintos: Laminação, Lapidação e Têmpera (para obras) e Têmpera (para produtos seriados). Foi definido para cada um dos processos clientes do Corte um número máximo de cartões. Para o processo de Laminação foram definidos 16 cartões, para o processo de Lapidação foram definidos 10 cartões, para o processo de Têmpera (para obras) foram definidos 8 cartões e para Têmpera (para produtos seriados) foram definidos 4 cartões.

Os cartões eram posicionados em um quadro próximo ao Corte onde era possível visualizar quais processos estavam menos abastecidos e o Corte analisava o quadro antes de decidir o que produzir, evitando, assim, que um processo estivesse muito abastecido enquanto outro estivesse sem peças para processar.

Assim que uma carreta (contenedor) de peças de cada uma das famílias era cortada, um cartão referente a este produto era retirado do quadro e anexado à peça, conforme Figura 40. Assim que o processo cliente processava o produto da carreta, o cartão era devolvido ao 
quadro do Corte através dos abastecedores responsáveis pela movimentação de peças pela fábrica.

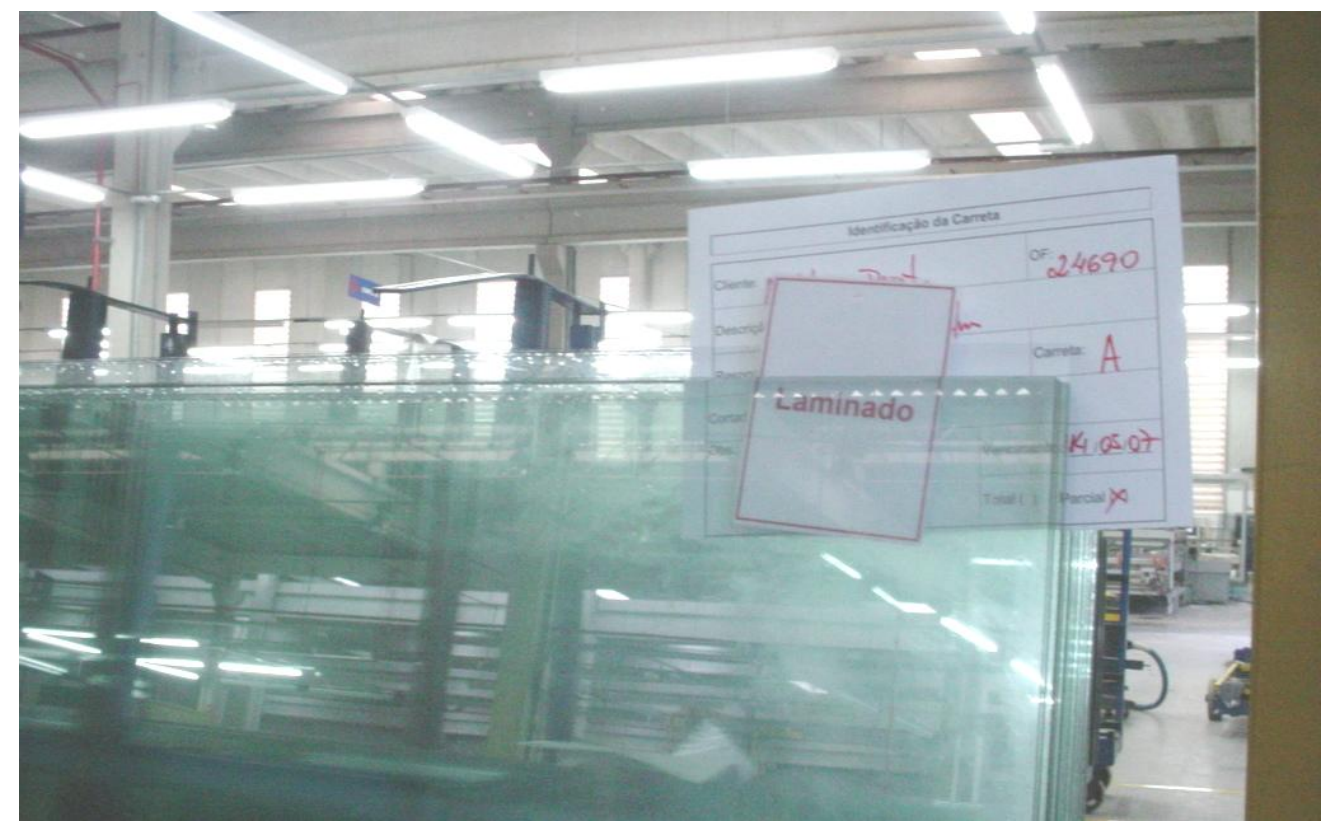

Figura 40 - Utilização do cartão no sistema CONWIP

Os operadores do Corte apontam a cada hora trabalhada a quantidade de pontos cortada durante o período em um formulário com o objetivo de acompanhar se o processo de Corte está conseguindo produzir a meta horária definida para o setor.

O passo D.9 é executado com freqüência diária, assim como a realização da programação da produção, que também acontece diariamente.

\subsection{Análise dos resultados}

O método aplicado na empresa estudada foi importante para implantar o conceito de programação e nivelamento em um único ponto do fluxo de valor, ou seja, no processo puxador.

O procedimento para programação e nivelamento do processo puxador foi aplicado passo a passo na empresa estudada. O último passo, de formalizar a programação da produção no heijunka box, foi aplicado de forma parcial, visto que apesar de a informação sobre a programação da produção ser passada aos operadores, algumas características de um quadro 
de nivelamento não foram atendidas, como uma gestão visual da situação da produção a qualquer momento, através da régua de tempo presente em alguns modelos de quadro de nivelamento, como o modelo apresentado por Tardin (2001).

A empresa optou por essa forma de passar a informação ao chão de fábrica por ser mais simplificada. Entretanto, essa forma será revista junto aos envolvidos e será proposta a implantação de um quadro de nivelamento que apresente mais funcionalidades que o sistema que foi implantado até o momento.

A implantação da nova sistemática de programação e nivelamento do processo puxador na empresa estudada ocorreu durante um período de, aproximadamente, 8 meses, desde a identificação da necessidade até a conclusão dos testes sobre a nova sistemática implantada.

Essa melhoria ocorreu em paralelo a outras melhorias implantadas durante o projeto de implantação de conceitos de Produção Enxuta na empresa. O projeto durou cerca de dois anos em toda a empresa e cerca de oito meses no processo de Laminação e trouxe resultados expressivos para a empresa.

Não é possível afirmar que o ganho obtido pela empresa foi referente apenas à implantação apresentada nesta aplicação, já que houve diversas implantações em paralelo na empresa. Também não é possível identificar claramente qual a participação de cada melhoria implantada na obtenção dos resultados apresentados.

A melhoria de produtividade no recurso de Laminação era um dos principais objetivos da empresa ao aplicar os conceitos de Produção Enxuta. A implantação da nova sistemática de programação e nivelamento do processo puxador impactou no aumento do volume produzido sem alterar a quantidade de operadores, pois evitou que o processo deixasse de produzir por não estar abastecido, seja por falta de programação no setor ou por priorizações equivocadas no setor do Corte, que aconteciam com certa frequiência.

Outra implantação significativa para o setor, e que impactou no aumento de produtividade do processo de Laminação foi a padronização de atividades dos operadores do processo.

Ambas as implantações, assim como as outras realizadas durante o projeto, foram realizadas através da metodologia de Evento Kaizen. 
Os ganhos apresentados adiante ocorreram sem acréscimo de operadores no processo de Laminação. Dessa forma, o aumento na produção média por turno trabalhado se reflete em aumento de produtividade do setor.

O Gráfico 3 mostra a evolução da produção em pontos nos turnos normais de produção (exceto turnos realizados com horas extras). As implantações citadas anteriormente ocorreram entre os meses de fevereiro e março.

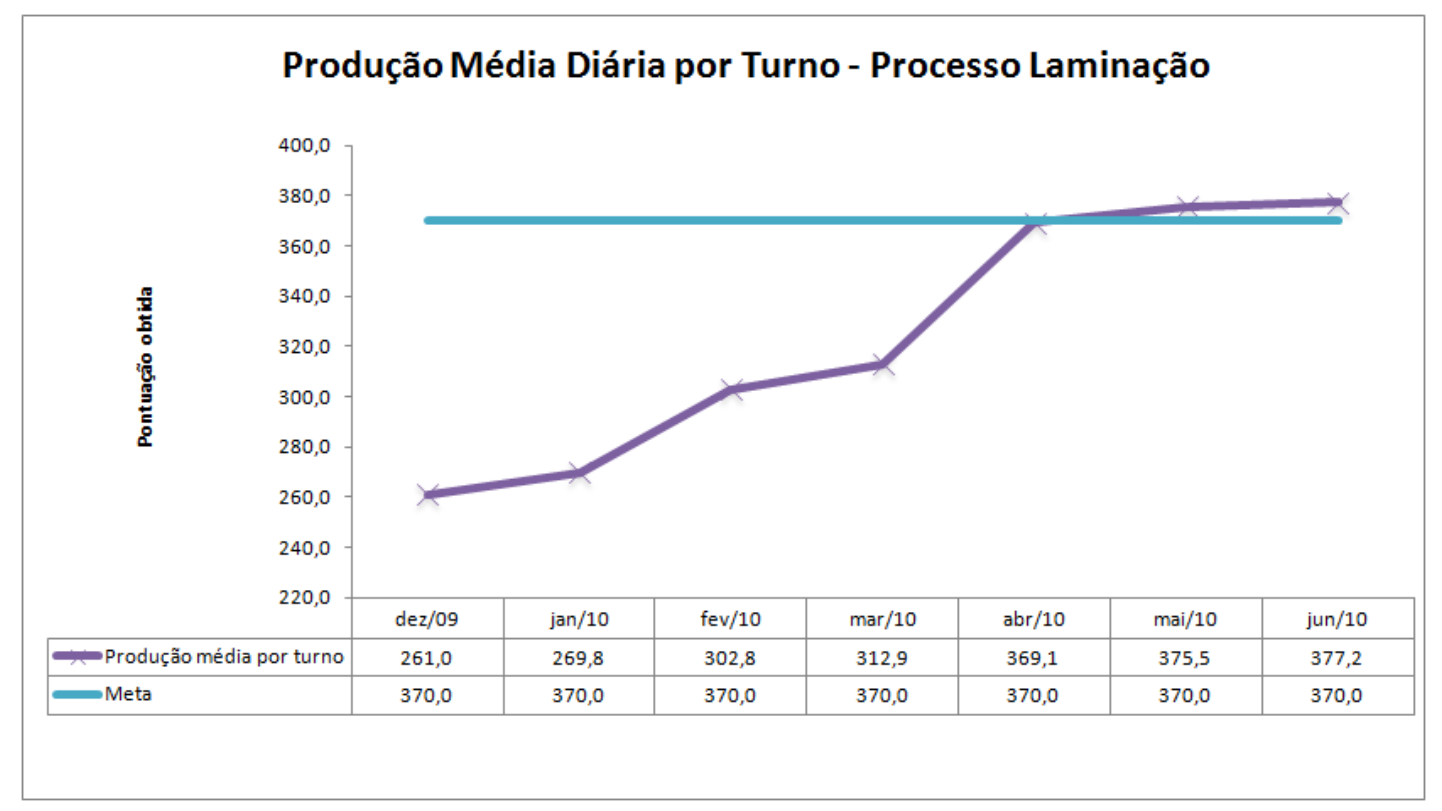

Gráfico 3 - Evolução da produção diária por turno no processo de Laminação

É importante salientar que a meta considerada é de 370 pontos por turno, porém a capacidade programada varia de acordo com a previsão de vendas e é ajustada mensalmente. Para facilitar a visualização foi considerado como meta de produção por turno o valor de 370 pontos.

É possível verificar no Gráfico 3, que o setor de Laminação conseguiu atingir com os turnos normais de trabalho a produção necessária para atender à demanda. Atingir uma produção maior do que a apresentada nos meses de abril a junho não foi desejável, visto que isso representaria uma superprodução, já que a capacidade programada é a quantidade de trabalho necessária para atender à demanda. 
Outros ganhos trazidos com a implantação do método foram a melhor visão da capacidade de produção, um procedimento definido de política de programação da produção e uma sistemática de levantamento de desvios da produção e rotina de análise e geração de plano de ação a partir dos dados levantados.

O aumento de produtividade conquistado através das implantações ocorreu devido a algumas ações, entre as quais é possível citar:

- Programação da ociosidade: o processo de Laminação não deixa de produzir por falta de peças devido à programação da produção;

- Controle da produção orientado pela produtividade: o processo de Laminação é controlado através de apontamentos periódicos da produtividade alcançada e as causas de desvios em relação à produtividade esperada;

- Padronização de atividades: as atividades para a laminação do vidro foram padronizadas. Dessa forma, a melhor forma de realizar a laminação do vidro foi validada e padronizada entre os turnos de produção;

- Sincronização das etapas produtivas: as etapas produzidas foram sincronizadas através do sistema CONWIP.

Durante a realização do projeto de implantação dos conceitos de Produção Enxuta algumas dificuldades foram encontradas pela equipe. A primeira delas foi a saída repentina de um dos integrantes da equipe interna da empresa responsável pela realização das implantações. Para solucionar este problemas, foi realizado um processo seletivo interno com pessoas interessadas em participar da equipe e, a partir do resultado desse processo seletivo, uma nova equipe foi formada.

Outra dificuldade encontrada foi o entendimento do conceito de pontos pelos operadores. Inicialmente, os operadores não conseguiam entender a importância de medir por pontos a produção, visto que a medição da produção por área produzida não apresentava acurácia. $\mathrm{O}$ controle da produção também não foi bem aceito pelos operadores já que não havia nenhum tipo de controle antes das implantações. A solução para estes problemas foi realizar treinamentos de conscientização e acompanhamento dos operadores. 


\section{CAPÍTULO 5-CONCLUSÃO}

Nesse capítulo serão apresentadas as principais conclusões desse trabalho, discutidas sobre o atendimento ao objetivo proposto e a elucidação às questões de pesquisa, além de propostas de trabalhos futuros.

Este trabalho teve o objetivo de apresentar um modelo de programação nivelada da produção para ambientes de produção enxuta para ETO que apresentem alta variedade de produtos e alta variação de tempos de ciclo. Pode-se afirmar que o trabalho aqui apresentado atingiu plenamente o objetivo proposto de apresentar o método e, posteriormente, ilustrar uma aplicação realizada do método.

A ilustração do método apresentada no Capítulo 4 deste trabalho foi específica sobre uma das quatro possibilidades de posicionamento do RRC. As outras três possibilidades não foram aplicadas e apresentadas neste trabalho. De qualquer forma, a aplicação em uma situação específica demonstra a relevância do assunto estudado.

O método proposto contempla quatro situações de posicionamento do processo RRC em relação ao processo puxador do fluxo de valor. Outras situações, não consideradas dentre as quatro apresentadas, podem ocorrer. Uma dessas situações é quando há processos puxadores distintos para diferentes famílias de produto que compartilham o mesmo fluxo de valor. Essa situação citada e outras que possam acontecer não foram contempladas no método por serem bastante específicas e podem ser objeto de estudos futuros.

As questões de pesquisa apresentadas no Capítulo 1 desse trabalho estão listadas adiante:

- Como definir takt time para ambientes de alta variedade de produtos, onde ocorrem variações nos tempos de ciclo? 
- Como deve ser realizada a programação nivelada da produção para ambientes com alta variação de tempo de ciclo?

- Existe na literatura um método para nivelamento da produção para ambiente ETO com alta variedade de produto e alta variação de tempos de ciclo?

Pode-se considerar que as questões de pesquisa definidas foram devidamente respondidas.

A primeira delas foi discutida durante a revisão da literatura apresentada no Capítulo 2 deste trabalho, onde foram apresentadas as dificuldades de utilizar o conceito de takt time em ambientes com alta variação de tempo de ciclo e uma forma de adaptar o conceito a esse tipo de situação.

A segunda questão também foi discutida durante a revisão bibliográfica, com a apresentação de um método encontrado na literatura sobre como realizar a programação nivelada da produção para ambientes com alta variação de tempos de ciclo. Importante salientar que possam existir outros métodos não reproduzidos em trabalhos acadêmicos e não encontrados durante a revisão da literatura sobre o assunto.

Por fim, a terceira questão de pesquisa é sobre a identificação, na literatura, de um método que atenda a situação apresentada, ou seja, um ambiente ETO com alta variedade de produtos e alta variação de tempos de ciclo. A característica principal do ambiente ETO considerada é o desconhecimento dos tempos de ciclo dos produtos já que o produto é único e não foi produzido anteriormente. Essa questão foi respondida em partes, já que foi encontrado na literatura um método para estimativa de tempos de ciclo em ambientes ETO e métodos para ambientes com alta variedade de produtos e alta variação de tempos de ciclo. Porém, não foi encontrado durante a revisão da literatura um método que contemplasse todas as características da situação estudada.

A aplicação apresentada pode ser considerada uma ilustração do método e não determina uma validação inquestionável do método proposto. Porém, pode-se afirmar que a ilustração realizada mostra a sua aplicabilidade, já que sua aplicação trouxe resultados satisfatórios para a empresa.

Dentre os benefícios que a aplicação do método apresentou, é possível citar: 
- melhor visão da capacidade de produção: a estimativa de tempos de ciclo permitiu que os gestores visualizassem de forma mais precisa a capacidade dos processos;

- política de programação da produção com procedimento definido: os passos para determinar a programação da produção foram definidos e validados com todos os envolvidos;

- levantamento de desvios de produção e rotina de análise destes dados e geração de plano de ação para os problemas encontrados: somente com uma visão clara sobre capacidade e metas de produção foi possível identificar desvios de produção e apontá-los. No caso apresentado, foi criada uma rotina, com envolvimento de toda a equipe, desde operadores até o gerente industrial, para análise e definição de ações com o objetivo de reduzir possíveis desvios de produção.

O método proposto pela autora pode servir de base para alguns trabalhos futuros tanto no ambiente acadêmico quanto profissional. A primeira sugestão de trabalhos futuros é a realização de casos ilustrativos para as demais situações apresentadas pelo método proposto.

Outra sugestão para realização de trabalhos futuros é o estudo mais abrangente do método considerando situações de posicionamento do RRC no fluxo de valor que não foram contempladas no método proposto. Entre elas é possível citar a situação quando há processos puxadores distintos para diferentes famílias de produto que compartilham o mesmo fluxo de valor.

Assim, pode-se considerar que o tema estudado neste trabalho é bastante relevante aos cenários encontrados nas indústrias atualmente. Empresas com tipologia de produção ETO representam uma parcela significativa nas indústrias relacionadas à construção civil e bens de capital, entre outros segmentos da indústria.

Considerando que não foi encontrado na literatura estudada nenhum método semelhante, o método aqui apresentado pode ser considerado uma contribuição importante para o cenário de aplicação dos conceitos de Produção Enxuta em ambientes com tipologia de produção ETO. 


\section{REFERENNCIAS}

ALMEIDA, J. A. R. (2006). Estudo sobre a aplicabilidade de princípios da produção enxuta em processos de apoio à produção. Trabalho de Conclusão de Curso. Escola de Engenharia de São Carlos, Universidade de São Paulo. São Carlos.

ALVAREZ, R. R.; ANTUNES, J. A. V. Takt-Time: Conceitos e Contextualização dentro do sistema Toyota de produção. Gestão \& Produção, v.8, n.1, p.1-18, abr.2001.

ARAUJO, C. A. C. (2004). Desenvolvimento e aplicação de um método para implementação de sistemas de produção enxuta utilizando os processos de raciocínio da Teoria das Restrições e o mapeamento do fluxo de valor. Dissertação de Mestrado. Escola de Engenharia de São Carlos, Universidade de São Paulo. São Carlos.

ARAUJO, C. A. C.; RENTES, A. F. (2004). Aplicação da Teoria das Restrições na criação e implementação de um modelo de medição de desempenho atrelado à remuneração. Encontro Nacional de Engenharia de Produção (ENEGEP 2004). Florianópolis.

ARAUJO, C. A. C.; RENTES, A. F. (2006). A metodologia kaizen na condução de processos de mudança em sistemas de produção enxuta. Revista Gestão Industrial, v.2, n.2, p.126-135, 2006.

ARAUJO, L. E. D. (2009). Nivelamento de Capacidade de Produção utilizando Quadros Heijunka em Sistemas Híbridos de Coordenação de Ordens de Produção. Dissertação (Mestrado). Escola de Engenharia de São Carlos, Universidade de São Paulo. São Carlos.

BEKER, J. C.; GUTIERREZ, R. H. (2007). Planejamento e controle de produção: Estratégia qualificadora para empresas de manufatura resistirem no mercado. SEGeT - Simpósio de Excelência em Gestão e Tecnologia. 
BOKHORST, J. A. C.; SLOMP, J. (2007). Towards takt time controlled production units in low volume high variety environments. University of Groningen.

BOKHORST, J. A. C.; SLOMP, J.; GERMS, R. (2009). A lean production control system for high-variety/low-volume environments: a case study implementation. Production Planning \& Control, v.20, n.7, p. 586-595, oct. 2009.

CORBETT NETO, T. (1997). Contabilidade de ganhos: a nova contabilidade gerencial de acordo com a Teoria das Restrições. São Paulo: Nobel.

CORRÊA, H. L.; GIANESI, I. G. N. (1993). Just in Time, MRP II e OPT: Um enfoque estratégico. 2. ed. São Paulo: Atlas.

CORRÊA, H. L.; GIANESI, I. G. N.; CAON, M. (2001). Planejamento, Programação e Controle da Produção: MRP II/ERP: Conceitos, Uso e Implantação. 4. ed. São Paulo: Atlas, 2001.

DAVIS, M. M.; AQUILANO, N. J.; CHASE, R. B. (1999). Fundamentos da Administração da Produção. 3. ed. Porto Alegre: Artmed.

DUGAN, K. J. (2002). Creating mixed model value stream: Practical lean techniques for building to demand. New York.

FRANCISCHINI, P.G. Necessidades de Aplicação de Ferramentas de Melhoria deProdutividade em Micro e Pequenas Empresas. E.P.U.S.P. São Paulo.

FUNARO, V. M. B. O. et al.. (2004). Diretrizes para apresentação de dissertações e teses da USP: documento eletrônico e impresso. Sistema Integrado de Bibliotecas. Universidade de São Paulo. São Paulo.

FURMANS, K. (2005). Models of heijunka-levelled kanban-systems. IFL, University of Karlsruhe (TH).

GAITHER, N.; FRAZIER, G. (2002). Administração da Produção e Operações. 8. ed. São Paulo: Pioneira Thomson Learning. 
GHINATO, P. (2005). Sistema Toyota de Produção: Mais do que simplesmente Just-in-time. Editora da UCS, Caxias do Sul, RS.

GIL, A. C. (1991). Como elaborar projetos de pesquisa. $3^{\text {a }}$ edição. São Paulo: Atlas.

GOLDRATT, E. A. (1991). A síndrome do palheiro: garimpando informações num oceano de dados. São Paulo: IMAM.

HINES, P.; TAYLOR, D. (2000). Going lean: a guide to implementation. Cardiff: Lean Enterprise Research Center.

HOPP, W. J.; SPEARMAN, M. L. (1996). Factory Phisics: Foundations of Manufacturing Management. The McGraw-Hill Companies.

HOPP, E. J.; SPEARMAN, M. L. (2004). To pull or not to pull: What is the question?. Manufacturing \& Service Operations Management v.6, n.2, p. 133-148, spring 2004.

HÜTTMEIR, A. et al. (2006). Trading off between heijunka and just-in-sequence. Int. J. Production Economics, n.118, p.501-507, jan. 2009.

JINA, J.; BHATTACHARYA, A. K.; WALTON, A. D. (1995). Applying lean principles for product variety and low volumes: some issues and propositions. Logistics Information Management, v.10, n.1, p.5-13, 1997.

JONES, D. T. (2006). Heijunka: Leveling Production. Manufacturing Engineering, v. 137, n. 2, ago. 2006.

LAGE JR., M.; GODINHO FILHO, M. (2006). A utilização do sistema kanban frente às novas condições do ambiente competitivo. XIII Simpep - Bauru, São Paulo, Brasil, nov. 2006.

LAURINDO, F. J. B.; MESQUITA, M. A. (2000). Material Requirements Planning: 25 anos de história - uma revisão do passado e prospecção do futuro. Gestão \& Produção v.7, n.3, p. 320-337, dez. 2000. 
LEAN ENTERPRISE INSTITUTE (2007). Léxico lean - glossário ilustrado para praticantes do pensamento lean. v.2.0. São Paulo: Lean Institute Brasil.

LEITÃO, G.; BENAMOR, I.; MECENA, S. (2007). Metodologia de estudo de tempos para implantação de sistema ERP: estudo de caso em indústria de serviços altamente especializada. XXVII Encontro Nacional de Engenharia de Produção (ENEGEP), Foz do Iguaçu, out. 2007.

LEWIS, M. A. Lean Production and sustainable competitive advantage. International Journal of Operations \& Production Management, v. 20, n. 8, p. 959-978, 2000.

LIKER, J. K. (2004). O Modelo Toyota: 14 princípios de gestão do maior fabricante do mundo. Tradução de Lene Belon Ribeiro. Porto Alegre: Bookman.

MANOS, A. (2007). The benefits of kaizen and kaizen events. American Society for Quality (ASQ).

MARTINS, R. A. (1993). Flexibilidade e Integração no novo paradigma produtivo mundial : estudos de casos. Dissertação de Mestrado. Escola de Engenharia de São Carlos, Universidade de São Paulo. São Carlos.

MCBRIDE, D. (2004). Heijunka: Leveling the Load. Disponível em: <http://www. reliableplant.com/Read/14245/heijunka>. Acesso em: 15 Fev. 2010.

MENEGON, D.; NAZARENO, R. R.; RENTES, A. F. (2003). Relacionamento entre desperdícios e técnicas a serem adotadas em um Sistema de Produção Enxuta. XXIII Encontro Nacional de Engenharia de Produção. Ouro Preto, MG.

MOURA JR., A. N. C. (1996). Novas tecnologias e sistemas de administração da produção: Análise do grau de integração e informatização nas empresas catarinenses. Dissertação (Mestrado). Universidade Federal de Santa Catarina, Florianópolis.

NAZARENO, R. R. (2003). Desenvolvimento e aplicação de um método para implementação de sistemas de produção enxuta. Dissertação (Mestrado). Escola de Engenharia de São Carlos, Universidade de São Paulo. São Carlos. 
NAZARENO, R. R. (2008). Desenvolvimento de Sistemas Híbridos de Planejamento e Programação da Produção com foco na implantação de manufatura enxuta. Tese (Doutorado). Escola de Engenharia de São Carlos, Universidade de São Paulo. São Carlos.

NIIMI, A. (2004). Sobre o Nivelamento (Heijunka). Lean Institute Brasil. Disponível em: < http://www.docstoc.com/docs/30186065/1-14-Sobre-o-Nivelamento-\%28heijunka\%29Adaptado-de-discurso-proferido>. Acesso em: 1 Dez. 2009.

OHNO, T. (1988). O Sistema Toyota de Produção: além da produção em larga escala. Porto Alegre: Bookman, 1997.

PERIN, P. C. (2005). Metodologia de padronização de uma célula de fabricação e de montagem, integrando ferramentas de produção enxuta. Dissertação (Mestrado) - Escola de Engenharia de São Carlos, Universidade de São Paulo, São Carlos.

RENTES, A. F. (2000). TransMeth - Proposta de uma Metodologia para Condução de Processos de Transformação de Empresas. Tese de Livre-Docência. Escola de Engenharia de São Carlos, Universidade de São Paulo, São Carlos.

RENTES, A. F. (2005). Lean production for enterprises with high variety of products. International Conference on Flexible Automation and Intelligent Manufacturing, Bilbao, v.1, p. 334-339, 2005.

RENTES, A. F. (2009). Apresentação sobre Conceitos de Produção Enxuta e Mapeamento de Fluxo de Valor. Encontro de Especialistas Hominiss.

RONEN, B.; STARR, M. K. (1990) Synchronized manufacturing as in OPT: from practice to theory. Tel Aviv, Israel and Columbia University. New York, USA.

ROTARU, A. (2008). All about takt time. Management and Technological Engineering, v.7, 2008.

ROTHER, M.; SHOOK, J. (1999) Aprendendo a Enxergar - Mapeando o fluxo de valor para agregar valor e eliminar o desperdício. São Paulo, SP. Lean Institute Brasil. 
SALMAN, M. R. et al.. (2009). Applying lean principles to production scheduling. Irish Research Council for Science, Engineering and Technology (IRCSET).

SALOMON, V. A. P. (2004). Desempenho da modelagem do auxílio à decisão por múltiplos critérios na análise do planejamento e controle da produção. Tese (Doutorado). Universidade de São Paulo. São Paulo.

SCARPELLI, M. (2006). Sistemas de produção agroalimentar: arquitetura para as funções de planejamento e controle da produção. Tese (Doutorado). Universidade Federal de São Carlos. São Carlos.

SHINGO, S. (1996). O sistema Toyota de produção do ponto de vista da engenharia de produção. Porto Alegre: Bookman.

SILVA, E. L.; MENEZES, E. M. (2005). Metodologia da Pesquisa e Elaboração da Dissertação. $4^{\mathrm{a}}$. ed. rev. atual., UFSC, Florianópolis, SC.

SLACK, N. et al.. (1999). Administração da Produção. São Paulo: Atlas.

SMALlEY, A. (2004). Criando o Sistema Puxado Nivelado: um guia para aperfeiçoamento de sistemas lean de produção, voltado para profissionais de planejamento, operações, controle e engenharia. Brookline: Lean Enterprise Institute.

SPEARMAN, M. L.; ZAZANIS, M. A. (1992). Push and Pull Production Systems: Issues and Comparisons. Operational Research, v. 40, p. 521-532.

STEFANELLI, P. (2007). Utilização da Contabilidade dos Ganhos como Ferramenta para a Tomada de Decisão em um Ambiente com Aplicação dos Conceitos de Produção Enxuta. Trabalho de Conclusão de Curso. Escola de Engenharia de São Carlos, Universidade de São Paulo. São Carlos.

SOUZA, F. B. (2005). Do OPT à Teoria das Restrições: Avanços e mitos. Prod. 2005, vol. 15, n. 2, pp. 184-197. São Paulo. 
TARDIN, G. G. (2001). O Sistema Puxado e o Nivelamento da Produção. Dissertação (Mestrado). Faculdade de Engenharia Mecânica, Universidade Estadual de Campinas. Campinas.

TARDIN, G. G.; LIMA, P. C. (2000). O papel de um quadro de nivelamento de produção na produção puxada: um estudo de caso. Disponível em: <http://www.abepro.org.br/biblioteca/ENEGEP2000_E0097.PDF>. Acessado em: 16 de junho de 2010.

TAPPING, D.; LUYSTER, T.; SHUKER, T. (2002). Value Stream Management: Eight Steps to Planning, Mapping and Sustaining Lean Improvements. Productivity Press, New York, USA.

VILLACRESES, K. F. B. (2003). A $m$ hodology for identifying and eliminating waste in office environment. $\mathrm{PhD}$ thesis, The University of Texas at Arlington, USA.

VOLLMAN, T. E.; BERRY, W. L.; WHIBARK, D. C.(1997). Manufacturing Planning and Control Systems. Irwin McGraw-Hill.

WOMACK, J. P.; JONES, D. T. (1996). Lean Thinking - banish waste and create wealth in your corporation. New York: Simon \& Schuster.

WOMACK, J. P.; JONES, D. T.; ROOS, D. (1992). A máquina que mudou o mundo. Rio de Janeiro: Campus. 